\title{
INSTITUTIONAL INVESTORS IN CHINA: CORPORATE GOVERNANCE AND POLICY CHANNELING IN THE MARKET WITHIN THE STATE
}

\author{
Lin Lin \& Dan W. Puchniak*
}

The extraordinary rise of China's economy has made understanding Chinese corporate governance an issue of global importance. A rich literature has developed analyzing the Chinese Communist Party's (CCP) role as China's largest controlling shareholder and the impact that this has on Chinese corporate governance. However, the CCP's role as the architect-and direct and indirect controller-of institutional investors in China has been largely overlooked in the legal literature.

This Article aims to take the first step in filling this gap in the literature by drawing on Chinese sources and fresh hand-collected empirical, interview, and case study evidence to analyze the meteoric rise of institutional investors in China. It provides a taxonomy of institutional investors in China and reveals how the market for institutional investors has grown and has become increasingly "atomized" as different types of institutional investors have proliferated. The Article reveals how the CCP has actively and gradually promoted the growth of domestic institutional investors, in terms of types and size, through the relaxation of policies and law reforms to improve corporate governance and stabilize the stock market, while limiting the influence of foreign institutional investors. It further analyzes all the Activist Campaigns undertaken by institutional investors in China and maps the network of government

\footnotetext{
${ }^{*}$ Lin Lin and Dan W. Puchniak are Associate Professors in the Faculty of Law at the National University of Singapore (NUS Law). We are grateful to the NUS Law Centre for Asian Legal Studies (CALS) and the NUS EW Barker Centre for Law \& Business (EWBCLB) for funding this research project. We thank the interviewees (including a partner of the Global Law Office (Beijing), a legal counsel of DBS Securities (China), a legal counsel of HSBC (Chongqing), a senior manager of CMS (Shanghai), an investment manager of GF Securities (Guangzhou), an investment manager of CICC (Shenzhen), a legal counsel of CICC (Singapore), a legal officer of SAFE, a financial adviser of COFCO (Guangzhou), and a partner of DeHeng Law Offices (Chongqing) for sharing their insights with us. We are grateful to Pangyue Cheng, Tami Groswald, Robin Hui Huang, Michael Klausner, Guo Li, Yu-Hsin Lin, Curtis Milhaupt, Mariana Pargendler, Teemu Ruskola, Holger Spamann, Hans Tjio, Yongnian Zheng, Zhong Jinghui and Alex Zhou for feedback on earlier drafts of this Article and to Jordan Ng Qi Le, Ivan Tan Ren Yi, and Zhu Xuan at NUS Law for their exceptional work as research assistants. We are also grateful to the editorial team of the Columbia Journal of Asian Law who did an exceptional job editing this Article. Any errors remain our own.
} 
bodies, regulations, and tactics that the CCP has developed to directly and indirectly control State-Owned Institutional Investors (SOIIs) and Private-Owned Institutional Investors (POIIs) for the purpose of policy channeling.

This Article concludes by taking a step back and briefly considering what this examination of institutional investors tells us about China's unique form of capitalism and system of corporate governance. It suggests that the rise of institutional investors in China has been strategically developed in a way to reinforce the CCP's ultimate control over the financial system. However, contrary to what some conceptions of "state capitalism" may suggest, the CCP does not micro-manage institutional investors on a day-to-day basis. Rather, institutional investors normally function according to free-market forces and increasingly perform an important corporate governance role-with the CCP using its policy channeling in a targeted way to stabilize the market in times of crisis, execute important legal and market reforms, and to maintain calm in society during critical political events: what this Article termed as the "market within the state" for institutional investors in China.

Keywords: Institutional investors, Policy channeling, Minority Shareholder, Shareholder activism, Corporate governance, Market within the state 


\section{TABLE OF CONTENTS}

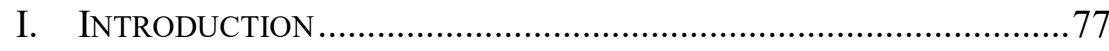

II. THE RISE OF INSTITUTIONAL INVESTORS IN CHINA - A

REMARKABLE, YET OVERLOOKED, HISTORY …................................. 84

A. Institutional Investors in China Can No Longer Be Ignored .. 84

B. Foreign Institutional Investors: A Small, But Growing, Piece of the Taxonomy …................................................................... 90

C. Domestic Institutional Investors: The Core of the Taxonomy 95

III. FILLING THE GAP IN THE LEGAL LITERATURE ON INSTITUTIONAL INVESTORS IN CHINA: EMPIRICAL RESEARCH AND ACTIVIST

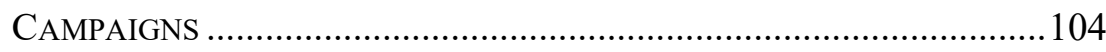

A. Illuminating the Gap in the Legal Literature ...................... 104

B. An Analysis of the Existing Empirical Research..................105

C. Activist Campaigns: How Institutional Investors as Minority

Shareholders Impact Corporate Governance in China .............. 114

IV. The DUAL Roles OF InSTITUTIONAL INVESTORS IN CHINA:

CORPORATE GOVERNANCE AND POLICY CHANNELING ......................119

A.Illuminating the CCPs Targeted Use of Policy Channeling in an Otherwise Free-Market. 119

B. Illuminating, Classifying, and Mapping the CCP's Mechanisms for Policy Channeling. 120

C. Day-to-Day Corporate Governance Function of Institutional

Investors in China

V. InSTITUTIONAL InVESTORS In CHINA: THE MARKET Within THE

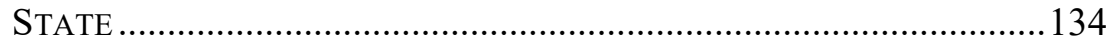

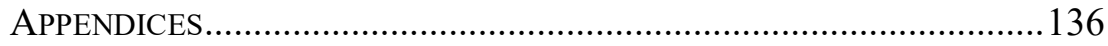

Appendix 1: Legal Developments and the Government's Role in Developing Institutional Investors in China 1978-2020............136

Appendix 2: Representative Activism Cases by Institutional Investors in China (1994-Present) 


\section{INTRODUCTION}

Two decades ago, the United Sates had almost twenty times as many Fortune Global 500 Companies as China. ${ }^{1}$ Today, the number of Fortune Global 500 Companies in China (124) has surpassed the United States $(121){ }^{2}$ China's listed companies are leaders in many of the world's most important industries, a fact that was unthinkable at the dawn of the new millennium. ${ }^{3}$ China now has the world's largest market for initial public offerings ${ }^{4}$ and the world's second largest stock market, which has grown five-fold in the past decade. ${ }^{5}$

For corporate law and governance scholars, even more surprising than China's economic miracle, is the central role the

${ }^{1}$ In 2000, China had 10 Fortune 500 Companies as compared to the USA's 179, see Scott Kennedy, The Biggest But Not the Strongest: China's Place in the Fortune Global 500, CTR. FOR STRATEGIC \& INT'L STUD. (Aug. 18, 2020), https:/www.csis.org/blogs/trustee-china-hand/biggest-not-strongest-chinas-placefortune-global-500.

${ }^{2}$ Alan Murray \& David Meyer, The Fortune Global 500 is now more Chinese than American, FORTUNE (Aug. 10, 2020), https://fortune.com/2020/08/10/fortuneglobal-500-china-rise-ceo-daily/.

${ }^{3}$ Chinese listed companies lead the world in industries such as pharmaceuticals, solar panels and online payment systems, see A Rising Star: China's pharmaceuticals industry is growing up, THE ECONOMIST (Sept. 28, 2019), https://www.economist.com/business/2019/09/28/chinas-pharmaceuticals-industryis-growing-up (Pharmaceuticals); Yukinori Hanada, China's solar panel markers top global field but challenges loom, NIKKEI ASIAN REVIEW (July 31, 2019), https://asia.nikkei.com/Business/Business-trends/China-s-solar-panel-makers-topglobal-field-but-challenges-loom (Solar panels); Wang Yue, \$7.6 Trillion Online Payments Market Is No Longer Enough For Jack Ma's Ant Financial, FORBES (Jan. 17, 2020), https://www.forbes.com/sites/ywang/2020/01/17/ant-financial-isshifting-away-from-chinas-76-trillion-online-payments-market/?sh=37563bda45b5 (Online payment systems).

${ }^{4}$ Laure He, Shanghai could be the world's biggest IPO market this year. Holding the title will be tough, CNN Business (Nov. 1, 2020), https:/edition.cnn.com/2020/10/31/investing/china-markets-ipo-intl-

hnk/index.html; Evelyn Cheng, Chinese Companies are leading the global IPO rush amid a 'flight from uncertainty', CNBC (Oct. 27, 2020), https://www.cnbc.com/2020/10/27/chinese-companies-are-leading-the-global-iporush-amid-a-flight-from-uncertainty.html; Georgina Lee, Shanghai overtakes Hong Kong as world's top IPO destination but mega deals waiting in wings will shake up full-year rankings, SOUTH CHINA MORNING POST (Mar. 31, 2020), https:/www.scmp.com/business/banking-finance/article/3077611/shanghaiovertakes-hong-kong-worlds-top-ipo-destination.

${ }^{5}$ The rise of China and fivefold growth of its stock market over the past decade have fueled a growing literature on this market in financial economics. See Jennifer N. Carpenter \& Robert F. Whitelaw, The Development of China's Stock Market and Stakes for the Global Economy, 9 AnN. REV. FIN. ECON. 233 (2017); See more recently Hudson Lockett, China's stock market value hits record high of more than $\$ 10$ tn, FinANCIAL TIMES (Oct. 14, 2020), https:/www.ft.com/content/7e2d1cae8033-45b1-811c-bc7d4a413e33 (confirming second largest stock market). 
Chinese government has played in achieving it. Before China's rise, the idea that a government could play the role of the most important shareholder in a $21^{\text {st }}$ century world-class corporation-let alone in a multitude of listed corporations at the core of the greatest economic miracle of our time-was an anathema. ${ }^{6}$ Yet, today, the Chinese government is by far the largest controlling shareholder in the Chinese stock market. ${ }^{7}$ Indeed, it is the largest controlling shareholder in the world. ${ }^{8}$

The foundation of the corporate governance system that led to the Chinese government's rise as the world's most powerful shareholder is now aptly described as "corporatization without privatization." Starting in the 1990s, a vast array of businesses that were run as units of the government were transformed into companies under the new PRC Company Law. ${ }^{10}$ These companies, with boards of directors and shareholders, were then listed on the Chinese stock market. Importantly, however, the government maintained-and still maintains - a controlling equity interest in its listed State-Owned Enterprises (SOEs). ${ }^{11}$ This system of equity finance has become

${ }^{6}$ Henry Hansmann \& Reinier Kraakman, The End of History for Corporate Law, 89 GEO. L. J. 439, 446 (2001); Tan Cheng Han et al., State-Owned Enterprises in Singapore: Historical Insights into a Potential Model for Reform, 28 ColuM. J. Asian. L. 61, 61 (2015); Curtis J. Milhaupt, The State as Owner - China's Experience, 36 OXF. REV. ECON. POL'Y 362, 362 (2020), https://academic.oup.com/oxrep/article-abstract/36/2/362/5813051.

7 Li-Wen Lin \& Curtis J. Milhaupt, We Are the (National) Champions: Understanding the Mechanisms of State Capitalism in China, 65 STAN. L. REV. 697, 700 (2013); Curtis J. Milhaupt \& Wentong Zheng, Beyond Ownership: State Capitalism and the Chinese Firm, 103 GEO. L. J. 665, 676 (Mar. 2015).

${ }^{8}$ Lin \& Milhaupt, supra note 7, at 700; Milhaupt \& Zheng, supra note 7, at 676 (CCP is the largest controlling shareholder in the world).

${ }^{9}$ Nicholas Howson, Protecting the State from Itself? Regulatory Interventions in Corporate Governance and the Financing of China's 'State Capitalism', in REgulating THE Visible HAND?: The Institutional IMPlications of Chinese State Capitalism 49, 51-52 (Benjamin L. Liebman \& Curtis J. Milhaupt eds., 2015).

${ }^{10}$ Howson, supra note 9, at 51-52; Jiangyu Wang \& Tan Cheng-Han, Mixed Ownership Reform and Corporate governance in China's State-Owned Enterprises, 53 VAND. J. TRANSNAT'L L. 1055 (2020).

11 'SOEs' in this article include: (1) enterprises in which government agencies own $100 \%$ of the shares (wholly state-owned enterprises), and enterprises in which government agencies and the wholly state-owned enterprises directly or indirectly own in aggregate $100 \%$ of the shares; (2) enterprises in which government agencies and the enterprises described in paragraph (1), individually or jointly, own in aggregate more than $50 \%$ of the shares and in which one of them is the largest shareholder; (3) subsidiaries in which an enterprise described in paragraphs (1) and (2) own more than $50 \%$ of the shares; and (4) enterprises in which a government agencies or an enterprise described in paragraphs (1) and (2) owns less than $50 \%$ of the shares, but is the largest shareholder, and is able to exercise effective domination 
known as mixed-ownership, as SOEs shares are split between the government as the (insider) controlling shareholder and (ostensibly, outsider) minority shareholders. ${ }^{12}$

There is a rich literature analyzing the government's role as China's largest controlling shareholder and the unique agency problems that flow from it. ${ }^{13}$ This research provides valuable insights into how the CCP has used the government's controlling shareholder power and other idiosyncratic governance mechanisms - such as Party Committees (dang wei hui) - to play a central role as a corporate governance insider in listed SOEs and even in many Private-Owned Enterprises (POEs).${ }^{14}$ However, the CCP's role as the architect-and direct and indirect controller - of institutional investors in China has remained underexplored, and is often entirely ignored. ${ }^{15}$

through shareholders' agreements, articles of association, board resolutions or other arrangements. See Qiye Guoyou Zichan Jiaoyi Jiandu Guanli Banfa (企业国有资产 交易监督管理办法) [Measures for the Supervision and Administration of the Transactions of State-Owned Assets of Enterprises] (promulgated by the Stateowned Assets Supervision and Administration Commission (SASAC) and Ministry Of Finance (MOF), Jun. 24, 2016, effective June 24, 2016) Art 4, available at http://lawinfochina.com/display.aspx?id=26008\&lib=law\&EncodingName=big5.

${ }^{12}$ Howson, supra note 9, at 51-52; Milhaupt, supra note 6; Wang \& Tan, supra note 10, at 1062-64.

${ }^{13}$ Id.; Lauren Yu-Hsin Lin, Institutionalizing Political Influence in Business: PartyBuilding and Insider Control in Chinese State-Owned Enterprises, 45 VT. L. REV. 437 (2021); John Zhuang Liu and Angela Huyue Zhang, Ownership and Political Control: Evidence from Charter Amendments, 60 INT'L REV. L. \& ECON. 105853 (2019); Lauren Yu-Hsin Lin and Yun-chien Chang, Do State-Owned Enterprises Have Worse Corporate Governance? An Empirical Study of Corporate Practices in China, EUR. BuS. ORG. L. REV. (forthcoming 2021); Wang \& Tan, supra note 10; Jiangyu Wang, The Political Logic of Corporate Governance in China's State-owned Enterprises, 47 CORNELL INT'L L.J. 631 (2014).

${ }^{14}$ Wang \& Tan, supra note 10, at 1094; Lauren Yu-Hsin Lin \& Curtis J. Milhaupt, Party Building or Noisy Signaling? The Contours of Political Conformity in Chinese Corporate Governance, at 3 (EGCI Law Working Paper No. 493/2020) (SOEs are now expected to expressly give the party's leadership and party committees formal legal status inside the company).

${ }^{15}$ This suggests a lack of awareness of the role of institutional investors in China. See Wang \& Tan, supra note 10, at 1106 (explains that strategic investors, who themselves have strong links to the party, play the role of supervising the board in China rather than institutional investors); Tamar Groswald Ozery, Minority Public Shareholders in China's Concentrated Capital Markets-A New Paradigm?, 30 COLUM. J. Asian L. 1, 28-30 (2016) (several market conditions such as the strict regimentation of institutional services where they only have limited investment choices, the short term investment horizon, and the lack of skillfulness of institutional investors have limited the ability of institutional investors to monitor and meaningfully participate in firms' governance in China); Howson, supra note 9, at 53-54 (there is nothing in the law that requires the controlling state actor to take into account the interests of the minority, much less the role of the minority institutional investor to monitor and participate in the firms' governance in China); Milhaupt, 
This lack of focus on institutional investors in Chinese corporate governance may have made sense two decades ago. At that time, in listed Chinese companies, institutional investors' shareholdings were miniscule, ${ }^{16}$ the CCP had an iron grip on corporate governance through the government's non-tradable controlling block shareholdings, ${ }^{17}$ and stringent caps on foreign institutional investor shareholdings rendered them negligible. ${ }^{18}$ All of these facts are relics of a bygone era.

The most recent statistics on China's shareholder landscape reveal that institutional investors now hold $18.7 \%$ of China's A-Shares market capitalization - almost double the percentage they held in 2014 and over ten times the amount in $2003 .{ }^{19}$ Institutional investors now account for almost half of the free float of shares in A-Shares companies, more than a ninefold increase since 2007-making institutional investors China's most important minority shareholders. ${ }^{20}$ At the end of 2019, the assets under management by institutional investors in China reached US\$16 trillion - a tenfold increase over the past 10 years, making it the world's most important market for growth in the asset management industry. ${ }^{21}$ In 2015 , the government made its controlling shareholder stakes in SOEs fully tradable and since then it has significantly decreased the size of its controlling shareholder blocks. ${ }^{22}$ In recent years, the caps on foreign institutional investors

supra note 6 (when evaluating the corporate governance of a state-owned enterprise vis-à-vis the state, Milhaupt did not consider the possibilities of a minority institutional investor as a check on the company's corporate governance); Edward Rock, Institutional Investors in Corporate Governance, in THE OXFORD HANDBOOK OF CORPORATE LAW AND GOVERNANCE (Jeffrey N. Gordon \& Wolf-Georg Ringe eds., 2018) (when considering the role of institutional investors with regards to corporate governance around the world, Rock made no mention of China; it has completely escaped the debate).

${ }^{16}$ See infra Part II.

${ }^{17}$ Shangshi Gongsi Guquan Fenzhi Gaige Guanli Banfa (上市公司股权分置改革 管理办法) [Measures for the Administration of the Share-trading Reform of Listed Companies] (promulgated by China Securities Regulatory Commission (CSRC). Sept. 5, 2005), available at http://www.lawinfochina.com/display.aspx?lib=law\&id=4552.

${ }^{18}$ See infra Part II.

${ }^{19}$ A-Shares are the shares of listed companies incorporated in mainland China that trade in RMBs on the two Chinese stock exchanges, the Shanghai Stock Exchange (SSE) and the Shenzhen Stock Exchange (SZSE). An "A-Shares Company" refers to a company listed on the SSE or the SZSE. See infra Part II.

${ }^{20}$ See infra Part II.

${ }^{21}$ World Economic Forum, China Asset Management at an Inflection Point, at 5 (July http://www3.weforum.org/docs/WEF_IR_China_Asset_Management_2020.pdf [hereinafter WEF REPORT].

${ }^{22}$ Wang \& Tan, supra note 10, at 1065. 
have been progressively raised and were largely abolished in $2020 .^{23}$ This now makes any analysis of Chinese corporate governance that does not consider institutional investors incomplete.

Considering these watershed developments, it is surprising that the legal literature lacks a recent description of who China's institutional investors are, how they are regulated, and what impact they have on Chinese corporate governance. ${ }^{24}$ This gap in the literature is especially surprising as the role of institutional investors in corporate governance is a primary focus of several of the world's leading corporate law scholars. ${ }^{25}$ This Article aims to take the first step in addressing this conspicuous gap in the literature.

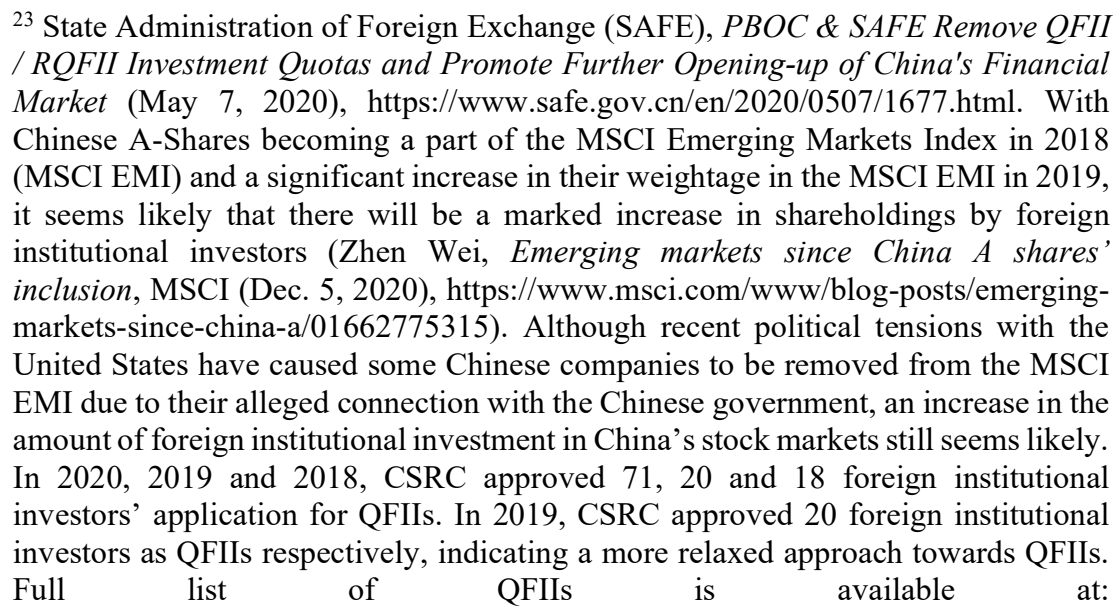
http://www.csrc.gov.cn/pub/zjhpublic/G00306205/201511/t20151106_286098.htm. ${ }^{24}$ The latest significant article on institutional investor activism in China in the legal literature was 15 years ago, see Chao Xi, Institutional Shareholder Activism in China: Law and Practice, 17 INT'L CO. \& COM. L. REV. 251 (2006). Robin Hui Huang has explained why institutional investors did not perform the role of lead plaintiffs in Chinese-style securities class action, see Robin Hui Huang, Private Enforcement of Securities Law in China: A Ten-year Retrospective and Empirical Assessment, 61 AM. J. COMP. L. 757, 787-89 (2013). Recently, Guo Li and Zhao Yijun have published an article relating to institutional investors, which focused more on the US and EU experience, but less on the description of China's situation, see Guo Li \& Zhao Yijun, The Regulation of Proxy Advisors: Experiments and Lessons from the $U S$ and the $E U$ (机构投资者投票顾问的法律规制——美国与欧盟的探索及借 鉴), 1 J. COMPAR. L. (比较法研究) 152 (2019).

${ }^{25}$ See, e.g., Lucian A. Bebchuk et al., The Agency Problems of Institutional Investors, 31 J. ECON. PERSP. 89, 92-93 (2017); John C. Coates, IV, The Future of Corporate Governance Part I: The Problem of Twelve, 2-5 (Harv. Public Law Working Paper No. 19-07, 2019); Jill Fisch, The Uncertain Stewardship Potential of Index Funds, in GLOBAL SHAREHOLDER STEWARDSHIP (Dionysia Katelouzou \& Dan W. Puchniak eds., forthcoming); Ronald J. Gilson \& Jeffery N. Gordon, The Agency Costs of Agency Capitalism: Activist Investors and the Revaluation of Governance Rights, 113 COLUM. L. REV. 863, 874-76 (2013); Rock, supra note 15. 
In Part II, we draw on the most accurate and up-to-date Chinese sources to describe the taxonomy of institutional investors in China. The taxonomy reveals that as the percentage of the A-Shares market owned by institutional investors has grown, there has been a proliferation in the different types of institutional investors in Chinawhat we coin the "atomization" of the market for institutional investors. ${ }^{26}$ An analysis of the regulations that have driven the growth and atomization of institutional investors demonstrates that for decades, the CCP has actively promoted the growth of institutional investors to improve corporate governance and stabilize the stock market. It also reveals that the CCP has strategically controlled the growth and influence of foreign institutional investors, making China the most domestically dominated major market for institutional investors in the world-in which the big three American institutional investors (i.e., Blackrock, State Street and Vanguard) are inconsequential. This has allowed the CCP to rapidly develop a sizable and effective market for institutional investors, while ensuring that it reinforces the China Model of corporate governance in which the CCP maintains ultimate control.

In Part III, we collect and analyze a growing number of empirical studies in the business school literature that provide three valuable insights into the role played by institutional investors in Chinese corporate governance. First, they provide convincing evidence that different types of institutional investors have different impacts on Chinese corporate governance-confirming the value of the taxonomy of institutional investors analyzed in Part II. ${ }^{27}$ Second, several empirical studies find that the impact that institutional investors have on corporate governance is contingent on the extent to which the institutional investor is insulated from the $\mathrm{CCP}$ highlighting the importance of distinguishing between State-Owned Institutional Investors (SOIIs), Private-Owned Institutional Investors (POIIs), and Foreign-Owned Institutional Investors (FOIIs). ${ }^{28}$ Third, several empirical studies find that the impact that institutional investors have on corporate governance is contingent on whether the investee company is a SOE or POE-reinforcing the importance of understanding the role of the CCP in China's market for institutional investors. $^{29}$

However, as explained in detail in Part III, as insightful as these empirical studies are, they suffer from some limitations in their currency, data, and analysis. They also fail to explain how institutional

\footnotetext{
${ }^{26}$ See infra Part II.

${ }^{27}$ See infra Part III.

${ }^{28} I d$.

${ }^{29} \mathrm{Id}$.
} 
investors, who in almost all companies are collectively minority shareholders, produce a statistically significant impact on corporate governance. To overcome some of these blind spots in the empirical studies, we hand-collected and analyzed publicly reported representative cases in which institutional investors, acting as minority shareholders, have been involved in Activist Campaigns in A-Shares Companies. Somewhat surprisingly, our analysis of these cases revealed that SOIIs have undertaken a significant portion of the Activist Campaigns and that POIIs have succeeded in more than half of their Activist Campaigns targeting SOEs. ${ }^{30}$ Over the last decade the number of Activist Campaigns by POIIs, several of which have succeeded in SOEs, are on the rise. ${ }^{31}$ Moreover, based on the searches we have conducted, FOIIs have undertaken only two activist campaigns, none of which were in the last decade. ${ }^{32}$ Finally, Activist Campaigns overall are clearly on the rise, with three times as many Activist Campaigns in the last decade compared to two decades ago. ${ }^{33}$ Taken together, as explained in detail in Part III, this suggests that SOIIs and POIIs are developing into an important corporate governance mechanism to mitigate private benefits of control in China - while the role of FOIIs remains limited. It also suggests that the relationship between the $\mathrm{CCP}$ and institutional investors is important and complex.

In Part IV, we aim to make sense out of this complexity by mapping and analyzing the various government bodies, regulations, and tactics that the CCP has developed to control institutional investors formally and informally in China. Based on empirical, case study, and interview evidence, we explain how the CCP can-and has-used various mechanisms to engage in "policy channeling" 34 in SOIIs and

\footnotetext{
${ }^{30}$ From 1994 to $2021,30.2 \%$ (13 out of 43) of the Activist Campaigns were undertaken by SOIIs, with SOIIs and POIIs collaborating in $11.6 \%$ (5 out of 43 ) of the Activist Campaigns. In the cases in which a POII targeted an SOE, the POII succeeded in 57.1\% (4 out of 7) of the Activist Campaigns. See infra Appendix 2.

${ }^{31}$ From 1994 to 2010, 30\% (3 out of 10) of the Activist Campaigns were undertaken by POIIs, with SOIIs and POIIs collaborating in 20\% (2 out of 10) of the Activist Campaigns; whereas from 2011 to 2021, 60.6\% (20 out of 33) of the Activist Campaigns were undertaken by POIIs, with SOIIs and POIIs collaborating in $9.1 \%$ (3 out of 33) of the Activist Campaigns and an FOII and a POII collaborating in 1 Activist Campaign. See infra Appendix 2.

${ }^{32}$ The two cases undertaken by FOIIs both occurred in 2012. See infra Appendix 2.

${ }^{33}$ From 1994 to 2010, there were 10 Activist Campaigns; whereas from 2011 to 2021, there were 33 Activist Campaigns. See infra Appendix 2.

34 The term "policy channeling" was first coined by Milhaupt and Pargendler in their research on related party transactions in SOEs. Curtis Milhaupt \& Mariana Pargendler, Related Party Transactions in State-Owned Enterprises: Tunnelling, Propping, and Policy Channeling, in The LAW AND FInANCE OF Related PARTY TransaCtions 245, 245-46 (Luca Enriques \& Tobias Troger eds., 2019). See also
} 
POIIs, with foreign institutional investors being largely insulated from policy channeling. Equally important, however, is our evidence that the CCP uses its power to policy channel in a targeted and limited way surrounding significant stock market and political events. On a day-today basis, absent these extraordinary events, institutional investors in China appear to be driven mostly by free market-forces. Empirical, interview, and case study evidence suggests that institutional investors often serve an important corporate governance function by acting as a check on corporate controllers in SOEs and POEs. This fits with other research on Chinese corporate governance that demonstrates that the government has created a system to mitigate private benefits of control-even when it means constraining the power of SOEs-while at the same time ensuring the CCP maintains ultimate control. ${ }^{35}$

In Part V, we conclude by taking a step back and briefly considering what this examination of institutional investors tells us about China's unique form of capitalism and system of corporate governance. The evidence in this Article suggests that the rise of institutional investors in China has been done in a way to reinforce the CCP's ultimate control. However, contrary to what some conceptions of "state capitalism" may suggest, the CCP does not micro-manage institutional investors on a day-to-day basis. Rather, institutional investors normally function according to free-market forces and increasingly perform an important corporate governance role-with the CCP using its policy channeling in a targeted way to stabilize the market in times of crisis, execute important legal and market reforms, and to maintain calm in society during critical political events. This is what we term as the "market within the state" for institutional investors in China. ${ }^{36}$

\section{The Rise OF InSTITUTIONAL INVESTORS IN CHINA - A REMARKABLE, YET OVERLOOKED, HISTORY}

\section{A. Institutional Investors in China Can No Longer Be Ignored}

\footnotetext{
Ronald Gilson \& Curtis Milhaupt, Shifting Influences on Corporate Governance: Capital Market Completeness and Policy Channeling (ECGI Law Working Paper No. 546/2020, Jan. 2021), https://ssrn.com/abstract=3695309. In this Article, we extend the use of the term "policy channeling" to institutional investors in China. In this context, "policy channeling" refers to the CCP's instrumental use of institutional investors for economic policies or social purposes-as opposed to institutional investors focusing on maximizing the value of the funds they own/manage.

${ }^{35}$ Howson, supra note 9, at 52; Wang \& Tan, supra note 10, at 1094.

${ }^{36}$ The term "market in state" was coined by Yongnian Zheng and Yanjie Huang in their book, MARKeT In STATE: The Political ECONOMY OF DOMINATION IN CHINA (Cambridge University Press, 2018).
} 
The meteoric rise of institutional investors in China is difficult to overstate. As is clear in Chart 1 below, in 2003 the percentage of the A-Shares market owned by institutional investors was a miniscule $1.4 \%$. By 2008, the percentage of institutional investor ownership had increased more than eightfold to $11.8 \%$. As of 2018 , institutional investors held $18.7 \%$ of the market capitalization of A-Shares.

\section{Chart 1: A-Shares Investors Based on Market Capitalization (2003 to 2018$)^{37}$}

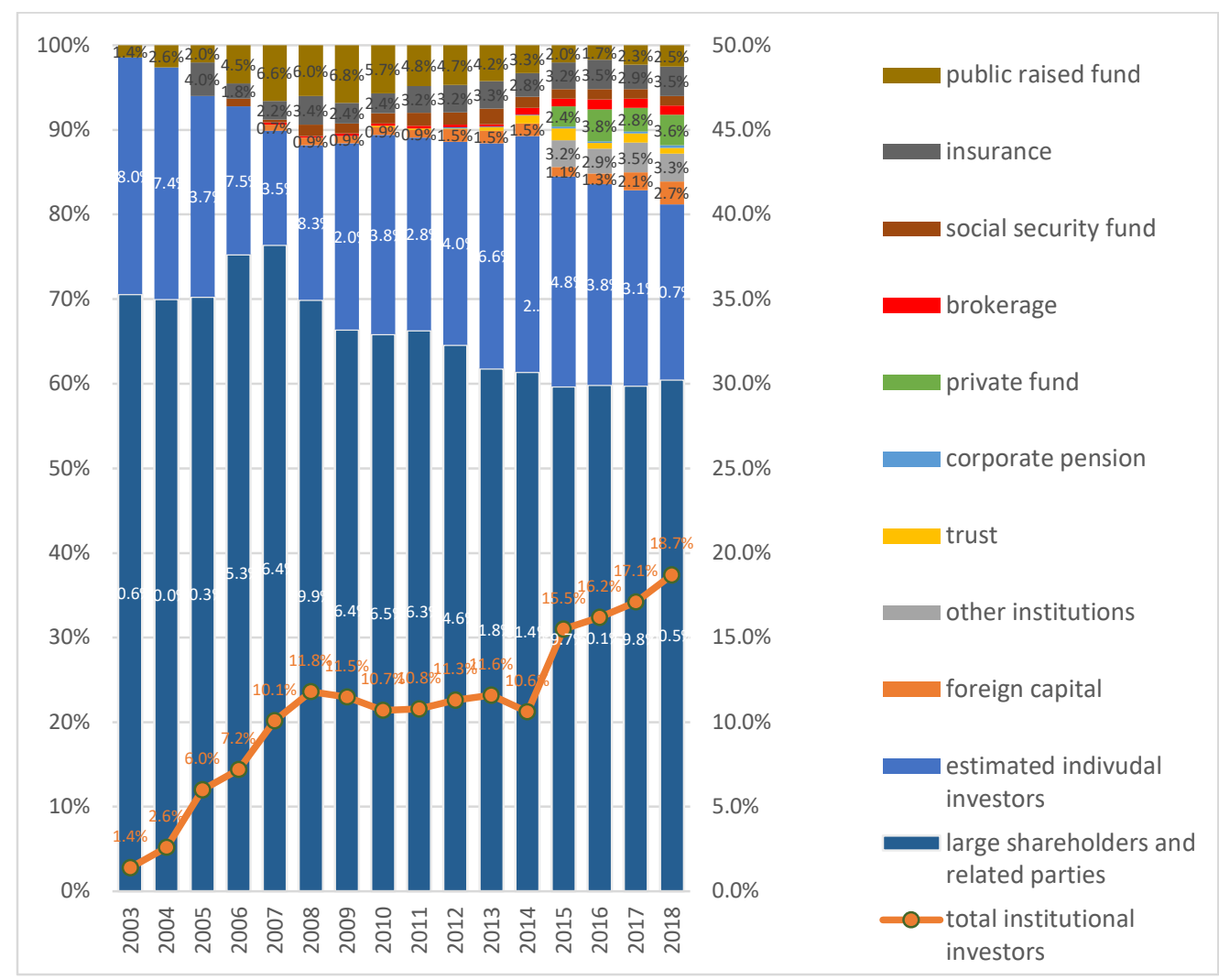

${ }^{37}$ The data is taken from CICC Global Institute (中金公司研究部), CICC: the Proportion of Retail Investor in A-Shares Market Has Declined Significantly (“中金 公司： A 股 “散户化”已经明显下降”) (July 2, 2019), https://m.21jingji.com/article/20190702/herald/b39f0f661609f2353cdfafbb8d88b97 4.html. Other institutions include other professional institutions (其他专业机构) and products (such as asset management plans of futures firms (期货公司资产管理计 划), financial companies (财务公司), and wealth management products of commercial banks (商业银行理财产品)). Total institutional investors refer to investors excluding estimated individual investors, large shareholders and related parties. 
The increase in control that institutional investors have over the free-float in China's A-Shares market has been equally dramatic. ${ }^{38}$ As is evident in Chart 2 below, in 2003 institutional investors controlled merely $4.6 \%$ of the free-float of A-Shares. By 2007, the portion of the free-float controlled by institutional investors had increased more than ninefold to $42.9 \%$ and in 2018 , reached $47.5 \%$ - making institutional investors China's most important minority shareholders. As such, it is now clear that institutional investors are an important part of Chinese corporate governance.

\footnotetext{
38 "Free float market capitalization" is the amount of capital stock (known as free float) that is left after excluding the illiquid shares in the share capital of the listed company and the basically illiquid shares due to strategic holdings or other reasons multiplied by the share price. It can reflect the stock price changes of the actual shares in circulation in the market. The excluded illiquid shares include: (i) long-term shares held by the company's founders, family members, senior managers; (ii) state-owned shareholders; (iii) shares held by strategic investors; (iv) frozen shares; (v) shares held by restricted employees; and, (vi) cross-held shares of listed companies. The restricted shares published in the public notice of the listed company and the shares held by the above six types of shareholders and their persons acting in concert over $5 \%$ are considered as non-freely circulated capital stock. See SSE 180 and SSE 50 Index Compilation Rules (上证 180、上证 50 指数编制细则), promulgated by SSE in June, 2010, http://www.sse.com.cn/market/sseindex/indexlist/indexdetails/indexrules/c/Index Methodology_CN_000010n16.pdf.
} 


\section{Chart 2: A-Shares Institutional Investors as a Percentage of Free-Float Market (2003 to 2018) ${ }^{39}$}

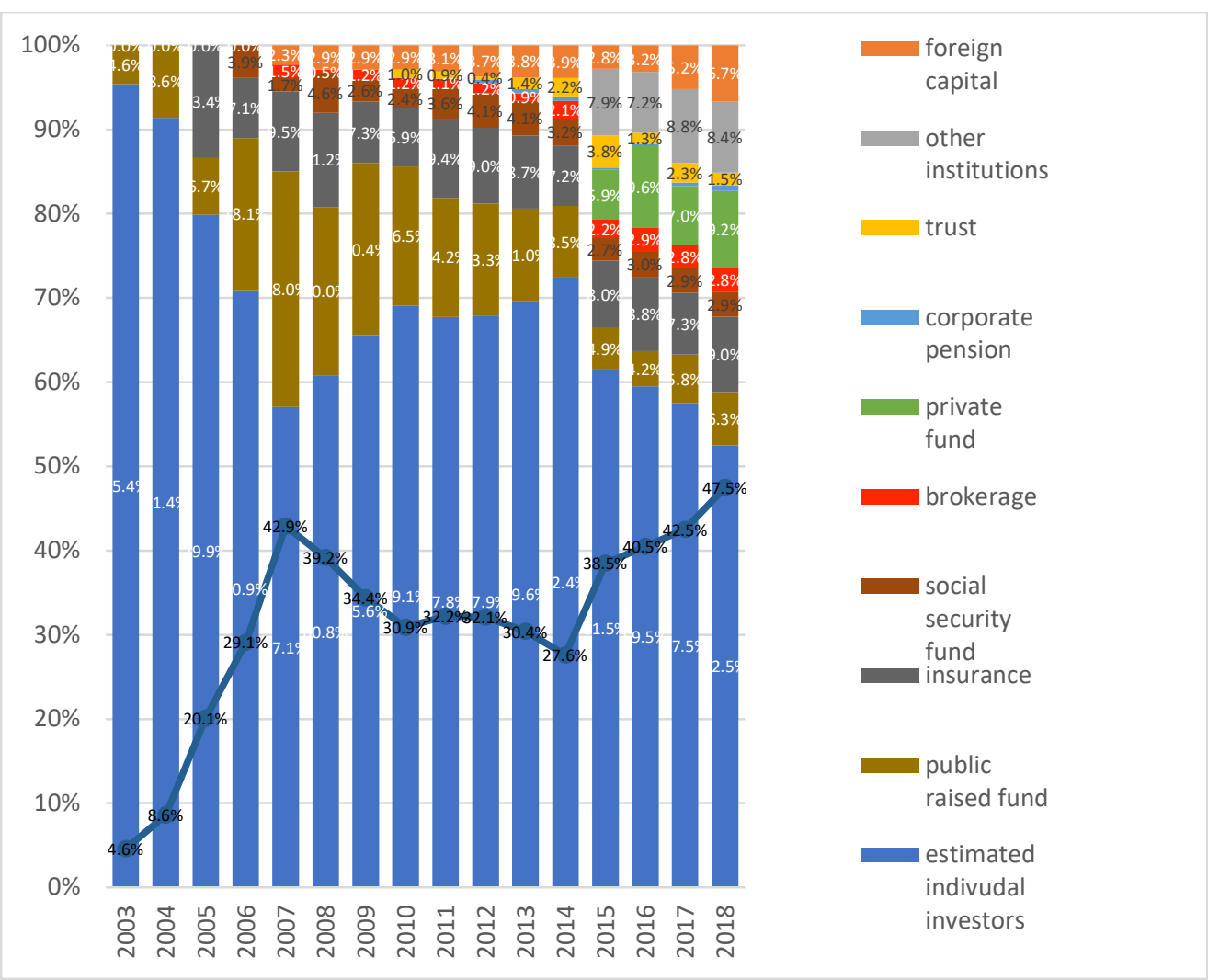

The global institutional investor community has come to recognize the importance of institutional investors in China. Recent reports have identified China's asset management market as the world's most important for growth in the industry and have valued it at US\$16 trillion. ${ }^{40}$ Yet, surprisingly, even though the role of institutional investors in corporate governance has become a core issue among Anglo-America's leading comparative corporate law scholars, the remarkable rise of Chinese institutional investors has been almost entirely overlooked in the legal literature. ${ }^{41}$

\footnotetext{
${ }^{39}$ CICC Global Institute, supra note 37.

${ }^{40}$ WEF Report, supra note 21.

${ }^{41}$ Rock, supra note 15 (This chapter was part of an extensive global corporate law and governance research project, but there was not a single mention of institutional investors in China. This is consistent with the most of the leading literature on the impact of institutional investors on corporate law and governance, which has tended to focus on the US and UK). See generally Bebchuk et al., supra note 25, at 92-93; Coates, supra note 25; Fisch, supra note 25; Gilson \& Gordon, supra note 25.
} 
Before analyzing how institutional investors fit into the China Model of corporate governance, it is essential to recognize that institutional investors in China are not monolithic. As illustrated in the taxonomy of institutional investors in Chart 3 below, there are a variety of institutional investors in China. It is important to understand these varieties as each of them is subject to different regulatory regimes. By mapping the regulatory developments for each variety, a clear picture emerges of how the Chinese government has used its regulatory power to facilitate and shape the growth of different types of institutional investors over the last several decades (See Appendix 1, for a summary of all the relevant regulatory provisions related to institutional investors, listed in chronological order, and categorized based on the type of institutional investor they regulate).

As examined in detail in Part IV, the different varieties of institutional investors have distinct regulatory regimes. As a result, the manner and extent to which each variety is subject to direct and indirect government control also differs among them. However, despite these differences, our detailed analysis below reveals two features that cut across all varieties: (1) over the last several decades the Chinese government has consistently used its regulatory power to facilitate the growth of institutional investors overall; and, (2) the Chinese government has designed a regulatory regime for institutional investors that reinforces the China Model of corporate governance, which aims to improve the efficiency of corporate governance, while ensuring that the CCP maintains ultimate control over the financial system. 


\section{Chart 3: Taxonomy of Institutional Investors in China's A- Shares Market ${ }^{42}$}

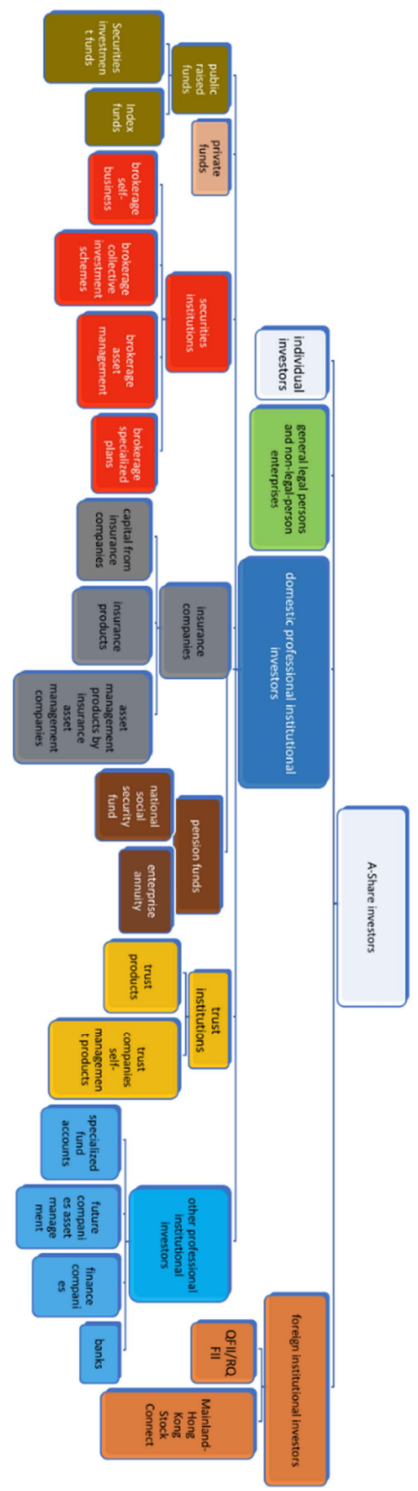

\footnotetext{
${ }^{42}$ The taxonomy is based on Ownership Structure of the A-shares Investors (起底 A 股投资者筹码--A 股投资者结构专题 2020Q2), SINA FINANCE (Sept. 9, 2020), https://finance.sina.com.cn/stock/stockzmt/2020-09-09/doc-iivhuipp3290986.shtml. See also Gupiao Touzizhe Fenlei Biaozhun (股票投资者分类标准) [The Criteria for Classifying Equity Investors] in Zhengquan Qihuoye Tongji Zhibiao Biaozhun Zhiyin (证券期货业统计指标标准指引) [The Guidelines on the Statistical Indicator Standards for the Securities and Futures Industry], promulgated by CSRC on Jan. 1 , 2020, http://www.csrc.gov.cn/pub/zjhpublic/zjh/201912/P020191220532662778070.pdf.
} 


\section{B. Foreign Institutional Investors: A Small, But Growing, Piece of the Taxonomy}

The first important bifurcation in the taxonomy is between domestic institutional investors and foreign institutional investors. Foreign institutional investors refer to investors who enter the AShares market through the qualified foreign institutional investors (QFII) regime, the Renminbi qualified foreign institutional investors (RQFII) regime, and Mainland-Hong Kong Stock Connect (lu gu tong).

China is unique among most major economies with respect to how small of a percentage of its stock market is owned by foreign institutional investors. ${ }^{43}$ As can be seen in Chart 1 above, until 2007 there was no measurable foreign institutional investor ownership registered in the A-Shares market. From 2007 to 2011, the level of foreign institutional ownership in the A-Shares market was paltry, remaining at below $1 \%$. Although the percentage of foreign institutional investor ownership has increased since 2016, it registered at only $2.8 \%$ of the A-Shares market in 2018 .

The small percentage of the A-Shares market owned by foreign institutional investors makes China an outlier as foreign institutional investors have come to play a significant (and, in some countries such as the UK, even dominant) role in most of the world's other major stock markets. ${ }^{44}$ Relatedly, the US "Big Three" institutional investors (BlackRock, Vanguard, and State Street) -which have attracted considerable academic attention and are the largest institutional investors globally-have heretofore owned a miniscule percentage of shares in the Chinese stock market. ${ }^{45}$

The small percentage of foreign institutional ownership in the Chinese stock market is the result of strict regulatory caps that have

\footnotetext{
43 Adriana De La Cruz et al., Owners of the World's Listed Companies, OECD CAPITAL MARKET SERIES (Oct. 17, 2019), https://www.oecd.org/corporate/Ownersof-the-Worlds-Listed-Companies.htm.

${ }^{44}$ WEF Report, supra note 21.

${ }^{45}$ See 杨佼(Yang Jiao), The Evolution of A-shares Investors in the Past Thirty Years: Voice of Institutional Investors Increased; The Percentage of Retail Investors Decreased to 30\% (A 股投资者 30 年变迁：机构话语权提升，散户持股占比降 至 30\%), YICAI (Nov. 30, 2020), https://www.yicai.com/news/100858573.html. Major institutional investors such as Vanguard have relinquished their bid for a fund license, and will instead be relying on their joint venture with Ant Financial. See Shock and Tears: Behind Vanguard's Retreat From China Market, BLOOMBERGQUINT (Apr. 30, 2021), https://www.bloombergquint.com/markets/shock-and-tears-behind-vanguard-sretreat-from-china-s-market.
} 
historically been placed on foreign institutional investors. In 2002, the Chinese government launched the highly restrictive QFII scheme, which for the first time allowed foreign institutional investors to invest in the Chinese securities market. ${ }^{46}$ This required foreign investors to apply to the CSRC for its approval to invest. If approved, the foreign investor would receive a limited quota on the approved amount that could be invested from the State Administration of Foreign Exchange (SAFE).

The approved amount under the SAFE investment quota was subject to a one-year lock-in period during which time the investment funds had to remain in China. ${ }^{47}$ Under no circumstances could the total combined percentage of shares held by all the QFIIs in a single listed company exceed $20 \%$ of its total shares nor could a single foreign investor own more than $10 \%$ of shares in a listed company. ${ }^{48}$ In addition, to qualify for the QFIIs scheme, fund management companies had to have a minimum of US\$10 billion in assets under management in their previous financial year and at least five years of operational experience, while insurance companies were required to have at least 30 years of experience and paid-in capital of at least US\$1 billion. ${ }^{49}$ The restrictions limited QFIIs to major international investment banks who, due to the strict quotas and restrictions, individually and collectively could only own a small percentage of shares in Chinese listed companies.

Since 2002, as set out in detail in Appendix 1, the investment restrictions and lock-in period for QFIIs have progressively been relaxed to facilitate the inflow of more foreign institutional investments. Importantly, as part of this initiative, in 2005 the Ministry of Commerce, the CSRC, the State Administration of Taxation, the State Administration for Industry and Commerce, and the State

\footnotetext{
${ }^{46}$ Hege Jingwai Jigou Touzizhe Jingnei Zhengquan Touzi Guanli Zanxing Banfa(合 格境外机构投资者境内证券投资管理暂行办法) [Interim Measures for the Administration of Domestic Securities Investment by Qualified Foreign Institutional Investors], promulgated by CSRC and PBOC on Nov. 5, 2002.

${ }^{47}$ Wei Huang \& Tao Zhu, Foreign institutional investors and corporate governance in emerging markets: Evidence of a split-share structure reform in China, $32 \mathrm{~J}$. CORP. FIN. 312, at n.10 (2015).

${ }^{48}$ See Guanyu Shishi Hege Jingwai Jigoou Touzizhe Jingnei Zhengquan Touzi Guanli Banfa Youguan Wenti De Tongzhi (关于实施《合格境外机构投资者境内 证券投资管理办法》有关问题的通知) [Notice on Issues Relating to the Implementation of the Measures for the Administration of Domestic Securities Investment by Qualified Foreign Institutional Investors], promulgated by CSRC on Aug. 24, 2006, http://www.csrc.gov.cn/pub/newsite/flb/flfg/bmgf/jj/hgjw/201012/t20101231_1897 93.html.

${ }^{49}$ Huang \& Zhu, supra note 47, at 315.
} 
Administration of Foreign Exchange jointly issued a new measure to allow strategic investments in A-Shares listed companies by foreign investors. The measures took effect in 2006, and as is clear in Chart 1 above, foreign institutional investors began to invest in the A-Shares market in $2007 . .^{50}$

In 2012, the limitations on the total combined percentage of shares held by all the QFIIs, RQFIIs, and Mainland-Hong Kong Stock Connect investors ${ }^{51}$ in a single listed company was increased to $30 \% .{ }^{52}$ In 2018, SAFE issued new provisions ${ }^{53}$ that abolished the lock-in

${ }^{50}$ Waiguo Touzizhe Dui Shangshi Gongsi Zhanlue Touzi Guanli Banfa (外国投资 者对上市公司战略投资管理办法) [Administrative Measures for Foreign Investors' Strategic Investments in Listed Companies], promulgated by the Ministry of Commerce, the CSRC, the State Administration of Taxation, the State Administration for Industry and Commerce, and the SAFE on Dec. 31, 2005.

51 "Mainland-Hong Kong Stock Connect investors" refers to individual investors and institutional investors who trade shares in SSE and SZSE with Hong Kong Securities Clearing Co., Ltd. as the nominee shareholder. See Shanghai Zhengquan Jiaoyisuo Hugangtong Shidian Banfa (上海证券交易所沪港通试点办法) [SSE-Hong Kong Stock Connect Pilot Scheme] (promulgated by Shanghai Stock Exchange, Sept. 26, 2014, effective Sept. 26, 2014, available at http://www.sse.com.cn/aboutus/mediacenter/hotandd/c/c_20150912_3988783.shtm 1; Neidi Yu Xianggang Gupiao Shichang Jiaoyi Hulian Hutong Jizhi Ruogan Guiding (内地与香港股票市场交易互联互通机制若干规定) [Several Provisions on the Inter-connected Mechanism for Trading on Stock Markets in the Mainland and Hong Kong] (promulgated by China Securities Regulatory Commission, Sept. 30, 2016, effective Sept. 30, 2016), available at http://app.westlawchina.com/maf/china/app/document?src=nr\&docguid=i00000000 00000157a366d4a56c57f541\&lang=bi; Neidi Yu Xianggang Gupiao Shichang Jiaoyi Hulian Hutong Jizhi Dengji Cunguan Jiesuan Yewu Shishi Xize (内地与香港 股票市场交易互联互通机制登记、存管、结算业务实施细则) [Detailed Implementing Rules for Registration, Depository, and Clearing Services under the Interconnection Mechanism for Transactions in the Mainland and Hong Kong Stock Markets] (promulgated by China Securities Depository and Clearing Co. Ltd., Sept. 30, 2016, effective Sept. 30, 2016), Art 6, available at http://www.chinaclear.cn/zdjs/editor_file/20160930195326513.pdf.

${ }^{52}$ Guanyu Shishi Hege Jingwai Jigoou Touzizhe Jingnei Zhengquan Touzi Guanli Banfa Youguan Wenti De Tongzhi (关于实施《合格境外机构投资者境内证券投 资管理办法》有关问题的规定) [Provisions on Issues concerning the Implementation of the Administrative Measures for Securities Investment Made in China by Qualified Foreign Institutional Investors] (promulgated by China Securities Regulatory Commission, July 27, 2012, effective, July 27, 2012), Art 9(2), available at http://www.csrc.gov.cn/pub/csrc_en/OpeningUp/RelatedPolices/QFII/201211/t201 21105 216513.html.

${ }^{53}$ Hege Jingwai Jigou Touozizhe Jingnei Zhengquan Touzi Waihui Guanli Guiding (合格境外机构投资者境内证券投资外汇管理规定) [Regulations on Foreign Exchange Administration for Domestic Securities Investments by Qualified Foreign Institutional Investors] (promulgated by State Administration of Foreign Exchange, June 12, 2018, effective June 10, 2018), available at http://www.safe.gov.cn/en/2018/0612/1453.html. 
period and the CSRC announced that it would further relax the qualification requirements on foreign investors. In 2019, SAFE announced its decision to abolish the investment quota system under the QFII scheme and, in 2020, SAFE and People's Bank of China (PBOC) issued a new regulation to simplify the administrative requirements on domestic investments by foreign institutional investors. ${ }^{54}$ These policies should make it more convenient for foreign investors to invest in A-Shares in the future-but the $30 \%$ cap on foreign investor ownership in a single A-Shares company will still limit their ability to influence corporate governance. ${ }^{55}$

Although the average percentage of ownership by foreign institutional investors in the A-Shares market has remained small (below 3\%), it is noteworthy that recently they have collectively acquired significant minority holdings in some high profile listed companies. ${ }^{56}$ For example, as of 30 April 2020, QFII, RQFII, and Shenzhen Connect investors held 1.872 billion shares of Midea group, accounting for $26.74 \%$ of its shares. ${ }^{57}$ With Chinese listed companies'

\footnotetext{
${ }^{54}$ See Guojia Waihui Guanliju Quxiao Hege Jingwai Touzizhe Touzi Erdu Xianzhi Kuoda Jingrong Shichang Duiwai Kaifang (国家外汇管理局：取消合格境外投资 者（QFII/RQFII）投资额度限制 扩大金融市场对外开放) [State Administration of Foreign Exchange (SAFE): Cancellation of investment quota restrictions for qualified foreign investors (QFII/RQFII) and expand the financial market opening] (promulgated by State Administration of Foreign Exchange, Sept. 10, 2019, effective Sept. 10, 2019), available at http://www.safe.gov.cn/safe/2019/0910/14040.html ; Jingwai Jigou Touzizhe Jingnei Zhengquan Qihuo Touzi Zijin Guuanli Guiding (境 外机构投资者境内证券期货投资资金管理规定)[Provisions on the Administration of Domestic Securities and Futures Investment Funds of Foreign Institutional Investors] (promulgated by Foreign Exchange Bureau, People's Bank of China, May 7, 2020, effective May 7, 2020), available at http://www.gov.cn/zhengce/zhengceku/2020-05/07/content_5509577.html.

55 See Guanyu Shishi Hege Jingwai Jigoou Touzizhe Jingnei Zhengquan Touzi Guanli Banfa Youguan Wenti De Tongzhi (关于实施《合格境外机构投资者境内 证券投资管理办法》有关问题的规定) [Provisions on Issues Concerning the Implementation of the Measures for the Administration of Domestic Securities and Futures Investments by Qualified Foreign Institutional Investors and RMB Qualified Foreign Institutional Investors] (promulgated by China Securities Regulatory Commission, Sept. 25, 2020, effective Nov. 1, 2020), Article 7(2), available at http://www.csrc.gov.cn/pub/csrc_en/newsfacts/release/202009/t20200925_383652. html.

${ }^{56}$ China Securities Regulatory Commission: The largest shareholder of over 100 listed companies is a foreign strategic investor (证监会: 超百家上市公司第一大 股东是外资战略投资者)，SoHU.COM (Oct. 12，2020，8.19 PM), https://www.sohu.com/a/424142681_561670; Gao Chang, Accelerating the Inflow of Foreign Capital into A-Shares, 3 Companies are Approaching the Upper Limit of Shareholders (外资加速流入 A 股 3 公司持股逼近上限被预警), XINHUA NEWS (May 27, 9:16 AM), http://www.xinhuanet.com/fortune/202005/27/c_1126037849.html.

${ }^{57} \mathrm{Id}$.
} 
inclusion in the MSCI EMI and the aforementioned regulatory caps recently abolished, it seems possible that foreign institutional investors will acquire significant minority stakes in more high-profile A-Shares companies in the future.

There are two important observations that arise from our examination of the regulatory developments in the foreign component of the taxonomy of institutional investors in China. First, the remarkable rise of institutional investors in China has been driven predominantly by Chinese - not foreign-institutional investors. It appears that the lack of foreign investment has been the direct result of the Chinese government's strict regulatory caps and restrictions. Empirical evidence supports this conclusion as foreign institutional investment has increased in lockstep each time the quotas and restrictions have been eased. ${ }^{58}$ As such, the Chinese government, through its regulatory design, has given itself a strong hand to shape and effectively control the vast majority of the market for institutional investors as they are overwhelmingly domestic - a stark contrast to most other major jurisdictions that have struggled to effectively regulate foreign institutional investors which have composed a sizable portion of their markets. ${ }^{59}$ It has also allowed Chinese institutional investors to develop and capture market share with limited competition from foreign institutional investors.

Second, the small ownership stakes of foreign institutional investors have limited their ability to influence Chinese corporate governance-especially as most listed companies in China are dominated by powerful domestic controlling-block shareholders. As examined in detail in Part III below, there is some empirical evidence suggesting that foreign institutional investors have on occasion "punched above their weight" 60 in their ability to impact corporate governance in listed companies in China, despite their small minority shareholdings. However, as explained in Part IV, even if foreign institutional investors increase their holdings and continue to sporadically punch above their weight, this will merely continue to assist with mitigating the extraction of wealth reducing private benefits of control in A-Shares companies, but not fundamentally change the China Model of corporate governance - in which the CCP has ultimate control over SOIIs and POIIs, who dominate the market for institutional investors in China.

\footnotetext{
${ }^{58}$ Ningyue Liu et al., The investment behavior of Qualified Foreign Institutional Investors in China, 54 J. MulTI. FIN. MGMT. 100614, 5 (2020).

${ }^{59}$ See Brian R. Cheffins, The Stewardship Code's Achilles' Heel, 73(6) MoD. L. REV. 1004 (2010).

${ }^{60}$ Huang \& Zhu, supra note 47 , at $312-326$.
} 


\section{Domestic Institutional Investors: The Core of the Taxonomy}

The roots of domestic institutional investors in China can be traced back to 1991 when the first batch of Securities Investment Funds (SIFs, commonly referred to as mutual funds) -Wuhan Securities Investment Fund and Nanshan Venture Capital Fund-were established. In its first few years, the security investment fund industry was fledgling and remained loosely regulated. This started to change in 1997 when the Securities Commission of the State Council (currently dissolved) issued the "Interim Measures on the Management of Securities Investment Funds" (SIF Interim Measures), which established the first provisional framework for the industry. Within a few years, a handful of asset management companies were established, and several close-ended funds were launched. In addition, 75 closeended funds, which were launched prior to the introduction of the SIF Interim Measures, continued to function. ${ }^{61}$

At the dawn of the new millennium, the Chinese government made it a strategic initiative to develop SIFs as a mechanism to stabilize the market and improve Chinese corporate governance. In 1999, the CSRC began the process of liquidating and amalgamating the 75 close-ended funds launched prior to the introduction of the SIF Interim Measures. In 2000, the President of the CSRC and the ViceChairman of the Standing Committee of the National People's Congress both made the development of SIFs a priority to facilitate the development of institutional investors. ${ }^{62}$ Their views were echoed in a CSRC policy paper published in 2000, which promoted the development of SIFs as a mechanism to stabilize the stock market and monitor the controllers of listed companies. ${ }^{63}$

In 2001, China's first open-ended SIF was launched, and openended funds quickly came to dominate the industry. ${ }^{64}$ In 2002, China

\footnotetext{
${ }^{61}$ In March 1998, Jin Tai Fund and Kai Yuan Fund became the first two regulated funds permitted under these Measures. Between 1998 to 1999, the "Old Ten" SIFs were established, comprising 10 companies including China Southern Asset Management, Guotai Asset Management, China Asset Management.

${ }^{62}$ Open-end mutual fund should be the main institutional investors. See Zhou Xiaochuan Points Out: Make the Fund a Major Institutional Investor as Soon as Possible (周小川指出: 尽早使基金成为主要机构投资者), SHANGHAI SECURITIES DAILY (Oct. 25, 2000, 8.02 AM), http://finance.sina.com.cn/2000-1025/18600.html.

${ }^{63}$ Kaifangshi Zhengquan Touzi Jijin Shidian Bafa (开放式证券投资基金试点办法) [Open-ended Securities Investment Fund Pilot Scheme] (promulgated by China Securities Regulatory Commission, Oct. 8, 2000, effective Oct. 8, 2020), available at $\mathrm{http}: / /$ www.gov.cn/gongbao/content/2001/content_61025.htm.

${ }^{64}$ By the end of 2002, the number of open-ended SIFs had increased to 17 and it went on to gradually replace closed-ended funds.
} 
designated institutional investors as an important feature of its corporate governance system by affirming in its inaugural Corporate Governance Code that "institutional investors shall play a role in the appointment of company directors, the compensation and supervision of management and major decision-making processes." 65 On 28 October 2003, the "PRC Securities Investment Fund Law" was promulgated, marking a major milestone as it was the first national law regulating SIFs. ${ }^{66}$

As illustrated in Chart 1 and Chart 2 above, until 2005, SIFs were essentially the only type of institutional investor in the market. As the stock market strengthened in 2006 and boomed in 2007, the popularity, profitability, and size of SIFs increased significantly - and they came to account for $6.6 \%$ of capitalization and $28 \%$ of the freefloat of the A-Shares market. ${ }^{67}$ Since 2003, hedge funds and index funds have been gradually launched, but open-ended mutual funds continue to dominate the market. ${ }^{68}$ In April 2018, the Guiding Opinions on Regulating the Asset Management Business of Financial

${ }^{65}$ Shangshi Gongsi Zhili Zhunze (上市公司治理准则) [CODE OF CORPORATE GOVERNANCE FOR LISTED COMPANIES IN CHINA] (promulgated by China Securities Regulatory Commission, Jan. 7, 2002, effective Jan. 7, 2002), Art. 11, available at http://www.csrc.gov.cn/tianjin/tjfzyd/tjjflfg/tjbmgz/201210/t20121015_215801.htm . See Appendix 1.

${ }^{66}$ Zhonghua Renmin Gongheguo Zhengquan Toouzi Jijinfa (中华人民共和国证券 投资基金法) [Securities Investment Fund Law of the People's Republic of China] (promulgated by the Standing Comm. Nat'l People's Cong., Oct. 28, 2003, rev'd Dec. 12, 2012, effective June 1, 2013), available at http://www.csrc.gov.cn/pub/csrc_en/laws/rfdm/statelaws/201303/t20130328_22282 0.html.

${ }^{67}$ Before 2005, the subscription of these public offering funds relied on a policy of apportionment, where banks often required employees to subscribe to funds proportional to their top-down allocations. After 2006, the stock market began to strengthen and securities fund investment became a successful way of making money. As a result, investors began to treat these funds differently and more investors began to subscribe to the fund on a pro rata basis. With the continued unilateral rise in the stock market in 2007, the size of the public offering fund industry proliferated, peaking at RMB 3.2 trillion. See Liu Xuefei (刘雪菲), Research on the Development Strategy of China's Public Equity Fund Industry in 2018: Competing for Big Asset Management, Looking for Crisis and Opportunities (2018 年中国公募基金行业发 展战略研究: 逐鹿大资管, 寻基金的危与机), Sohu.COM (July 10, 2018, 4.27 PM), https://www.sohu.com/a/240329974_313170.

${ }^{68}$ The first Chinese index fund was set up in January 2003, see How to Select Index Fund (指数基金如何选?), ECONOMIC DAILY (Nov. 22, 2019，6:04 AM), https://finance.sina.com.cn/roll/2019-11-22/doc-

iihnzahi2509827.shtml? source= $=\mathrm{cj} \& d v=$; The first Chinese hedge fund was launched in September 2010, see First Domestic Hedge Fund was Launched (国内首只对冲 基金产品面世易方达基金拨头筹), Renmin Daily (Sept. 2, 2010, 3.13 AM), https://finance.qq.com/a/20100902/001842.html. 
Institutions ${ }^{69}$ placed the regulation of SIFs under the unified supervision of the PBOC, the China Banking and Insurance Regulatory Commission (CBIRC), and the CSRC. ${ }^{70}$

As of 2019, China had a total of 6084 public offering funds with a total value of RMB 14.66 trillion-representing over a tenfold increase in the number of funds a decade earlier and, in 2020, there were 143 fund management companies in China. ${ }^{71}$ Despite this rapid growth over the past decade in absolute terms, the percentage of market capitalization and free-float of the A-Shares market controlled by SIFs has declined (see above, Chart 1 and Chart 2) and now stands at $2.5 \%$ and $6.3 \%$ respectively. This is due to the entry of other types of institutional investors into the market and the even more explosive growth in the capitalization of the A-Shares market as a whole, which we will now describe.

The second major type of domestic institutional investor to enter the Chinese A-Shares market was insurance companies. ${ }^{72}$ In 1980, China's domestic insurance business resumed and the management of insurance funds progressed substantially after the open-door and economic reform policies. ${ }^{73}$ In 2004, the China

${ }^{69}$ Guanyu Guifan Jinrong Jigou Zichan Guanli Yewu De Zhidao Yijian (关于规范 金融机构资产管理业务的指导意见) [Guiding Opinions of the People's Bank of China, the China Banking and Insurance Regulatory Commission, the China Securities Regulatory Commission, and the State Administration of Foreign Exchange on Regulating the Asset Management Business of Financial Institutions] (promulgated by People's Bank of China, Apr. 27, 2018), available at http://www.pbc.gov.cn/en/3688006/index.html.

${ }^{70}$ See Liu, supra note 67.

${ }^{71}$ Asset Management Association of China, Public Fund Industry Data (公募基金 行业数据公荧金, http:/www.amac.org.cn/researchstatistics/datastatistics/mutualfundindustrydata/.

72 The three types of funds that insurance companies have include: (1) the "funds owned by an insurance company” (保险公司自有资金), which refers to the funds accumulated through insurance premiums paid by the insured or the policyholder as well as the funds provided by its investors during its establishment; (2) "insurance products” (保险产品), which refer to the financial instruments, products and services provided by insurance companies to their customers in the insurance market; and, (3) “insurance asset management products” (保险资管产品) which are financial products that are not for public distribution. The insurance company issuing asset management products may sell them by themselves or entrust the products to other institutions to sell them with a commission. Institutions allowed to sell such products on behalf of the insurance company are financial institutions or institutions recognised by the CBRC, such as banks, insurance companies, securities brokerages, trusts, etc.

${ }^{73}$ Yang Qianwen (杨倩雯), 70 Years of Insurance in China: From a Big Insurance Country to a Strong Insurance Country (中国保险 70 年: 从保险大国走向保险强 国), Yicai (Aug. 15, 2019, 9.01 PM), https://www.yicai.com/news/100297014.html (last visited Nov. 24, 2011). 
Insurance Regulatory Commission (CIRC) gave the greenlight to insurance companies to directly invest in the stock market. ${ }^{74}$ Initially, insurance companies and their asset management subsidiaries could only invest up to $5 \%$ of their total assets into the A-Shares market. ${ }^{75}$ Despite this restriction, as shown in Chart 1 and Chart 2 above, in 2005 , insurance companies quickly came to hold $4 \%$ of the market capitalization and $13.4 \%$ of the free-float of the A-Shares market. In 2009 , the revised insurance law expanded the scope of investments permitted for insurance companies, which allowed them to indirectly invest in the stock market through SIFs. ${ }^{76}$ In 2014, the CIRC raised the limit of the proportion of the assets that insurance companies could invest in equities to $30 \%{ }^{77}$

The CCP has actively encouraged insurance companies to increase their investment in the A-Shares market. In 2018, as shown in Chart 1 and Chart 2 above, $3.5 \%$ of the capitalization and $9.0 \%$ of the free-float of the A-Shares market were owned by insurance companies. In 2019 , the premiums collected by the Chinese insurance industry totaled RMB 4.26 trillion, ranking third in the world in terms of their total size, after the United States and Japan. ${ }^{78}$ As less than $20 \%$ of insurance funds are currently invested in equities - and the cap is

\footnotetext{
${ }^{74} \mathrm{Xu}$ Binglan, Insurance firms get greenlight on stocks, CHINA DAILY (Oct. 25, 2004), http://www.chinadaily.com.cn/english/doc/2004-10/25/content_385567.htm. ${ }^{75}$ Baoxian Jigou Touzizhe Gupiao Touzi Guanli Zanxing Banfa (保险机构投资者 股票投资管理暂行办法) [Interim Measures for the Administration of Stock Investment by Insurance Institutional Investors] (promulgated by CIRC and CSRC on Oct. 24, 2004), available at http://www.csrc.gov.cn/pub/newsite/flb/flfg/bmgz/jj1/201012/t20101231_189868.ht $\mathrm{ml}$.

${ }^{76}$ Baoxianfa Xiugai Qingkuang Jieshao (保险法修改情况介绍) [INFORMATION ON THE REVISION OF INSURANCE LAW] (promulgated by the National People's Congress on Mar. 2, 2009), available at http://www.npc.gov.cn/zgrdw/huiyi/lfzt/bxf/200903/02/content 1480632.htm.

77 Zhongguo Baoxian Jiandu Guanli Weiyuanhui Guanyu Jiaqiang He Gaijin Baoxian Zijin Yunyong Bili Jianguan De Tongzhi (中国保险监督管理委员会关于 加强和改进保险资金运用比例监管的通知) [Notice on Strengthening and Improving the Proportional Regulation of the Utilization of Insurance Funds] (promulgated by the China Insurance Regulatory Commission, Feb. 19, 2014, effective Feb. 19, 2014), Article 2, available at https:/mlaw.wkinfo.com.cn/legislation/detail/MTAwMDQyODM3NTE\%3D.

${ }^{78}$ Original Insurance Premium Income in Various Regions across the Country in December 2020 (2020 年 12 月全国各地区原保险保费收入情况表) (promulgated by the China Banking and Insurance Regulatory Commission, Jan. 28, 2021, effective Jan. 28, 2021), available at https://www.cbirc.gov.cn/cn/view/pages/ItemDetail.html?docId=963083\&itemId=9 $54 \&$ generaltype $=0$.
} 
$30 \%$ - there is scope for future growth in the size of the investment by insurance companies in the A-Shares market. ${ }^{79}$

The third major type of domestic institutional investor to enter the Chinese A-Shares market was pension funds. The public pension fund market is bifurcated between government pension funds - which are called social security funds (SSFs) - and corporate pension funds - which are called enterprise annuities. SSFs exist at the local and national levels, the largest of which is the National Social Security Fund (NSSF).

Established in 2000, the NSSF's operations are governed by the Ministry of Finance (MOF) and the Ministry of Labor and Social Security (MOLSS, currently dissolved); while the CSRC and PBOC supervise the activities of the NSSF's investment managers and are the custodians of its funds. From 2001 to 2016, several laws were promulgated to increase the rate of return of NSSF funds. ${ }^{80}$ One of the major initiatives has been to facilitate the NSSF in investing a portion of its funds in the A-Shares market. Initially, the NSSF invested directly in the A-Shares market. However, since 2003, the NSSF has outsourced a portion of its investments to private fund managers, ${ }^{81}$ resulting in it being both a direct and indirect investor in the A-Shares

\footnotetext{
79 See Insurance Business Operation Table (2020 年保险业经营情况表) (promulgated by the China Banking and Insurance Regulatory Commission, Jan. 22, 2021, effective Jan. 22, 2021), available at https://www.cbirc.gov.cn/cn/view/pages/ItemDetail.html?docId=887993\&itemId=9 $54 \&$ generaltype $=0$.

${ }^{80}$ Since 2001, various regulations were issued to facilitate the development of SSFs, including: Quanguo Shehui Baozhang Jijin Touzi Guanli Zanxing Banfa (全国社会 保障基金投资管理暂行办法) [Interim Provisions on the Administration of Investment by the National Social Security Fund] (promulgated by the Ministry of Finance and the Ministry of Labor and Social Security, Dec. 13, 2001); Quanguo Shehui Baozhang Jijin Touzi Guanli Zanxing Guiding (全国社会保障基金境外投 资管理暂行规定) [Interim Provisions on the Administration of Overseas Investment by the National Social Security Fund] (promulgated by the Ministry of Finance, Ministry of Labor and Social Security and the People's Bank of China, Mar. 14, 2006, effective Mar. 14, 2006); Quanguo Shehui Baozhang Jijin Tiaoli (全国社会保 障基金条例) [Regulation on the National Social Security Fund] (promulgated by the State Council, May 1, 2016, effective May 1, 2016).

${ }^{81}$ National Social Security Fund (NSSF) entered into an agreement with 6 fund management companies in 2003 and entrusted them to make investments in the Ashares market (“2003 年 社保基金正式进入股市), SINA (Apr. 9, 2018), http://finance.sina.com.cn/stock/marketresearch/2018-04-09/docifyteqtq6470236.shtml.
} 
market. ${ }^{82}$ The portion of the NSSF's total funds that can be invested directly and indirectly in A-Shares is currently capped at $40 \%$.

As illustrated in Chart 1 and Chart 2 above, in 2006, SSFs accounted for $0.9 \%$ of capitalization and $3.9 \%$ of the free-float of the A-Shares market. Although the size of the NSSF has grown substantially over the past decade - the total capitalization of the AShares market has increased concomitantly. As a result, over the last decade, SSFs have consistently accounted for approximately $1 \%$ to $2 \%$ of the total capitalization and $2 \%$ to $4 \%$ of the free-float of the AShares market.

In 2011, the revised Measures for the Management of Enterprise Annuity Funds was promulgated, which limited the amount that corporate pension funds could invest in equities to $30 \%$ of their financial net worth. As shown in Chart 1 and Chart 2 above, corporate pension funds started investing in the A-Shares market in 2012. Presently, corporate pension funds remain a small portion of the AShares market, accounting for less than $0.5 \%$ of its capitalization and free float - but they have been increasing gradually in importance since 2007 and their total cumulative value reached approximately RMB 300 billion by the end of $2020 .^{83}$

The fourth major type of domestic institutional investor to enter the Chinese A-Shares market was Chinese securities institutions. Securities institutions (zheng quan ji gou/quan shang) are the Chinese version of international investment banks. They invest their own capital and the capital of their clients in a variety of investments, including the A-Shares market. ${ }^{84}$ In 2007 and 2014, the government

${ }^{82}$ Zhou Jingya, NSSF Indirectly Invested in Index Funds (间接参与”股指期货融资
融 券 ), CBN DAILY NEWS (Mar. 30, 2010), https://finance.qq.com/a/20100330/000302.htm.

${ }^{83}$ Deng Xiongying, Corporate Pension Fund Growth burst (3 万亿年内可破! 年金 规模进入爆发增长期，权益投资占比有望上升), SECURITIES DAILY (Oct. 5, 2020), https://news.stcn.com/sd/202010/t20201005_2407640.html.

${ }^{84}$ As shown in the taxonomy of institutional investors in China's A-shares market in Chart 3 above, there are four types of securities institutions in China: (1) "brokerage proprietary securities" (券商自营), which refers specifically to securities companies investing in their own name, with their own funds or with other funds, buying and selling securities products for themselves; (2) "brokerage collective wealth management firms" (券商集合理财), which is also known as the “collective asset management business", and refers to a financial product issued by a securities company that pools the assets of its clients and is managed by professional investors (brokerage firms); (3) “directed asset management securities firms” (券商定向资管 ), which mainly refers to the activities of securities firms accepting single client entrustment, signing contracts with clients, and managing client entrusted assets 
enacted several policies which provided greater access to, and accelerated trading in, the A-Shares market. These reforms appear to have sparked the establishment of securities institutions as significant institutional investors in 2007 and propelled their growth after 2014. As shown in Chart 1 and Chart 2 above, securities institutions first accounted for an extremely small percentage of the A-Shares market in 2007; but since 2016 have consistently accounted for approximately $1 \%$ of the total capitalization and $3 \%$ of the free-float of the market.

The fifth major type of domestic institutional investor to enter the Chinese A-Shares market was trust companies. Prior to 2012, the CSRC had strict restrictions on the ability of trust companies to hold A-Shares. In August 2012, a notice was issued to officially abolish the restrictions on trust companies investing their funds on the stock exchange. ${ }^{85}$ As of 2018 , trust companies accounted for $0.7 \%$ of the total capitalization and $1.5 \%$ of the free-float of the A-Shares market.

The sixth major type of domestic institutional investor to enter the Chinese A-Shares market was private investment funds. These are private funds, which normally receive their capital from high-networth individuals and are managed by investment professionals who launch such funds. Private investment funds have existed since the early 2000s. However, historically, due to legal restrictions on the establishment of private investment funds, they could only invest in the stock market indirectly by opening accounts in the name of corporations, partnerships, or purchasing products from trust companies. This restriction resulted in private investment funds incurring high operational costs. In 2014, the Securities Investment Fund Law was amended to explicitly recognize private investment funds and permit them to open trading accounts to invest directly in the A-Shares market. ${ }^{86}$ As can be seen in Chart 1 and Chart 2 above,

through clients' accounts according to the manner, conditions, requirements and restrictions agreed in the contracts; and, (4) "dedicated asset management by securities companies” (券商专项计划), which mainly refers to asset securitization financing.

${ }^{85}$ Zhongguo Zhengquan Dengji Jiesuan Youoxian Zeren Goongsi Guanyu Xintuo Chanpin Kaihu Yu Jiesuan Youguan Wenti De Tongzhi (中国证券登记结算有限 责任公司关于信托产品开户与结算有关问题的通知) [Notice of the China Securities Depository and Clearing Corporation Limited on Issues Concerning the Account Opening and Settlement for Trust Products] (promulgated by the China Securities Depository \& Clearing Co., Ltd. (CSDC), Aug. 31, 2004, effective Aug. 31 , 2004), available

at http://awinfochina.com/display.aspx?id=a007308c15320202bdfb\&lib=law ${ }^{86}$ CSDC, Zhou Ming: Private Investment Funds Now Admitted for Account Opening and Trading (Apr. 1, 2014), http://www.chinaclear.cn/english/sdc/201404/017e5994a0f34ba680b4ced5dd8f7a1 8.shtml. 
this change in the law created a significant new category of institutional investor, which by 2018 accounted for 3.6\% of the total capitalization and $9.2 \%$ of the free-float of the A-Shares market.

There are four conclusions that can be drawn from the domestic side of the China institutional investor taxonomy. First, the government has consistently promoted the growth of institutional investors in the A-Shares market. Since the 1990s, the government has had an explicit policy of expanding the size and scope of domestic institutional investors. It has achieved this by making the growth of institutional investors an explicit policy of the CCP and, in turn, by consistently promulgating laws relaxing investment restrictions to encourage an increasingly wide scope of financial institutions and investment managers to invest their capital in the A-Shares market. This has made domestic institutional investors the primary driver of the growth within institutional investors in China and resulted in China having the world's most important growth market for asset management.

Second, as China's market for institutional investors has grown, it has become increasingly atomized. As illuminated above SIFs were the only significant institutional investor in the A-Shares Market before 2005 and until 2010, they accounted for more than 50\% of the market. However, there are at least six major categories of institutional investors today-none of which hold more than $4 \%$ of the total capitalization of the A-Shares market. This atomization of institutional investors requires a more nuanced understanding of what drives each of the categories and cautions against speaking generally about "institutional investors" in China-which may have been more justified in the early 2000s when SIFs dominated the market.

Third, as discussed in more detail in Part IV below, the different varieties of domestic institutional investors have different levels of independence from the government. For example, most trust companies $^{87}$ and securities companies ${ }^{88}$ are SOIIs and, therefore, the

\footnotetext{
${ }^{87}$ See Registered Capital and Shareholder Background of 68 Trust Companies in 2021 (2021 年最新 68 家信托公司注册资本及股东背景), SINA FINANCE (Feb. 22, 2021), available at https://finance.sina.cn/fund/sm/2021-02-22/detailikftpnny9049345.d.html?from=wap.

${ }^{88} 8$ out of the top 10 securities companies are actually controlled by the government, including Huatai Securities Co., Ltd. (the actual controller is SASAC of Jiangsu Province), Guotai Junan Securities Co., Ltd. (the actual controller is SASAC of Shanghai City), China Merchants Securities Co., Ltd. (the actual controller is State Council), Shenwan Hongyuan Group Co., Ltd. (the actual controller is State Council), Haitong Securities Co., Ltd. (the actual controller is SASAC of Shanghai City), China Galaxy Securities Co., Ltd. (the actual controller is State Council),
} 
$\mathrm{CCP}$ can more directly control their engagement and voting policies as institutional investors - which may allow the CCP to utilize them more directly for policy channeling. While some of the largest insurance companies are SOEs, there has been a proliferation of private insurance companies who act as POIIs in China. As such, as explained in Part $\mathrm{IV}$, these POIIs are more independent from the $\mathrm{CCP}$, but the $\mathrm{CCP}$ may still use its indirect control over them for policy channeling. Also, the empirical research and our hand-collected evidence from Activist Campaigns in Part III demonstrate the need to recognize the varieties of institutional investors in China-especially the distinction between SOIIs, POIIs, and FOIIs-as this appears to affect their impact on corporate governance.

Fourth, even if all institutional investors were to speak with one voice (which is clearly not the case), collectively institutional investors will still be the minority shareholders in almost every Chinese listed company. This is significant as it distinguishes China from the UK and US, where institutional shareholders collectively control a majority of shares in most listed companies - this gives them the legal right to collectively "steward" them. ${ }^{89}$ However, in China, similar to in most non-UK-US jurisdictions, the ability of institutional investors to collectively steward listed companies normally does not exist - which makes understanding the role institutional investors can play as minority shareholders, in the context of companies with a dominant controlling block shareholder, critically important. ${ }^{90}$ As our handcollected evidence from Activist Campaigns by institutional investors who are minority shareholders in Part III demonstrates, institutional investors are increasingly engaging in shareholder activism to spur corporate governance change. As expected, these campaigns tend to be in A-Shares companies with more dispersed shareholders.

However, somewhat surprisingly, SOIIs have led the majority of these Activist Campaigns, and, in some cases, have succeeded in these campaigns against SOEs. It is to this that we now turn.

CICC (the actual controller is State Council), and China Securities Co., Ltd. (the actual controller is SASAC of Beijing City). See Ranking of Securities Companies by 2020 Operating Performance Indicators (证券公司 2020 年经营业绩指标排名 情况) (promulgated by the Securities Association of China (SAC), Jun. 18, 2021, effective Jun. 18, 2021), available at https://www.sac.net.cn/hysj/zqgsyjpm/202106/P020210621502887608210.pdf; The information of actual controller is taken from "Qichacha" (an enterprise information enquiry system), https://www.qcc.com/ (last visited July 15, 2021).

${ }^{89}$ Dan W. Puchniak, The False Hope of Stewardship in the Context of Controlling Shareholders: Making Sense Out of the Global Transplant of a Legal Misfit, AM. J. COMP. L. (forthcoming 2022).

${ }^{90} \mathrm{Id}$. 


\section{FILLING THE GAP IN THE LEGAL LITERATURE ON INSTITUTIONAL INVESTORS IN CHINA: EMPIRICAL RESEARCH AND ACTIVIST CAMPAIGNS}

\section{A. Illuminating the Gap in the Legal Literature}

As demonstrated in Part II, there has been a meteoric rise in the size, ownership stake, and free-float of shares that institutional investors have in the A-Shares market. However, as noted above, the rise of institutional investors in China has been almost entirely overlooked in the legal literature. ${ }^{91}$ This is somewhat surprising as the role of institutional investors in corporate governance-particularly in the United States and United Kingdom - has become a major focal point for many of the most prominent corporate law scholars. ${ }^{92}$

We suspect that this gap in the legal literature may have arisen for three reasons. First, comparative corporate law scholars have primarily focused on the Chinese government as China's most powerful controlling shareholder through its ownership of nonfinancial SOEs - which may have caused the rise in the shareholder power of institutional investors to be overlooked. ${ }^{93}$ Second, the atomization of China's institutional investors highlighted in Part II may have made the collective rise of institutional investors in China less conspicuous and makes analyzing their impact on corporate governance more complex. Third, the rise of institutional investors in China is uniquely domestically driven, with the big three American institutional investors - which have been the focus of considerable academic attention-playing an inconsequential role in its development. ${ }^{94}$

However, despite the dearth in legal scholarship, over the past decade, there have been a number of empirical studies in the business school literature that provide interesting insights into the role played by institutional investors in Chinese corporate governance. As these studies use different datasets, cover different time periods, and focus on different issues (as would be expected), there is some variation (and

\footnotetext{
${ }^{91} \mathrm{Xi}$, supra note 24.

${ }^{92}$ Bebchuk et al., supra note 25, at 92-93; Coates, supra note 25, at 2-5; Fisch, supra note 25; Gilson \& Gordon, supra note 25 , at 865, 874-876.

${ }^{93}$ Lin \& Milhaupt, supra note 7; Wang, supra note 13; Howson, supra note 9, at 5152; Milhaupt, supra note 6, at 362; Wang \& Tan, supra note 10, at 1094.

${ }^{94}$ Jan Fichtner \& Eelke M. Heemskerk, The New Permanent Universal Owners: Index Funds, Patient Capital, and the Distinction between Feeble and Forceful Stewardship, 49(4) ECON. \& SoC'Y (2020); Lucian Bebchuk \& Scott Hirst, The Specter of the Giant Three, 99 B.U. L. REV. 721 (2019); Lucian Bebchuk \& Scott Hirst, Index Funds and the Future of Corporate Governance: Theory, Evidence, and Policy, 119 ColuM. L. REV. 2029 (2019).
} 
even incongruency) in their findings. Also, as many of the empirical studies focus on data which extend back over a decade, the focus tends to be on SIFs. This makes sense because, as shown in Part II, SIFs were the only significant institutional investor in the A-Shares market until 2005 and until 2010 they accounted for more than $50 \%$ of the market. ${ }^{95}$

Keeping these limitations in mind, we analyze this interesting body of empirical studies below. In addition, we attempt to address some of the shortcomings in the empirical studies by analyzing our hand-collected summary of the publicly reported representative Activist Campaigns that institutional investors have undertaken in China (see Appendix 2). Ultimately, the empirical studies and Activist Campaigns demonstrate that the taxonomy of institutional investors analyzed in Part II matters, as different types of institutional investors appear to play different roles in Chinese corporate governance. Also, the empirical studies and Activist Campaigns suggest that the influence that the government has over SOIIs - and, in some instances, POIIs - may have a significant effect on their impact on corporate governance. Relatedly, there is some evidence that the impact that institutional investors have on the corporate governance of their investee companies may be contingent on whether the investee company is an SOE or POE. Importantly, and somewhat surprisingly, our analysis also reveals that SOIIs have undertaken a majority of the Activist Campaigns and that SOEs have been the target of a number of successful Activist Campaigns.

Taken together, these results highlight the important impact that the CCP's ability to influence SOIIs, and in some cases POIIs, has on the function they play in Chinese corporate governance-and how the insulation of FOIIs from the CCP's influence matters. The mechanisms and tactics that the CCP uses to wield its influence, and the policy channeling reasons for wielding its influence, are the focus of Part IV. For now, we turn to analyzing the interesting body of empirical studies for a more granular view of the impact of institutional investors in Chinese corporate governance.

\section{B. An Analysis of the Existing Empirical Research}

Keeping in mind the limitations on the empirical studies highlighted above, there are at least three meaningful general observations that can be drawn from this body of empirical research. First, most of the empirical studies find that the impact that institutional investors have on the corporate governance of A-Shares companies is contingent on the type of institutional investor-with

\footnotetext{
${ }^{95}$ See supra Part II.
} 
statistically significant differences in several studies being found between domestic institutional investors and foreign institutional investors, ${ }^{96}$ and between SIFs and other types of institutional investors. ${ }^{97}$ Second, several empirical studies find a statistically significant difference in the impact that certain institutional investors have on corporate governance based on the extent to which the institutional investor is insulated from government pressure-due to their size, independence from direct government ownership, or foreign status. ${ }^{98}$ Third, several empirical studies find that the impact that institutional investors have on the corporate governance of A-Shares companies is contingent on the type of company in which institutional investors own shares-with statistically significant differences in several studies being found between SOEs and POEs. ${ }^{99}$

Collectively, these observations confirm that the taxonomy of institutional investors analyzed in Part II is important as there is significant empirical evidence demonstrating that the impact of institutional investors on corporate governance in China's A-Shares companies differs based on the type of institutional investor. The empirical evidence confirming the importance of the extent to which institutional investors are insulated from government pressure suggests that there is also a need to understand the channels through which the government influences institutional investors and the extent to which different types of institutional investors are influenced by these policy channels - which is the focus of Part IV below. The empirical evidence that the impact of institutional investors on corporate governance differs depending on whether the investee company is a SOE or POE requires further analysis - which is also provided in Part IV below.

\footnotetext{
${ }^{96}$ Yongjia Rebecca Lin \& Xiaoqing Maggie Fu, Does institutional ownership influence firm performance? Evidence from China, 49 INT'L. REV. ECON. FIN. 17 (2017) (results show that foreign and large institutional shareholders have the greatest positive effects on firm performance); Huang \& Zhu, supra note 47 at 324 (results suggest that foreign institutional investors are less prone to political pressure from the controlling state shareholders and are more likely to perform an unbiased monitoring role); Reena Aggarwal, May Hu \& Jingjing Yang, Fraud, Market Reaction, and the Role of Institutional Investors in Chinese Listed Firm, 41 J. PORT. MGMT. 92, 107 (2015) (results show the opposite, that domestic mutual funds are the only type of institutional investor who will play any role in monitoring).

${ }^{97}$ Several articles generally suggest that SIFs, more so than other institutional investors, are the best at corporate governance monitoring as compared to other institutional investors: Michael Firth et al., Institutional stock ownership and firms' cash dividend policies: Evidence from China, 65 J. BANKING \& FIN., 91, 105 (2016); Jing Chi et al., Institutional stock ownership and firm innovation: Evidence from China, 50 J. Multinatl. Fin. Mgmt. 44, 55 (2019); Amon Chizema et. al, Mutual funds, tunneling and firm performance: evidence from China, 55 REV. QUANT. FIN. 355, 382-83 (2020).

${ }^{98} \mathrm{Lin} \& \mathrm{Fu}$, supra note 96 , at 18.

${ }^{99} \mathrm{Id}$.
} 
A review of these empirical studies also suggests some more specific normative implications of the rise of institutional investors on Chinese corporate governance. Several studies suggest that SIFsparticularly domestic SIFs when compared with other types of institutional investors - improve the corporate governance of A-Shares companies. Yuan, Xiao, and Zou (2008), published a pioneering study that found statistically significant empirical evidence that ownership by domestic SIFs had a positive impact on the performance of AShares companies ${ }^{100}$ — which has been repeatedly cited in support of the Chinese government's consistent effort over the past two decades to promote SIFs as a valuable corporate governance mechanism. ${ }^{101} \mathrm{In}$ a later article, Aggarwal, $\mathrm{Hu}$, and Yang (2015), found that domestic SIFs are the only type of institutional investor to play a positive monitoring role in Chinese corporate governance-based on a positive correlation between higher domestic SIF ownership and lower fraud. ${ }^{102}$ They also suggest that foreign institutional investors are ineffective monitors due to their small ownership stakes and other domestic institutional investors (i.e., insurance companies, pension funds, and trusts) are compromised by their business relationships with the investee companies they are supposed to monitor. ${ }^{103}$

In a similar vein, Firth et al. (2016) conclude that SIFs improve corporate governance monitoring based on evidence of a positive correlation between SIF ownership and higher cash dividends - which is absent with respect to other institutional investors such as banks, insurance companies, and securities companies. ${ }^{104} \mathrm{Chi}$, Liao, and Yang (2019) similarly find that SIFs significantly increases firm innovation, but this effect is not found for other types of institutional investors, such as insurance companies, pension funds, or QFIIs. ${ }^{105}$ Chizema et al. (2019) also find that an increase in SIF ownership improves firm performance in A-Shares companies by effectively mitigating the tunneling behavior of controlling shareholders. ${ }^{106}$

Collectively, these empirical studies suggest that SIFsparticularly domestic SIFs in comparison to other types of institutional investors - improve the corporate governance in A-Shares companies.

\footnotetext{
${ }^{100}$ Rongli Yuan et al., Mutual funds' ownership and firm performance: Evidence from China, 32 J. BANKING \& FIN. 1552, at 1563 (2008).

${ }^{101}$ Lin \& Fu, supra note 96, at 18.

${ }^{102}$ Aggarwal et al., supra note 96, at 107.

${ }^{103}$ Id.

${ }^{104}$ Firth et al., supra note 97, at 105 (without examining the distinction between foreign and domestic SIFs).

${ }^{105}$ Chi et al., supra note 97, at 54.

${ }^{106}$ Chizema et al., supra note 97, at 382.
} 
However, for three reasons, this conclusion may not be as definitive as it appears. First, all these studies suffer from the risk of endogeneity as it makes sense that SIFs would invest in companies with better corporate governance, raising the specter of reverse causality. Second, none of these studies provide a detailed explanation of how SIFs, with their minority shareholdings, produce a statistically significant impact on corporate governance. Third, many of these studies are based on at least some pre-2010 data, which preceded the atomization of institutional investors and were collected at a time when SIFs dominated the institutional investors market, raising the possibility that other types of institutional investors may now have a greater impact given their increased shareholdings. However, even considering these complicating factors, this body of empirical evidence suggests that there is reason to believe that domestic SIFs appear to improve Chinese corporate governance by acting as a monitor of corporate controllers.

In this context, it is noteworthy that one of the most cited empirical studies on the impact of institutional investors in the AShares market provides strong empirical evidence that in certain circumstances the government can-and will-also exert political pressure on SIFs to achieve its political and economic objectives. Historically, the A-Shares market was divided into tradable and nontradable shares. In 2005, to remedy the incentive and corporate governance problems created by this unique feature of the A-Shares market, the Chinese government initiated the "split share structure reform" to convert non-tradable shares into tradable shares. ${ }^{107}$ To compensate tradable shareholders for the dilution in their stock values that would result from the reform, the government established a requirement that in each company, an amount of compensation had to be proposed by the non-tradable shareholders to the tradable shareholders, and that the proposal had to be approved by two-thirds of the tradable shareholders for the reform to be finalized. ${ }^{108}$ If the proposal was not approved, a three-month waiting period was required before another proposal could be put forward - which would delay the reform process and, if it occurred in too many companies, would be seen as a black mark on the government officials responsible for the reform. ${ }^{109}$ As an earlier attempt at reforming China's unique split share structure in 2001 had failed, the CSRC was determined for this new

\footnotetext{
${ }^{107}$ Huang \& Zhu, supra note 47, at 313.

${ }^{108} \mathrm{Id}$.

${ }^{109}$ Id.; Michael Firth et al., Friend or Foe? The Role of State and Mutual Fund Ownership in the Split Share Structure Reform in China, 45 J. FIN. \& QUANT. ANAL. 685, 689 (2010).
} 
reform scheme to proceed smoothly, and it set the end of 2006 as the deadline for all A-Shares companies to complete the reform. ${ }^{110}$

Firth, Lin, and Zou (2010) examined the impact of state shareholders and SIFs on the amount of the compensation received by tradable shareholders in the split share reform of A-Shares companies. They found that there was a positive statistically significant relationship between state ownership and the compensation received by tradable shareholders. ${ }^{111}$ Considering the earlier failed attempt to reform the split share structure, they reasoned that the government bureaucrats overseeing the non-tradable shares in SOEs had strong incentives to offer higher compensation to tradable shareholders as this would ensure the reform proceeded as quickly as possible by setting a positive example for other A-Shares companies to follow. ${ }^{112} \mathrm{~A}$ successful reform would also advance the government's goal of listing more SOEs as it would avoid shareholder conflict and create favorable investor sentiment. ${ }^{113}$ For the bureaucrats proposing the compensation packages on behalf of the non-tradable shareholders, completing the reform quickly would provide them with political credit for executing the reform successfully, which would move them up the political hierarchy. ${ }^{114}$ Thus, the empirical evidence that bureaucrats in SOEs offered statistically significant higher compensation to tradable shareholders makes perfect sense-it allowed bureaucrats to capture political benefits of control by executing an efficient reform, while not suffering any direct consequences of providing higher compensation which came from the government. Conversely, in POEs, where private investors owned non-tradable shares, they would directly suffer the cost of providing higher compensation to tradable shareholders and would not receive any political benefits for an efficient reform - which explains why in POEs there was statistically significant lower compensation provided to tradable shareholders.

Interestingly, Firth, Lin, and Zou also found a statistically significant negative relationship between SIF ownership of tradable shares and the amount of compensation provided to tradable shareholders - which is contrary to the evidence from the other empirical studies reviewed above that SIFs improve corporate governance and protect (minority) shareholders' interests. ${ }^{115}$ They also found that "[SIF] ownership weakens the positive link between state

110 Robin Hui Huang, The New Takeover Regulation in China: Evolution and Enhancement, 42 INT'L LAW. 153, 156-157 (2008).

${ }^{111}$ Firth et al., supra 109, at 697.

${ }^{112} \mathrm{Id}$. at 690 .

${ }^{113} I d$. at 689.

${ }^{114} \mathrm{Id}$. at $689-690$.

${ }^{115} \mathrm{Id}$. at 697. 
ownership and compensation, suggesting that [SIFs] help state-owned firms get the reform done more quickly and at a relatively lower cost". ${ }^{116}$

Importantly, Firth, Lin, and Zou identified and explained a unique policy channel that was used in the context of this reform to put pressure on domestic SIFs to work with the government to ensure a quick and noncontentious reform. ${ }^{117}$ Specifically, for the purpose of the split share reform, the CRSC removed the authority from fund managers who normally decide how to vote using shares under their management in accordance with market forces and reallocated the voting rights to the Investment Decision Committee (IDC) of the fund management companies. ${ }^{118}$ As explained in more detail in Part IV, this reallocation of voting rights was critically important as the CSRC has a veto power over the appointment and removal of the members of the IDCs of fund management companies, ${ }^{119}$ who are often former government officials and CCP members. Also, to speed up the reform process "the CSRC put direct pressure on mutual funds to vote in the interest of expediting the reform... [by holding] regular meetings with all fund management firms and [using] these occasions to stress the need for reaching a speedy and noncontentious conclusion to the share structure reform proposals". 120

Firth, Lin, and Zou also found a statistically significant negative relationship between ownership of voting shares by other institutional investors (e.g., insurance companies, securities companies, and investment trusts) and compensation. ${ }^{121}$ They concluded that this empirical finding may be due to the relationship these other institutional investors have with the management of the investee companies - which would provide an incentive for these other institutional investors to support the compensation proposed by the management that was backed by non-tradable shareholders. ${ }^{122}$ Importantly, they also posit that these other institutional investors "are

${ }^{116}$ Id. at 703 .

${ }^{117} \mathrm{Id}$. at $692-693$.

${ }^{118} I d$. at 693. See also, Liu Ying (刘瑛), Difficult for Fund Managers to Participate in Split Share Reform as the Voting Right is Reallocated (股改投票权上收 基金经 理翻云覆雨难), China Business News (第一财经日报) (Aug. 31, 2005, 9:28 AM), http://futures.money.hexun.com/1303024.shtml.

${ }^{119}$ Zhengquan Touzi Jijin Fa (证券投资基金法) [Securities Investment Fund Law] (promulgated by the Standing Comm. Nat'1 People's Cong., effective Oct. 28, 2003 and revised on Dec. 28, 2012) ORD. NO. 23 of the PRESIDENT, available at http://english.www.gov.cn/services/investment/2014/08/23/content_281474982978 075.htm.

${ }^{120}$ Firth et al., supra note 109, at 692.

${ }^{121} I d$. at 697.

${ }^{122} \mathrm{Id}$. 
owned by the state [and] may also be under pressure from the CSRC to agree to the compensation terms"- suggesting that these other institutional investors were also coopted by government pressure to ensure that the split share reform was quick and noncontentious. ${ }^{123}$

In another follow-up study on the split share reform, Huang and Zhu (2015) confirmed the statistically significant positive relationship between state ownership and higher compensation. ${ }^{124}$ They also confirmed that this positive relationship decreased with the level of SIF ownership - suggesting that "the controlling state shareholders may exert political influence on [SIF] managers and offer a lower compensation ratio for companies with [SIF] ownership." ${ }^{125}$ Huang and Zhu then extended on Firth, Lin, and Zou's research by examining the relationship between the amount of compensation and the level of QFII ownership. They found a statistically significant positive relationship, "suggesting that QFIIs are less prone to political pressure." 126 Based on several statistically significant empirical findings, they concluded that "foreign institutional investors are less prone to political pressure than their local peers and are more likely to perform arm's length monitoring." ${ }^{127}$ In Part IV, we identify and explain the specific regulatory architecture which makes it clear why this is the case.

There are five important observations that can be derived from the empirical evidence from the split share reform. First, it demonstrates how the CCP's influence over institutional investors can be used for policy channeling - which reaffirms the importance of understanding how the policy channels for institutional investors work as they can turn the role of institutional investors on its head. Second, it demonstrates how different types of institutional investors are impacted differently by policy channeling (in this case, the difference between domestic and foreign institutional investors) and how understanding the extent to which the CCP can influence different types of institutional investors is critically important. Third, it demonstrates how the $\mathrm{CCP}$ may quickly rearrange the regulatory environment - in this case by reallocating the voting rights from fund managers to the IDC - to enhance its ability to use certain types of institutional investors for policy channeling in particular situations. Fourth, it demonstrates how even when the CCP wants to policy channel free market forces remain important-in this case the CCP could have decided the level of compensation by fiat, but instead it

\footnotetext{
${ }^{123} I d$. at 698 .

${ }^{124}$ Huang \& Zhu, supra note 47, at 314.

${ }^{125} \mathrm{Id}$.

${ }^{126} I d$. at $314,319-320$.

${ }^{127}$ Id. at 314 .
} 
chose to subject the compensation to market forces and then to use policy channeling to shape the outcome. ${ }^{128}$ Fifth, the ability for foreign institutional investors to have a significant impact was unique in this case. As the compensation offered by non-tradable shareholders had to be approved by two-thirds of tradable shareholders this increased the voice of foreign institutional investors which, as highlighted in Part II, normally only own a small minority of shares in A-Shares companies. Also, on average, only $35 \%$ of tradable shareholders chose to exercise their votes in the split share reform proposals-suggesting that a (foreign) tradable shareholder with as little as 3.5\% of the total shares may have been able to veto the proposal, making the split shareholder reform atypical in terms of the ability of small minority foreign institutional investors to have formal veto power. ${ }^{129}$

However, even outside of the context of the split share reform, there is a body of empirical research which suggests that foreign institutional investors may have a positive impact on the corporate governance of A-Shares companies - with the most consistent evidence of this effect in POEs (and sometimes contrary evidence in SOEs). Hai, Min, and Barth (2018), found a statistically significant positive relationship between QFII ownership and various measures of good corporate governance, which suggests QFIIs reduce agency costs. ${ }^{130}$ However, this effect disappeared in SOEs, and they attributed to the negative effects of political pressure in SOEs on the ability of QFIIs to improve corporate governance. ${ }^{131}$ Liu, Bredin, and Cao (2020), found a statistically significant positive relationship between the presence of QFIIs and better operating performance in A-Shares companies, with this positive effect less pronounced in SOEs. ${ }^{132} \mathrm{Li}$ (2017), found a statistically significant negative relationship between QFII holdings and wealth tunneling, but this effect was less pronounced in SOEs. ${ }^{133} \mathrm{Lin}$ and $\mathrm{Fu}$ (2017) found statistically

\footnotetext{
${ }^{128}$ It should be noted that before the split share structure reform in 2005 , the State Council issued a government-imposed reform plan in 2001 to sell the non-tradable shares at the market price to make them tradable. However, this reform was followed by a plunge in the share price. To stabilize the A-shares Market, the CSRC announced the suspension of the reform. In 2005, after the unsuccessful experience of government-imposed reform, the CSRC chose the split share structure reform where the tradable shareholders could receive compensation subject to market forces. See Huang, supra note 110.

${ }^{129}$ Firth et al., supra note 109, at 690.

130 Jiang Hai et al., On Foreign Shareholders and Agency Costs: New Evidence from China, 54 EMERG. MKT. FIN. \& TRADE 2815, 2831 (2018).

${ }^{131} \mathrm{Id}$. at 2821.

${ }^{132}$ Liu et al., supra note 58, at 14.

133 Zhengyu Li, The Impact of Qualified Foreign Institutional Investors on Controlling Shareholder's Tunneling: Evidence of Listed Companies in China, 7 AM. J. Indus. \& Bus. MGMT. 522, 534 (2017).
} 
significant empirical evidence demonstrating that institutional investor ownership positively affects the performance of A-Shares Companies - with pressure-insensitive, foreign, and large institutional shareholders having greater positive effects on firm performance than pressure-sensitive, domestic, and small institutional shareholders. ${ }^{134}$ Liu et al. (2018), found statistically significant strong empirical evidence that QFII and SIF ownership significantly improve corporate transparency and governance. ${ }^{135}$

Taken together, this set of empirical evidence seems to suggest that foreign institutional investors have a positive impact on corporate governance in A-Shares companies-especially in POEs. It also suggests that understanding the role played by the state is critically important for understanding the impact of institutional shareholders in China - as the positive corporate governance impact of foreign institutional investors seems to be negatively affected in SOEs where the state is the controlling shareholder. However, as shown in Part II and acknowledged in several of these studies, ${ }^{136}$ foreign institutional investors collectively, on average, have only accounted for between approximately $1 \%$ to $3 \%$ of A-Shares market capitalization over the past two decades, which makes the consistent empirical evidence of their positive impact on corporate governance somewhat puzzling. Also, similar to our observation regarding the empirical evidence that domestic SIFs have a positive impact on corporate governance, the fact that foreign institutional investors are likely to invest in companies that have better corporate governance, raises the possibility that these studies are confounded by reverse causality.

The opacity of exactly how foreign institutional investors may exercise their minority power to have a statistically significant impact on corporate governance highlights an issue that cuts across all types of institutional investors in the A-Shares market. As explained in Part II, although there has been a meteoric rise in the overall percentage of institutional investors in the A-Shares market from $1.4 \%$ in 2003 to $18.7 \%$ in $2018^{137}$, collectively they still, on average, make up a minority of shareholders in A-Shares companies - and most A-Shares companies have a dominant controlling shareholder. This raises the question of exactly how institutional investors have exercised their power to impact corporate governance in A-Shares companies.

\footnotetext{
${ }^{134}$ Lin \& Fu, supra note 96 , at 54 (i.e., institutional investors lacking a business relationship with the investee company).

${ }^{135}$ Ningyue Liu et al., Institutional ownership and corporate transparency in China, 24 FIN. RES. LETTERS 328, 332 (2018).

${ }^{136}$ Liu et al., supra note 58, at 14; Lin \& Fu, supra note 96, at 17.

137 See supra Part II.
} 
To shed some light on this question, we now consider our individual hand-collected case studies that provide a window into exactly how institutional investors have had an impact on the corporate governance of A-Shares companies.

\section{Activist Campaigns: How Institutional Investors as Minority Shareholders Impact Corporate Governance in China}

To gain a better understanding of how institutional investors may be having an impact on the corporate governance in A-Shares companies, we undertook an extensive search using Chinese and English language sources to attempt to locate all the reported representative instances in which institutional investors have taken steps to intervene in the corporate governance of A-Shares companies (Activist Campaigns). ${ }^{138}$ Based on our detailed review of all of the reported representative Activist Campaigns that we could locate, a summary of which is in Appendix 2 below, they reveal six important insights about how institutional investors in China have had an impact on corporate governance.

First, institutional investors have not used Activist Campaigns to intervene in the corporate governance of A-Shares companies very often. As shown in Appendix 2, from 1994 to 2021, there were only 43 Activist Campaigns, which on average amounts to 1.54 campaigns per year. By comparison, from 2018 to 2020, there were 116 activist campaigns per year in the United States. ${ }^{139}$ This stark difference

${ }^{138}$ To attempt to locate all reported instances in which institutional investors have taken steps to intervene in the corporate governance of A-Shares companies, we took the following steps: for Activist Campaigns that occurred from 1994 to 2015, we extracted the information about Activist Campaigns from a research report prepared by the Shanghai Stock Exchange, which is considered to be the most accurate record of Activist Campaigns for this period: Xinchun Wu, Dali Tuijin Jigou Touzi Zhe Canyu Shangshi Gongsi Zhili (大力推进机构投资者参与上市公司治理) [Vigorously Promoting Institutional Investors' Participation in the Governance of Listed Companies], Shanghai Stock Exchange Capital Market Research INSTITUTE (2015), http://www.sse.com.cn/aboutus/research/research/c/3986593.pdf. In June 2021, for Activist Campaigns that occurred from 2016 to 2021, we searched in Chinese and English on the internet for activist campaigns involving institutional investors. We used several search engines and library databases for our searches which used a variety of key words including: “activist shareholder campaigns" (“激 进股东活动”), “shareholder activism” (“股东激进主义”), “institutional investor activism” (“机构投资者激进主义”), “institutional shareholder activism” (“机构股 东激进主义”)，“institutional shareholder lawsuits” (“机构股东诉讼”), “institutional shareholder veto” (“机构股东否决”), and “institutional shareholder proposals” (“机构股东提议”).

139 Lazard, 2018 Review of Shareholder Activism, at 12 (2018), https:/www.lazard.com/media/450805/lazards-2018-review-of-shareholder- 
between Chinese and American corporate governance is unsurprising considering that most A-Shares companies have a dominant controlling shareholder and institutional investors normally are small minority shareholders - the opposite to the United States where institutional shareholders hold $80 \%$ of shares in listed companies and the vast majority of listed companies lack a dominant controlling shareholder. ${ }^{140}$ The ability of institutional investors to engage in shareholder activism is significantly curtailed when they are a small minority shareholder in a company with a dominant controlling shareholder. ${ }^{141}$ As such, it is unsurprising that our review of the 43 Activist Campaigns revealed that they targeted A-Shares companies which were corporate governance outliers: $76.7 \%$ of companies did not have a dominant controlling shareholder and $62.8 \%$ of institutional investors involved in the campaigns owned more than $5 \%$ of the company's shares. ${ }^{142}$ Although, at the earlier stage of the development of the A-Shares market, most of the listed companies were SOEs, ${ }^{143}$ dispersedly held A-Shares companies without a dominant controlling shareholder are becoming more common. This suggests that there may be more activist campaigns by institutional shareholders in A-Shares companies in the future. This may explain why, as shown in Appendix 2 , there were more than three times as many Activist Campaigns from 2011 to 2021 than there were from 2000 to 2010 - as A-Shares companies have become more dispersedly held over the past decade.

Second, Activist Campaigns by FOIIs are extremely rare. Based on Appendix 2, only 2 out of the 43 Activist Campaigns involved FOIIs and in 1 out of the 2 Activist Campaigns involving FOIIs, the FOII joined with a POII to undertake the campaign. Based on the search we conducted to create Appendix 2, we could not find even a single Activist Campaign involving an FOII after 2012. This is unsurprising considering that, as highlighted in Part II, foreign institutional investors did not hold any meaningful percentage of AShares companies until 2007 and since then they have held only between $1 \%$ to $3 \%$ of the shareholder capitalization of A-Shares

activism.pdf; Lazard, 2019 Review of Shareholder Activism, at 8 (2019), https:/www.lazard.com/media/451141/lazards-2019-review-of-shareholderactivism-vf.pdf; Lazard, 2020 Review of Shareholder Activism, at 6 (2020), https://www.lazard.com/perspective/lazards-annual-review-of-shareholderactivism-2020/.

${ }^{140}$ De La Cruz et al., supra note 43, at 12; Puchniak, supra note 89.

${ }^{141} \mathrm{Yu}-\mathrm{Hsin}$ Lin, When Activists Meet Controlling Shareholders in the Shadow of the Law: A Case Study of Hong Kong, 14 ASIAN J. COMP. L. 1, at 7-8 (2019).

${ }^{142}$ The "dominant controlling shareholder" here refers to shareholders who control the investee's shares of over $50 \%$. The data is taken from disclosures of investee companies. See http://eid.csrc.gov.cn/.

143 Robin Hui Huang, Shareholder Derivative Litigation in China: Empirical Findings and Comparative Analysis, 27 BANKING \& FIN. L. REV. 619, 649 (2012). 
companies. In addition, although the regulations limiting foreign institutional investors have been gradually relaxed, there is still a $30 \%$ cap on the percentage of shares that foreign institutional investors can own in an A-Shares company-which prevents foreign institutional investors from being able to execute, or even to threaten to execute, a change of control in A-Shares companies. ${ }^{144}$ It is interesting that out of the two Activist Campaigns involving foreign institutional investors, one targeted an SOE and the other targeted a POE, and both were successful. In the case targeting an SOE, the foreign institutional investors partnered with private domestic institutional investors to elect their directorial candidate over another candidate who was supported by a government shareholder which was the actual controller of the SOE. As explained in more detail in Part IV, this illustrates how foreign institutional investors in some circumstances may be able to have a positive impact on corporate governance as they are more insulated from the mechanisms that the CCP uses to carry out policy channeling in SOIIs and POIIs.

Third, 13 out of the 43 Activist Campaigns listed in Appendix 2 were undertaken by SOIIs, while 23 were undertaken by POIIs, with POIIs and SOIIs collaborating in 5 Activist Campaigns and a POII and an FOII collaborating in 1 Activist Campaign. ${ }^{145}$ It is noteworthy that prior to 2010, half of the Activist Campaigns were undertaken by SOIIs, which are owned by the government and ultimately controlled by the CCP directly or indirectly; whereas since 2010, over half of the Activist Campaigns were undertaken by POIIs. ${ }^{146}$ This suggests an increasing reliance on the private market for institutional investors, in which the CCP only exercises indirect control. As discussed in Part IV, to varying extents, the $\mathrm{CCP}$ through a matrix of policy channels may also control institutional investors which it does not directly own.

Taken together, this challenges the idea that the rise of institutional investors in China may threaten the CCP's ultimate control. However, as we explain in Part IV, merely because the CCP directly or indirectly controls SOEs does not mean that free-market forces are irrelevant. On the contrary, in normal times free-market forces govern the behavior of SOIIs and POIIs, like institutional

\footnotetext{
${ }^{144}$ See supra Part II.

${ }^{145}$ There was 1 Activist Campaign that was undertaken by an FOII. See below, Appendix 2.

${ }^{146}$ From 1994 to 2010, 50\% (5 out of 10) of the Activist Campaigns were undertaken by SOIIs, with SOIIs and POIIs collaborating in 20\% (2 out of 10) of the Activist Campaigns; whereas from 2011 to 2021, 60.6\% (20 out of 33) of the Activist Campaigns were undertaken by POIIs, with SOIIs and POIIs collaborating in $9.1 \%$ (3 out of 33) of the Activist Campaigns and an FOII and a POII collaborating in 1 Activist Campaign. See below, Appendix 2.
} 
investors in other financial markets. However, in extraordinary times (e.g., when there is market instability, or the government wants to undertake a major reform) both SOIIs directly and POIIs indirectly may serve as agents to execute government policy. This reliance on market forces in regular times and use of policy channeling for extraordinary purposes is a phenomenon which we explain as the institutional shareholder "market within the state" in the Conclusion.

Fourth, SOEs were the target in 11 out of 43 Activist Campaigns, and there were 7 cases in which a POII targeted an SOE. It is noteworthy that in 4 of these cases the POII succeeded in its campaign. This illustrates how the government has allowed POIIs to serve as a check on SOEs - which further highlights the complexity and sophistication of China's market within the state. As explained in Part IV, although the government has promoted the emergence of POIIs to serve as a useful check on SOEs, it has also developed policy channels that ensure that the CCP maintains ultimate (indirect) control over POIIs. In addition, POEs were the target in 32 out of 43 Activist Campaigns, with 14 of them involving SOIIs, which demonstrates that this may be another policy channel in which the state can influence or police POEs. It is interesting that only 6 of these campaigns succeeded-again illustrating how SOIIs are bound by the laws and market-forces. Merely because the state is the direct owner of SOIIs does not axiomatically result in a successful Activist Campaign.

Fifth, the evolution of the types of institutional investors that have executed Activist Campaigns confirms our observation in Part II that the market for institutional investors in A-Shares companies has become increasingly atomized. As illuminated in Part II, prior to 2010, SIFs dominated the market. As such, it is unsurprising that, prior to 2011, 8 out of 10 Activist Campaigns were executed by SIFs. However, from 2011 to 2021, 20 out of 33 Activist Campaigns were undertaken by other types of institutional investors such as trust companies, securities companies, insurance companies, and other professional institutions - illustrating how other types of institutional investors have started to participate in the corporate governance of investee companies. This reinforces the importance of the taxonomy of institutional investors described in Part II and highlights why understanding the different types of regulatory regimes impacting different types of institutional investors is important-which is the focus of Part IV.

Sixth, 58.1\% (25 out of 43) Activist Campaigns listed in Appendix 2 were successful, with successful campaigns normally resulting in institutional investors having an impact on corporate governance by preventing the company from engaging in a transaction 
that would harm minority shareholders or providing minority shareholders with a voice on the board. To succeed, small minority institutional investors have had to convince other investors to support their proposals - reinforcing the observation that such campaigns normally only have a chance to succeed in dispersed companies without a dominant controlling shareholder. The only successful hostile takeover bid by an institutional investor was executed in 2017 by Zhemin Tianhong Investment Partnership (L.P.) in its successful \$2.7 billion hostile takeover bid for Zhenxing Biopharmaceutical and Chemical Co., Ltd. ${ }^{147}$ Arguably the key to Zhemin Tianhong Investment Partnership (L.P.)'s success was that Zhenxing Biopharmaceutical was an outlier among A-Shares companies in terms of having an extremely dispersed shareholding structure-illustrating how dispersed shareholding is a key factor in the success of Activist Campaigns in A-Shares companies.

Finally, we would be remiss to not acknowledge what these case studies cannot tell us. Institutional investors often meet and communicate with investee companies informally-which may have an impact on corporate governance. Although most of this communication is normally unobservable, Cheng et al. examined the impact of "site visits" (i.e., when investors visit corporate headquarters or manufacturing facilities to meet with managers in A-Shares companies). ${ }^{148}$ These "site visits" are required to be disclosed in the annual reports of A-Shares companies. They found a significant positive market reaction to corporate site visits and that the market reaction was stronger for visits conducted by SIF managers. ${ }^{149}$ This suggests that some of the empirical evidence described above, which finds that SIFs have a positive impact on corporate governance, may result from informal activities and may not be reflected in Activist Campaigns. We are unaware of any similar research that has focused on foreign institutional investors, but this also raises the possibility that the empirical evidence which suggests that they have a positive impact on the corporate governance of A-Shares companies may be related to their informal activities. More research will have to be done to confirm whether this is the case.

\footnotetext{
${ }^{147}$ Zhenxing Biopharmaceutical and Chemical Co., Ltd. has changed its name to Pacific Shuanglin Bio-pharmacy Co., Ltd., See, Fu Jianqing (付健青), Decoding the First Successful Market-Oriented Hostile Acquisition of A-Shares (解码 A 股首例 成 功 市 场 化 敌 意 收 购 案 ), JNJ (June 29, 2018), https://m.jrj.com.cn/madapter/stock/2018/06/29033024743240.shtml.

${ }_{148}$ Qiang Cheng et al., Do Corporate Site Visits Impact Stock Prices? 36 CONTEMP. ACCT. RES. 359, 364 (2019).

${ }^{149}$ Id. at 381 .
} 
In sum, the relative infrequency of Activist Campaigns illustrates how A-Shares companies are still dominated by controlling shareholders - with institutional shareholders remaining a small minority. However, the rise in the number of Activist Campaigns over the last decade appears to confirm the rising shareholder power of institutional investors highlighted in Part II. The increasing variety in the types of institutional investors executing Activist Campaigns also confirms the atomization of institutional investors and the value of the taxonomy of institutional investors in Part II. Perhaps, most interesting, is the extent to which SOIIs have executed campaigns against SOEs and POIIs have succeeded in campaigns against SOEs. This illustrates the complexity and sophistication of China's unique system of corporate governance, in which the CCP maintains ultimate control, while promoting checks and balances within the government and a "free market within the state". It is to this that we now turn.

\section{The DUAL Roles of INSTITUTIONAL INVESTORS IN CHINA: CORPORATE GOVERNANCE AND POLICY CHANNELING}

\section{A. Illuminating the CCPs Targeted Use of Policy Channeling in an Otherwise Free-Market}

The empirical research and Activist Campaigns in Part III suggest that there is a complex relationship between the CCP and the role that institutional investors play in Chinese corporate governance. This Part aims to make sense out of this complexity by mapping the formal and informal mechanisms that the CCP utilizes to engage in policy channeling. We demonstrate that the CCP can-and has-used various mechanisms to engage in policy channeling in SOIIs and POIIs. Interestingly, for SOIIs and POIIs there are two distinct pathscomposed of various government bodies, regulations, and tactics - for engaging in policy channeling; with FOIIs being largely insulated from both paths.

Equally as important is our evidence that the CCP uses its power to policy channel in a targeted and limited way surrounding significant stock market and political events. On a day-to-day basis, absent these extraordinary events, institutional investors in China appear to be driven by free market-forces. Empirical, interview, and case study evidence suggests that institutional investors often serve an important corporate governance function by acting as a check on corporate controllers in SOEs and POEs. This fits with other research on Chinese corporate governance that demonstrates that the government has created a system to mitigate private benefits of 
control - even when it means constraining the power of SOEs - while at the same time ensuring the CCP maintains ultimate control. ${ }^{150}$

Ultimately, it appears that institutional investors play an important function within the unique China Model of corporate governance. The CCP does not micro-manage institutional investors in a way that some conceptions of "state capitalism" may suggest. ${ }^{151}$ Rather, institutional investors normally function according to freemarket forces and perform an important corporate governance rolewith the CCP using its various mechanisms for policy channeling to execute important policies, which may benefit the market and society, while also possibly blunting the effectiveness of efficient corporate governance. This system is what we explain in the Conclusion as "the market within the state" for institutional investors in China.

\section{B. Illuminating, Classifying, and Mapping the CCP's Mechanisms for Policy Channeling}

The split share reform research provides convincing empirical evidence that the CCP can-and has - used its regulatory power to transform domestic institutional investors into a mechanism for policy channeling. ${ }^{152}$ The CCP's use of institutional investors to achieve its political goals comports with the more recent creation of a "National Team" of government-controlled SOIIs which were tapped to stabilize the A-Shares market after its collapse in 2015. ${ }^{153}$ Although, as

\footnotetext{
${ }^{150}$ Howson, supra note 9, at 52; Wang \& Tan, supra note 10, at 1094.

151 Telephone interview, 30 May 2021, Investment Manager CICC (Shenzhen); Telephone interview, May 30, 2021, Legal Counsel, DBS Securities (China); Telephone interview, May 30, 2021, Senior Manager, CMS (Shanghai); Telephone interview, May 30, 2021, Legal Counsel, DBS Securities (China); Telephone interview, May 30, 2021, Partner, Global Law Office (Beijing); Telephone interview, May 31, 2021, Legal Officer, SAFE; Andrew Szamosszegi \& Cole Kyle, An analysis of state-owned enterprises and state capitalism in China, US-CHINA ECONOMIC AND SECURITY REVIEW COMMISSION, at 52 (Oct. 26, 2011).

152 Firth et al., supra note 109, at 697; Huang \& Zhu, supra note 47, at 314; See supra Part III.

153 Moxy Ying, When Stocks Crash, China Turns to Its 'National Team', WASHINGTON POST (Mar. 9, 2021), https://www.washingtonpost.com/business/when-stocks-crash-china-turns-to-itsnational-team/2021/03/09/d13c540a-80df-11eb-be22-32d331d87530_story.html; Hudson Lockett \& Sun Yu, How the Invisible hand of the state works in Chinese stocks, FinANCIAL TIMES (Feb. 4, 2020), https://www.ft.com/content/0d41cb6e4717-11ea-aeb3-955839e06441; Evelyn Cheng, Goldman: Government-directed traders bought up billions in Chinese stocks last quarter, CNBC (Sept. 11, 2018), https://www.cnbc.com/2018/09/11/goldman-government-directed-traders-boughtnearly-17-billion-in-local-stocks-last-quarter.html; Shen Hong \& Stella Yifan Xie, That Calm Chinese Stock Market? It's Engineered by the State, WALL STREET JOURNAL (May 31, 2018), https://www.wsj.com/articles/that-calm-chinese-stockmarket-its-engineered-by-the-government-1527775089?mod=e2tw.
} 
explained in Part II, the CCP has a long history of using its regulatory power to promote institutional investors as a market stabilizing mechanism, the enormous scale of investment and strategic coordination of a select group of SOIIs in 2015 crystallized the idea of the National Team as an important feature of the A-Shares marketwhich investors now count on to intervene in times of market volatility. ${ }^{154}$

There is also empirical and anecdotal evidence that beyond being a mechanism to facilitate regulatory reforms and stabilize the AShares market, the CCP uses its ownership and control over SOIIs to achieve more overt political objectives. There is evidence that prior to major CCP political events and meetings, the government uses its control over SOIIs to ensure a general level of social stability by keeping the markets calm. ${ }^{155}$ The extent to which market stability is crucial for social stability in China is evident from the fact that, with over 100 million Chinese citizens invested in the A-Shares market, shareholders form an even larger constituency than CCP members. ${ }^{156}$

There is also empirical and anecdotal evidence that the CCP uses its formal and informal power to pressure POIIs - a tactic that has become known as "window guidance"-to reinforce its policy channeling through institutional investors. ${ }^{157}$ In addition to the

\footnotetext{
${ }^{154}$ Id.; Narayanan Somasundaram, Chinese government-back funds snap up stocks to halt plunge, NIKKEI ASIAN REV. (Mar. 9, 2021).

${ }^{155}$ Shen \& Xie, supra note 153.

${ }^{156}$ Charlotte Yang, Caixin Explains: How a Stock Market Crash Created China's 'National Team', CAIXIN (Oct. 19, 2018), https://www.caixinglobal.com/2018-1019/caixin-explains-how-a-stock-market-crash-created-chinas-national-team101337087.html.

157 Telephone interview, May 30, 2021, Partner, Global Law Office (Beijing); Telephone interview, May 30, 2021, Investment manager, CMS (Shanghai); Telephone interview, May 30, 2021, Legal Counsel, DBS Securities (China); Telephone interview, May 30, 2021, Investment manager, CICC (Shenzhen). See also Lockett \& Yu, supra note 153; Cheng Pangyue, Drivers of Institutional Investors' Shareholder Behaviour in China's Listed Companies: A Socio-legal Research of Incentives and Challenges in the New Era, at 25 (on file with authors); See Zhengquan Jijin Jingying Jigou Dongshi, Jianshi, Gaoji Guanli Renyuan Ji Jiuye Renyuan Jiandu Guanli Banfa (Zhengqiu Yijiangao) (证券基金经营机构董事、监 事、高级管理人员及从业人员监督管理办法(征求意见稿)) [Supervision and Administration Measures for Directors, Supervisors, Senior Management and Practitioners Of Securities and Fund Management Organizations (Consultation Paper)] (promulgated by the CSRC on Nov. 20, 2020), Section 3(1) (the appointment of directors, supervisors, senior management and branch heads by securities and fund operators should be filed with the relevant dispatching agencies of CSRC in accordance with the law). Tomoyuki Fukumoto et al., Effectiveness of Window Guidance and Financial Environment - In Light of Japan's Experience of Financial Liberalization and a Bubble Economy, BANK OF JAPAN REV. (Aug. 2010), https:/www.boj.or.jp/en/research/wps_rev/rev_2010/data/rev10e04.pdf.
} 
empirical evidence demonstrating the control over POIIs to facilitate the split share reform, anecdotal evidence suggests that window guidance is used to alter the behavior of POIIs to bolster the CCPs ability to utilize domestic institutional investors to achieve social stability surrounding major political events. ${ }^{158}$

Perhaps unsurprisingly, the empirical evidence in Part III suggests that the CCPs ability to use FOIIs as a conduit for policy channeling is considerably more limited, if not non-existent. This is supported by the empirical evidence regarding the split share reform which suggests that QFIIs acted in the interest of their beneficiaries and their investee companies' tradable shareholders in negotiating the compensation in the reform - as opposed to jettisoning their interests to make the CCP's market reform a success. ${ }^{159}$ There appears to be no evidence that QFIIs have participated in any market stabilization efforts, including the campaign carried out by the National Team following the 2015 market collapse. The independence of QFIIs from the CCP may also help explain why several empirical studies examined in Part III found that QFIIs played a positive monitoring role in AShares companies, despite their modest shareholdings-which, as explained in Part II, have historically been limited by strict regulatory caps that have only recently been relaxed.

Taking a step back, based on the ability of the CCP to utilize institutional investors for the purpose of policy channeling, institutional investors in China can be classified into three broad categories, as depicted in Diagram 1 below. The first category, StateControlled Institutional Investors, is composed of China's SOIIs. The CCP exercises two-tiers of control over SOIIs through both its shareholding network and the appointment of the "First in Command" (yi ba shou) of SOIIs. ${ }^{160}$

First, as the controlling shareholder or actual controller who holds over $50 \%$ of the shares of SOIIs directly or indirectly, the government agencies are able to exercise legal control over SOIIs. ${ }^{161}$ As illustrated in Diagram 1 below, the institutional architecture that has progressively been developed during the SOE reform process has created a complex network of different government agencies (e.g., the State Council, State-owned Assets Supervision and Administration

\footnotetext{
${ }^{158}$ Shen \& Xie, supra note 153.

${ }^{159}$ Huang \& Zhu, supra note 47, at 319.

${ }^{160}$ The chairman of the board, general manager, and party committee secretary are often referred to collectively using the political term the "First in Command" (yi ba shou) of the SOIIs.

${ }^{161}$ The data is taken from "Qichacha" (an enterprise information enquiry system): https://www.qcc.com/> last accessed on Jun. 13, 2021.
} 
Commission of the State Council (SASAC), and the Ministry of Finance and State Administration of Foreign Exchange (SAFE)) holding shares in SOIIs on behalf of the state. ${ }^{162}$ However, it should be noted that more recently, the government policy has been to consolidate the state-owned shares of SOIIs into MOF in order to simplify the shareholding network between government agencies and SOIIs and to strengthen the government's control over state-owned shares. ${ }^{163}$

As the major shareholder of SOIIs, the MOF is able to exercise its shareholder rights under the PRC Company Law (e.g., participating in appointment and dismissal of senior managers ${ }^{164}$, revision of the articles of association, and other decision-making processes) ${ }^{165}$ to control the corporate governance of SOIIs. Notably, this does not mean that MOF exercises any external regulatory power over these SOIIswhich is critically important as all the domestic institutional investors including SOIIs and POIIs are effectively regulated by the three financial regulatory agencies (i.e., PBOC, CBIRC and CSRC, the three agencies are also known as 'one bank and two commissions', yi hang

${ }^{162}$ See Qiye Guoyou Zichan Fa (中华人民共和国企业国有资产法) [Law of the State-Owned Assets of Enterprises] (promulgated by the Standing Committee of the National People's Congress on Oct. 28, 2008) Article 4 and 11. The State Council and the local people's governments perform respectively the investor's functions for state-invested enterprises and enjoy the investor's rights and interests on behalf of the state. The central SASAC, local SASAC or other government agencies can perform the investor's functions and enjoy the investor's rights and interests of the state on the authorization of the State Council and the local people's governments. For example, as depicted in Diagram 1 below, the State Council directly controls CITIC Group and China Everbright Group; SASAC indirectly controls Zhonghai Trust Co., Ltd., China Huadian Finance Co., Ltd. and China State Shipbuilding Finance Co., Ltd.; additionally, the State Council indirectly controls SOIIs such as Guotai Fund Management Co., Ltd., BOC Wealth Management Co., Ltd. and CCB Wealth Management Co., Ltd. through Central Huijin Investment Co., Ltd., which is the second-tier subsidiary of the State Council.

${ }^{163}$ See Guanyu Wanshan Guoyou Jinrong Ziben Guanli De Zhidao Yijian (关于完 善国有金融资本管理的指导意见) [Guiding Opinions of the CPC Central Committee and the State Council on Improving the Management of State Financial Capital] (promulgated by the State Council, June 30, 2018, effective June 30, 2018); Guoyou Jinrong Ziben Chuzi Ren Zhize Zhan Hang Guiding (国有金融资本出资人 职责暂行规定) [The Interim Provisions on the Duties of State-owned Financial Capital Contributors] (promulgated by the General Office of the State Council, Mar. 9, 2020, effective Nov. 7, 2019); Guoyou Jinrong Ziben Guanli Tiaoli Zhengqiu Yijian Gao (国有金融资本管理条例征求意见稿) [Regulations on the Management of State-owned Financial Capital (Draft for Comments)], (promulgated by MOF May 11, 2020, effective May 11, 2020).

164 "Senior managers" includes directors and supervisors.

${ }^{165}$ See Gongsi Fa (公司法) [Company Law] (promulgated by Order No. 16 of President, adopted at the Sixth Session of the Standing Committee of the $13^{\text {th }}$ National People's Congress on Oct. 26, 2018) Art.37. 
liang hui). Specifically, banks, insurance companies and other institutional investors such as financial asset management companies, trust companies and financing companies are subject to the regulation of CBIRC; whereas securities companies and SIF firms are regulated by CSRC. ${ }^{166}$ In addition, according to the Interim Measures for the Supervision and Administration of Financial Holding Companies, which was issued recently on September 11, 2020, the financial holding companies are subject to the regulation of the PBOC. ${ }^{167}$

Second, for SOIIs which are listed in the Directory of Central Financial Enterprises, the CCP is able to exercise its control through the appointment of their First in Command. ${ }^{168}$ According to the Interim Regulations on the Management of the Leading Personnel of Central Financial Enterprises, which was issued by the General Office of the CCP in 2011, the appointment of the senior managers of central financial enterprises shall be administered by the CCP (which relies on the principle referred to in Chinese as "dang guan gan bu" (which in English can roughly be translated as "the Party administers the management of cadres"). ${ }^{169}$ In addition, for the senior managers in

${ }^{166}$ See Baoxian Gongsi Guanli Guiding (保险公司管理规定), [Provisions on the Administration of Insurance Companies] (promulgated by CIRC Sep. 9, 2009, adopted Oct. 19, 2015); Yinhang Ye Jiandu Guanli Fa (银行业监督管理法) [Banking Supervision Law] (promulgated by the Standing Comm. Nat'l People's Cong., Dec. 27, 2003, adopted at the 24th meeting of the Standing Comm. Nat'1 People's Cong. Oct. 31, 2006); Di Shisan Jie Quanguo Renmin Daibiao Dahui Di Yi Ci Huiyi Guanyu Guownyuan Jigou Gaige Fangan De Jueding (第十三届全国人民 代表大会第一次会议关于国务院机构改革方案的决定) [Decision of the First Session of the Thirteenth National People's Congress on the State Council Institutional Reform Proposal] (adopted at the First Session of the Thirteenth National People's Congress on Mar. 17, 2018); Zhengquan Gongsi Jiandu Guanli Tiaoli(证券公司监督管理条例)[Regulations on the Supervision and Administration of Securities Companies] (promulgated by the State Council April 23, 2008, adopted July 29, 2014); Zhengquan Touzi Jijin Guanli Gongsi Guanli Banfa (证券投资基金 管理公司管理办法) [The Measures for the Administration of Securities Investment Fund Management Companies] (promulgated by CSRC Nov. 1, 2012, effective Nov. 1, 2012).

167 'Financial holding company' refers to limited liability companies or companies limited by shares that are formed according to the law, that control two or more different types of financial institutions, and that only conduct equity investment management and do not directly carry out commercial business activities.

168 See, Zhongyang Jinrong Qiye Minglu (中央金融企业名录) [Directory of Central Financial Enterprises] (promulgated by Finance Department of MOF, Feb. 20, 2021, Feb. 20 ,

2021) http://bgt.mof.gov.cn/zhuantilanmu/rdwyh/czyw/202102/t20210219_3658752.htm ${ }^{169}$ See Zhongguan Jinrong Qiye Lingdao Renyuan Guanli Zanxing Guiding (中管金 融企业领导人员管理暂行规定) [Interim Regulations on the Management of Leading Personnel of Central Financial Enterprises] (promulgated by the General 
SOIIs who are government officials and who are CCP members, they are bound by the Law of the People's Republic of China on Administrative Discipline for Public Officials and related CCP regulations. ${ }^{170}$ These mechanisms ensure that the CCP maintains control over the governance of SOIIs and illustrates how the CCP can effectively exact its control over SOIIs for the purpose of policy channeling.

It is noteworthy that although all the members of the National Team are State-Controlled Institutional Investors, there are many SOIIs in this category that are not part of the National Team. ${ }^{171}$ This makes sense as the National Team merely refers to the SOIIs that were tapped to stabilize the markets in 2015 and is a loose category that appears to evolve based on market circumstances. ${ }^{172}$ In this sense, the National Team is an illustration of how the CCP can quickly and effectively utilize SOIIs for policy channeling and is not a fixed category of institutional investors unto itself.

The second category is State-Influenced Institutional Investors, which includes domestic POIIs in China. As all State-Influenced Institutional Investors are privately owned, unlike in State-Controlled Institutional Investors, the $\mathrm{CCP}$ does not have the ability to directly control POIIs through the exercise of its shareholders' rights and, in

Office of the Chinese Communist Party, Nov. 16, 2011, Article 3, available at https://jjjcz.mee.gov.cn/djfg/dnfgzd/gfxwj/201810/t20181015_693971.html:

The management of the leading personnel of financial enterprises shall adhere to the principle of the Party administers the management of cadres; adhere to the criteria of both virtue and talent and with virtue as the first priority; adhere to democracy, openness, competition and meritocracy; adhere to the unity of rights and responsibilities, incentives and constraints; adhere to the combination of the acceptance of investors, the market and employees; adhere to the law and procedural compliance.

${ }^{170}$ Cheng, supra note 157 , at 25 . It must be noted that strictly speaking, senior managers of SOIIs do not have formal administrative levels or ranks. See Zhonggong Zhongyang Guanyu Guoyou Qiye Gaige He Fazhan Ruogan Zhongda Wenti De Jueding (中共中央关于国有企业改革和发展若干重大问题的决定) [Decision on Several Major Issues Concerning the Reform and Development of State-owned Enterprises] (promulgated by the General Office of the Chinese Communist Party, Sept. 22, 1999, effective September 22, 1999). However, as many of those "First in Command" are appointed and removed by the Organization Department of the CCP, they have an administrative level or rank. It must be noted that not all senior managers of SOIIs are government officials and, therefore, not all of them have to follow the Zhonghua Renmin Gongheguo Gongzhi Renyuan Zhengwu Chufen Fa ( 中华人民共和国公职人员政务处分法) [Law of the People's Republic of China on Administrative Discipline for Public Officials] (promulgated by the Standing Committee of the National People's Congress on June 20, 2020). Only those who were government officials before they joined SOIIs will be subjected to this law.

${ }^{171}$ Ying, supra note 153; See Diagram 1 below.

${ }^{172}$ Ying, supra note153; Cheng, supra note 153; Yang, supra note 156. 
turn, by directly appointing senior managers of SOIIs. Also, the senior managers of POIIs are generally recruited from the private sector and receive market-based salaries, unlike the public regulated salaries of the government officials who compose most of the First in Command in SOIIs. ${ }^{173}$

However, despite the apparent free-market appearance of POIIs, they are categorized as State-Influenced Institutional Investors because of the formal and informal mechanisms that the CCP may use to influence POIIs to engage in policy channeling. In terms of formal power, although the senior managers in POIIs are not directly appointed by the $\mathrm{CCP}$, they are required to be approved by relevant regulatory government agencies (i.e., PBOC, CBIRC or CSRC) before their appointment. As mentioned above, domestic institutional investors are regulated by $\mathrm{PBOC}, \mathrm{CBIRC}$ or CSRC depending on the financial industry that they are a part of. Historically, part of the regulatory power of these three government agencies is derived through their power to approve the appointment of senior managers of POIIs. ${ }^{174}$

Taking SIF firms as an example, normally, every SIF has an Investment Decision Committee (IDC) which is responsible for

${ }^{173}$ Cheng, supra note 157 , at 22. Telephone interview with legal counsel, Ms. C, DBS (Securities) (Mar. 30, 2021) (on file with author).

${ }^{174}$ See Yinhangye Jinrong Jigou Dongshi (Lishi) He Gaoji Guanli Renyuan Renzhi Zige Guanli Banfa (银行业金融机构董事 (理事) 和高级管理人员任职资格管 理办法) [The Measures for the Administration of the Office-holding Qualifications of the Directors and Senior Managers of Banking Financial Institutions] (promulgated by the Banking Regulatory Comm'n, Nov. 18, 2013, effective Dec. 18, 2013), available at http://www.lawinfochina.com/display.aspx?id=15460\&lib=law. Baoxian Gongsi Dongshi, Jianshi He Gaoji Guanli Renyuan Renzhi Zige Guanli Guiding (保险公司董事、监事和高级管理人员任职资格管理规定) [Provisions on the Administration of the Office Qualifications for the Directors, Supervisors and Senior Executives of Insurance Companies] (promulgated by the Ins. Regulatory Comm'n, Jan. 23, 2014, effective January 23, 2014), available at https://plus.lexis.com/api/permalink/a430af2d-e5cb-4862-a076-

cbcdb35199e0/?context=1530671. Zhengquan Gongsi Dongshi, Jianshi He Gaoji Guanli Renyuan Renzhi Zige Jianguan Banfa (证券公司董事、监事和高级管理人 员任职资格监管办法) [Measures for the Supervision and Administration of the Professional Qualifications of Directors, Supervisors and Senior Managers of Securities Companies] (promulgated by the Sec. Regulatory Comm'n, Oct. 20, 2006, revised October 19, 2012) available at http://www.csrc.gov.cn/pub/csrc_en/laws/rfdm/DepartmentRules/201212/t2012120 4_217601.html. Zhengquan Touzi Jijin Guanli Gongsi Gaoji Guanli Renyuan Renzhi Guanli Banfa (证券投资基金管理公司高级管理人员任职管理办法) [The Measures for the Administration of Post-holding of Senior Officers of Securities Investment Fund Management Companies] (promulgated by the Sec. Regulatory Comm'n, Sept. 22, 2004, effective Oct. 1, 2004) available at http://www.lawinfochina.com/display.aspx?id=3737\&lib=law. 
making high level business and policy decisions in the SIF. ${ }^{175}$ The IDC is composed of the SIF firm's senior managers, ${ }^{176}$ which give them an air of independence as they are private sector employees. ${ }^{177}$ Historically, the CSRC had a veto power over the appointment and removal of all IDC members which it could exercise due to the fact that the appointment of all executives of securities companies had to be reported to the CSRC for filing. ${ }^{178}$ Notably, following the new Securities Law, which came into force on March 1, 2020, several laws and regulations were issued to revise the ex-ante approval requirement of the appointment of POIIs' senior managers to only ex-post filing. ${ }^{179}$ However, it is too early to tell whether this will make a difference in the CSRC's actual influence over POIIs. In terms of informal mechanisms, research based on anonymous interviews with senior employees in POIIs suggests that the CSRC uses window guidance to effectively control the selection of senior managers (who are also the

${ }^{175}$ Cheng, supra note 157, at 26. Telephone interview with fund manager, Mr. Y, GF Securities (Mar. 18, 2021) (on file with author).

176 Which generally consists of the principals of management (including the chairman, general manager, chief financial officer). Telephone interview with fund manager, Mr. Y, GF Securities (Mar.18, 2021) (on file with author). Telephone interview with legal counsel, China International Capital Corporation (Mar.30, 2021) (on file with author).

$177 \mathrm{Yu}$ Jin \& Hou Wei Xiang (于瑾 \& 侯伟相), Investment Decision-Making Committee Characteristics and Investment Performance and Ability (投资决策委员 会特征与投资业绩，投资能力一基于公募基金的研究), 6 REV. INV. STUD. (投资 研究) 116 (2017).

${ }^{178}$ Zhengquan Gongsi Lei Baobei Zhiyin (证券公司类报备指引) [Securities Company Filing Guidelines] (promulgated by the Sec. Regulatory Comm'n, Sept. $14, \quad 2015, \quad$ available http://www.csrc.gov.cn/zjhpublicofheb/bszn/201509/t20150914_283941.htm.

${ }^{179}$ See Zhengquan Fa (证券法) [Securities Law] (promulgated by the Standing Comm. Nat'l People's Cong., Dec. 28, 2019, effective Mar. 1, 2020) available at http://www.npc.gov.cn/englishnpc/c23934/202109/9886ca6f805e4663a9a725d6f72 066dd.shtml. Zhengquan Jijin Jingying Jigou Dongshi, Jianshi, Gaoji Guanli Renyuan Ji Congye Renyuan Jiandu Guanli Banfa (Zhengqiu Yijiangao) (证券基金 经营机构董事、监事、高级管理人员及从业人员监督管理办法（征求意见稿 ) ) [The Measures for the Supervision and Administration of Directors, Supervisors, Senior Managers and Practitioners of Securities and Fund Management Institutions (Draft for Comments)] (promulgated by the Sec. Regulatory Comm'n, Nov. 20, 2020) available at http://www.moj.gov.cn/news/content/202011/20/zlk_3260352.html. Jinrong Konggu Gongsi Dongshi, Jianshi, Gaoji Guanli Renyuan Renzhi Beian Guanli Zanxing Guiding (金融控股公司董事、监事、高级 管理人员任职备案管理暂行规定) [The Interim Provisions on the Administration of Recordation for the Office-Holding of Directors, Supervisors, and Senior Executives of Financial Holding Companies] (promulgated by the People's Bank of China, March 31, 2021, effective May 1, 2021) available at https:/www.lawinfochina.com/display.aspx?id=35219\&lib=law. 
IDC members), ${ }^{180}$ and IDCs are often composed of CCP members. ${ }^{181}$ The CSRC's window guidance, combined with its formal veto power, suggests that IDCs provide a conduit for the CCP to pressure POIIs to engage in policy channeling. ${ }^{182}$

However, it must be noted that generally speaking, the IDC would not interfere in the day-to-day investment activities in the SIF, as it normally delegates its authority over investment decisions to the SIF's fund managers. ${ }^{183}$ Research based on anonymous interviews with senior managers in SIFs suggests that under normal circumstances the IDC does not intervene in decisions of fund managers with respect to what stock they choose to purchase nor in how fund managers choose to engage in the corporate governance of investee companies. ${ }^{184}$ The CCP's ability to directly control the dayto-day investment activities in SIFs is limited as fund managers are not within the list of senior managers whose appointments are subject to the approval of the CSRC. ${ }^{185}$ However, as highlighted in Part III, for the purpose of the split share reform the relevant voting decision in investee companies was reallocated from fund managers to the IDC. This illustrates how the CCP can, and has, used its regulatory power and indirect control over IDCs to engage in policy channeling. In addition, senior fund managers in SIFs are licensed by the Securities Association of China (SAC), which is a non-profit organization under the supervision and guidance of the CSRC. ${ }^{186}$ This provides another possible avenue for the CCP to exact pressure on POIIs for the purpose of policy channeling, even when the IDC does not interfere in the decisions of fund managers.

${ }^{180}$ Cheng, supra note157, at 24-25.

${ }^{181}$ Firth et al., supra note 109, at 693.

${ }^{182}$ Mo Shensheng, (莫中生), Financial Restructuring and Economic Development in China from the Perspective of Institutional Arrangement (制度安排视角下的中 国金融结构调整与经济发展) (Ph.D. dissertation, Zhejiang University) (2014)).

${ }^{183}$ Cheng, supra note 157, at 26;. See Zhengquan Touzi Jijin Guanli Gongsi Gongping Jiaoyi Zhidu Zhidao Yijian (证券投资基金管理公司公平交易制度指导 意见) [Guiding Opinions on the Fair Trade Rules for Securities Investment Fund Management Companies] (promulgated by the Sec. Regulatory Comm'n, Aug. 3, 2011, effective Aug. 3, 2011) available at https://plus.lexis.com/api/permalink/7630d5ba-a79e-4042-b5a6b99c1368be2f/?context=1530671.

${ }^{184}$ Cheng, supra note 157 , at 26. Telephone interview with Mr. Z, fund manager, China International Capital Corporation Limited (May 26, 2020). Telephone interview with Ms. X, legal counsel, China International Capital Corporation Limited (Mar. 3, 2021). Telephone interview with Mr. Y, fund manager, GF Securities (Mar. 18, 2021) (on file with author). Telephone interview Ms. C, legal counsel, DBS Securities (China) (Mar. 31, 2021). Telephone interview with Ms. J, senior manager, CMS (Shanghai) (Mar. 30, 2021).

${ }^{185}$ Cheng, supra note 157 , at 24.

${ }^{186}$ Cheng, supra note 157, at 26. 
The third category is Foreign-Owned Institutional Investors (FOIIs), which includes all QFIIs and the other foreign institutional investors described in Part II. As mentioned above, there is no evidence that the CCP uses FOIIs as a mechanism for policy channeling. The senior managers of FOIIs are not required to seek the approval of the CSRC. ${ }^{187}$ Moreover, the person in charge of the QFII's Chinese investments does not have to meet the licensing requirements of the $\mathrm{SAC}$, the only requirement is for them to meet the qualifications for investment professionals in their respective home jurisdictions. ${ }^{188}$ As such, with respect to FOIIs the CCP lacks the direct channels of authority it has over SOIIs and the indirect channels for window guidance it has over POIIs, leaving FOIIs considerably more insulated from the primary mechanisms that the CCP uses to engage in policy channeling, which may provide one reason for the empirical evidence in Part III that they improve corporate governance in their investee companies.

However, based on the evidence concerning FOIIs in Part II, it could be argued that by strategically capping the total amount of investment by FOIIs and their ability to purchase a controlling shareholder stake in A-Shares companies, the CCP has ensured that FOIIs will not be major players in the A-Shares market. Despite the recent relaxation of these restrictions, there is no evidence that the irrelevance of FOIIs in policy channeling will change in the foreseeable future. This comports with the observation made in Part III that Activist Campaigns by FOIIs are extremely rare.

\section{Day-to-Day Corporate Governance Function of Institutional Investors in China}

\footnotetext{
${ }^{187}$ See Hege Jingwai Jigou Touzizhe He Renminbi Hege Jingwai Jigou Touzizhe Jingnei Zhengquan Qihuo Touzi Guanli Banfa (合格境外机构投资者和人民币合 格境外机构投资者境内证券期货投资管理办法) [The Administrative Measures for Securities and Futures Investment Made in China by Qualified Foreign Institutional Investors and RMB Qualified Foreign Institutional Investors] (promulgated by the Sec. Regulation Comm'n, People's Bank of China, and State Admin. of Foreign Exchange, Sept. 25, 2020, effective Nov. 1, 2020) Art. 6:

Whoever applies for the qualification as a qualified foreign investor shall meet the following conditions: ... (2) The principal person in charge of its investment in China satisfies the relevant requirements for practicing qualifications prescribed by the foreign country or region where the applicant is located (if any)...

${ }^{188}$ Cheng, supra note 157, at 26. See Service Guide for Administrative Licensing Matters: Qualified Foreign Investor Qualification Approval (promulgated by the Sec. Regulatory Comm'n, September 25, 2020) available at http://www.csrc.gov.cn/pub/csrc_en/laws/overRule/Announcement/202009/P02020 0925690263056120.pdf.
} 
Equally as important as recognizing the CCP's ability to use institutional investors as a powerful mechanism for policy channeling, is the observation that the CCP appears to use this power only in a selective and targeted manner. In the case of POIIs, as highlighted above, empirical and anecdotal evidence suggests that the CCP's use of policy channeling is reserved to facilitate major reforms, to stabilize the market in times of crisis, or to ensure social stability surrounding major political events. ${ }^{189}$ Based on interviews conducted by one of us in 2020 and 2021, senior employees in POIIs uniformly were of the view that in "normal times" POIIs worked as asset owners and/or asset managers to maximize the returns for their ultimate beneficiaries - and not for policy channeling. ${ }^{190}$ This finding is confirmed by another research project which concluded, based on anonymous interviews of executives in POIIs, that on a day-to-day basis they were driven by free-market forces, and not policy channeling. ${ }^{191}$

We recognize that the answers provided by the employees who were interviewed in POIIs may be self-serving. However, with respect to POIIs, particularly SIFs, this comports with the empirical studies described in Part III demonstrating the positive impact that SIFs tend to have on the performance of A-Shares companies - with the notable exception of the split share reform, which was an extraordinary situation where an important CCP policy objective was involved. ${ }^{192}$ It is also supported by the evidence in Part III of the increasing number of Activist Campaigns by POIIs and, most importantly, that half of the Activist Campaigns carried out against SOEs have been successful. ${ }^{193}$ Although the number of Activist Campaigns has been relatively small, this illustrates that outside of major events and reforms, the CCP has sometimes allowed POIIs to play an active market-based role as institutional investors - even when it involves challenging the corporate governance of SOEs. This suggests that although the CCP may transform POIIs into State-Influenced Institutional Investors, it appears to exercise its power in a targeted manner to achieve specific

\footnotetext{
${ }^{189}$ Shen \& Xie, supra note 153.

190 Telephone interview with Mr. Z, fund manager, China International Capital Corporation Limited (May 26, 2020). Telephone interview with Ms. C, legal counsel, DBS Securities (Mar. 31, 2021). Telephone interview with Ms. J, senior manager, CMS (Mar. 30 2021); Telephone interview with Mr. Y, fund manager, GF Securities (Mar. 18, 2021) (on file with author).

${ }^{191}$ Cheng, supra note 157 , at 24. Telephone interview with $\mathrm{Mr}$. Li, fund manager, China International Capital Corporation (May 26, 2020). Telephone interview with Ms. C, legal counsel, DBS Securities (Mar. 31 2021). Telephone interview with Ms. J, senior manager, CMS (Mar. 30 2021). Telephone interview with Mr. Y, fund manager, GF Securities (Mar. 18, 2021). Telephone interview with Ms. K, partner, Global Law Office (Mar. 30, 2021) (on file with author).

${ }^{192}$ Firth et al., supra note 109, at 697; Huang \& Zhu, supra note 47, at 314.

193 See Appendix 2.
} 
and important policy objectives — with POIIs normally being driven by free-market forces.

In terms of SOIIs, the evidence from Activist Campaigns in Part III also suggests that in normal times SOIIs are driven by freemarket forces to improve the corporate governance of their investee companies. This is suggested by the fact that a majority of Activist Campaigns undertaken in the A-Shares market were conducted by SOIIs. ${ }^{194}$ Interestingly, a significant number of these campaigns targeted SOEs - suggesting that the CCP realizes the corporate governance and economic benefits of having SOIIs serve as a check on the controlling shareholder power of SOEs, which is congruent with the CCP's long-standing policy to support the development of institutional investors as a mechanism to improve corporate governance and stabilize the stock market. ${ }^{195}$ The Activist Campaigns by SOIIs against POEs also suggest that the CCP uses SOIIs as a mechanism to serve as a check on controlling shareholder power more generally. ${ }^{196}$

This comports with the government's creation of the China Securities Investor Services Centre (ISC) - a non-profit organization that owns 100 shares in all A-Shares companies for the purpose of facilitating lawsuits to protect minority shareholders' rights. ${ }^{197}$ As of April 2020, the ISC had facilitated 25 cases by appointing attorneys for the claimant minority shareholders and had successfully filed a lawsuit in its own name to invalidate a corporate resolution in an investee company. ${ }^{198}$ The ISC also acts as a mediator to help resolve corporate governance disputes between institutional investors and investee companies free of charge. ${ }^{199}$ This is congruent with the amendments made to the 2020 Corporate Governance Code, which encourages institutional investors to be actively engaged in the

\footnotetext{
${ }^{194} I d$.

${ }^{195} \mathrm{Id}$.

${ }^{196} \mathrm{Id}$.

${ }^{197}$ Robin Hui Huang, Rethinking the Relationship Between Public Regulation and Private Litigation: Evidence from Securities Class Action in China, 19 THEORETICAL INQUIRIES L. 333, 359 (2018); Cheng, supra note 157, at 20.

${ }^{198}$ Cheng, supra note 157, at 24; China Securities Investor Services Center, Rights Protection Service (中证中小投资者服务中心), http://www.isc.com.cn/html/wqfw/.

${ }^{199}$ Cheng, supra note 157, at 24; Guan Yu Quan Mian Tui Jing Zheng Quan Qi Huo Jiu Feng Duo Yuan Hua Jie Ji Zhi Jian She De Yi Jian De Tong Zhi (关于全面推进 证券期货纠纷多元化解机制建设的意见的通知) [Notice on Comprehensively Advancing Establishment of Diversified Resolution Mechanism of Securities and Futures Disputes], (promulgated by the Supreme People's Court of PRC and the China Securities Regulatory Commission on Nov. 13, 2018), [2018] No. 305 of the SPC.
} 
corporate governance of their investee companies. ${ }^{200}$ As highlighted in Part II, this is unsurprising based on the long history of the CCP promoting the development of institutional investors as a mechanism to stabilize the market and improve corporate governance. It also provides strong evidence that on a day-to-day basis-outside of extraordinary political and market events - the CCP not only allows, but encourages, institutional investors to be actively engaged shareholders driven primarily by free-market forces.

Finally, to be clear, we are not suggesting that the system is perfectly bifurcated between SOIIs/POIIs always serving as an effective mechanism for policy channeling in extraordinary times and always being an efficient corporate governance mechanism on a dayto-day basis. Empirical studies in Part III suggest that in some instances SOIIs may be less effective than POIIs and/or FOIIs in monitoring investee companies. ${ }^{201}$ In other instances, empirical evidence suggests that SOEs may be more insulated against corporate governance pressure from institutional investors than POEs. ${ }^{202}$ This suggests that sometimes, on a day-to-day basis, the lack of independence from the government may blunt the effectiveness of SOIIs and shield SOEs from effective monitoring by institutional investors. This may be more likely to occur when the circumstances in a given case elevate a corporate governance issue into an issue of political importance to the CCP. However, based on the totality of the empirical, case study, and interview evidence, it is our view that this stylized picture of the CCPs formal and informal targeted use of policy channeling (or lack thereof), as depicted in Diagram 1, largely approximates what plays out in practice.

\footnotetext{
${ }^{200}$ See supra Part II (Principle 11 of the Chinese Corporate Governance Code)

${ }^{201}$ See supra Part III.

202 See supra Part III.
} 
Diagram 1: Network of Influence over Institutional Investors in China $^{203}$

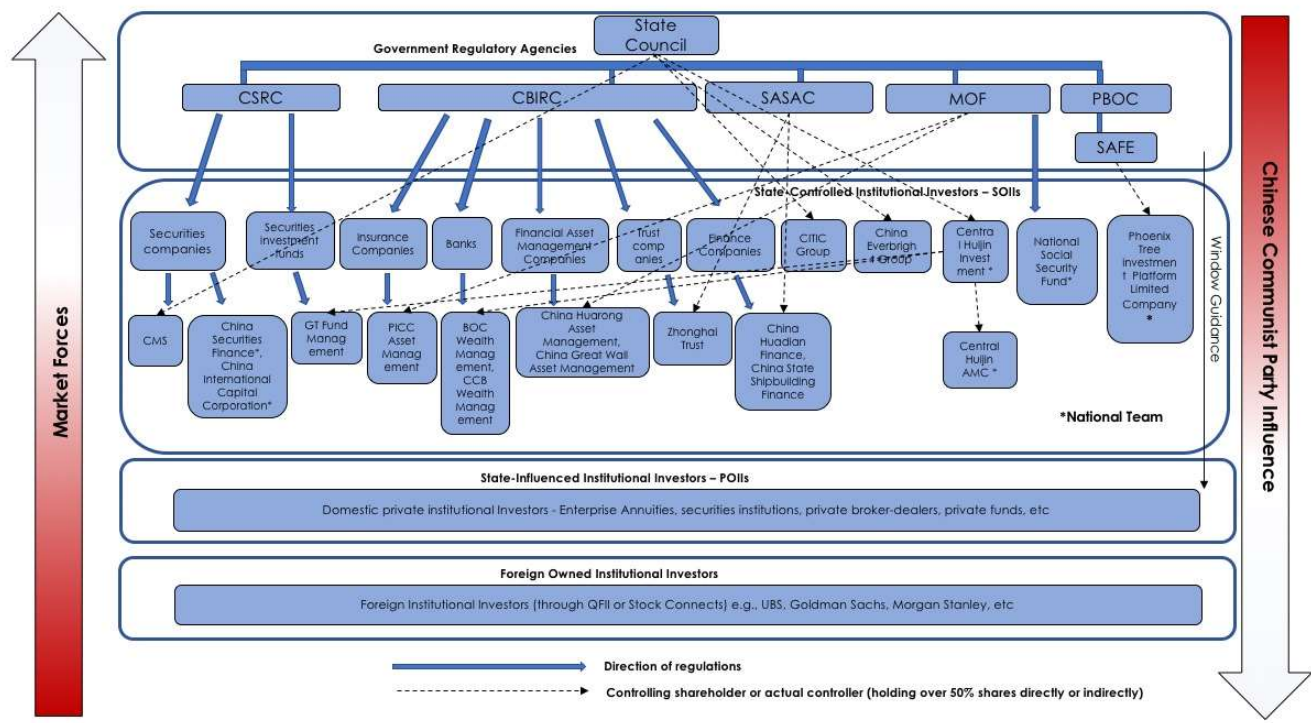

${ }^{203}$ Institutional investors in Diagram 1 include general legal persons and non-legalperson enterprises, domestic professional institutional investors and foreign institutional investors, see supra Chart 3. 


\section{InSTITUTIONAL INVESTORS IN CHINA: THE MARKET WithIN THE STATE}

Institutional investors have clearly become an important feature of Chinese corporate governance that can no longer be ignored. This Article takes the first step, in what will likely require an academic marathon, to gain an accurate understanding of the role that institutional investors play in China's unique model of corporate governance. From a broader perspective, there are three general observations that can be drawn from the rise of institutional investors in China.

First, the rise of institutional investors does not portend the rise of an Anglo-American system of corporate governance or Westernstyle capitalism. At first blush, the rise in institutional investors may suggest that China is converging on the Anglo-American model of corporate governance, with institutional investors at its core. However, if the percentage of the A-Shares market controlled by institutional investors continues to rise, what will arise will be uniquely Chinese. The primary reason for this, as has been shown, is that the CCP will maintain its ultimate control over most institutional investors-a unique feature of the China Model without an equivalent in AngloAmerican corporate governance.

Second, the complexity of China's regulation of institutional investors and its government-centered system of corporate governance requires further analysis. This Article identifies the varieties of institutional investors in China and maps out the various government bodies, regulations, and tactics that provide the $\mathrm{CCP}$ with the ability to use SOIIs and POIIs as mechanisms for policy channeling. It also demonstrates that institutional investors, on a day-to-day basis, increasingly appear to work as an effective mechanism to improve corporate governance. However, a more detailed understanding of the functioning of each of the varieties of institutional investors - which may be more suitable for a book than an article-would add greater insight into China's increasingly atomized market for institutional investors. Also, the role played by institutional investors in China's autochthonous government-controlled system of corporate governance-with the unique internal checks and balances suggested by SOIIs successfully engaging in Activist Campaigns against SOEsis a promising avenue for future research.

Third, the complexity of China's regulation of institutional investors and the unique model of corporate governance it has created do not paint a picture of the CCP micro-managing corporate governance in the way that some notions of "state capitalism" may 
suggest. ${ }^{204}$ Rather, it appears that, on a day-to-day basis, the Chinese government purposefully allows the free market to govern the relationship between institutional investors and companies even when it has ultimate control over both. However, when there is a need to push through a major reform, stabilize the market, or maintain calm in society for important political reasons, institutional investors are used as an effective mechanism for the CCP to engage in policy channeling. This suggests that the free market is the de facto norm and that the CCP uses its power to intervene in a targeted manner. Rather than suggesting that China is governed by "state capitalism," where SOEs have the dominant position in major industries, ${ }^{205}$ our analysis of institutional investors seems to suggest that China is better described as a system defined by "the market within the state," where the free market and the state coexist, and the free market functions within the boundaries set by the state. ${ }^{206}$

204 Telephone interview, May 30, 2021, Partner, Global Law Office (Beijing); Telephone interview, May 30, 2021, Investment manager, CMS (Shanghai); Telephone interview, May 30, 2021, Legal Counsel, DBS Securities (China); Telephone interview, May 30, 2021, Investment manager, CICC (Shenzhen). See also, Wang Feng(王丰), The Definition of Socialist Market Economy with Chinese Characteristics-Based on the Critique of “Neo-State Capitalism” (中国特色社会 主义市场经济的界说——基于对 “新国家资本主义” 的批判), 28 J. MGMT. (管 理学刊) 15, 17 (2015).

205 The Rise of State Capitalism: The Emerging World's New Model, THE ECONOMIST (Jan. 21, 2012), https:/www.economist.com/leaders/2012/01/21/therise-of-state-capitalism.

206 Yongnian Zheng and Yanjie Huang, Market IN State: The Political ECONOMY OF DOMINATION IN CHINA, 29, 31-32 (2018). 
APPENDICES

Appendix 1: Legal Developments and the Government's Role in Developing Institutional Investors in China 1978-2020207

\begin{tabular}{|c|c|c|}
\hline Dates & Law/Policy & Implications and Significance \\
\hline \multicolumn{3}{|c|}{ ALL INSTITUTIONAL INVESTORS } \\
\hline 2002 & $\begin{array}{l}\text { The China Securities } \\
\text { Regulatory Commission and } \\
\text { State Economic and Trade } \\
\text { Commission promulgated } \\
\text { the "Code of Corporate } \\
\text { Governance for Listed } \\
\text { Companies in China." }\end{array}$ & $\begin{array}{l}\text { China designated institutional investors as an } \\
\text { important feature of its corporate governance } \\
\text { system by affirming in its inaugural Corporate } \\
\text { Governance Code that "institutional investors } \\
\text { shall play a role in the appointment of company } \\
\text { directors, the compensation and supervision of } \\
\text { management and major decision-making } \\
\text { processes." }\end{array}$ \\
\hline 2018 & $\begin{array}{l}\text { Revised Code of Corporate } \\
\text { Governance }\end{array}$ & $\begin{array}{l}\text { Chapter } 7 \text { concerning institutional investors } \\
\text { and other related institutions has been added } \\
\text { into the Revised Code. Article } 78 \text { encourages } \\
\text { institutional investors such as the managers of } \\
\text { social security funds, enterprise annuities, } \\
\text { insurance funds, public funds, and other } \\
\text { investment entities under the supervisory and } \\
\text { regulatory remits of national financial } \\
\text { regulatory authorities, to engage in corporate } \\
\text { governance reasonably by exercising their } \\
\text { shareholder rights such as voting rights, } \\
\text { inquiry rights, and advisory rights in } \\
\text { accordance with laws. Article } 79 \text { states that } \\
\text { institutional investors may play an active role } \\
\text { in corporate governance by participating in } \\
\text { decision-making on major issues, } \\
\text { recommending candidates for directors and } \\
\text { supervisors, and supervising the performance } \\
\text { of directors and supervisors in accordance } \\
\text { with laws and regulations and the company's } \\
\text { articles of association. Article } 82 \text { highlights } \\
\text { that minority investors protection agencies } \\
\text { should play an active role in the governance } \\
\text { of listed companies and protect the legitimate } \\
\text { rights and interests of minority investors } \\
\text { through "holding shares for exercising rights" } \\
\text { and other channels. }\end{array}$ \\
\hline \multicolumn{3}{|c|}{ DOMESTIC INSTITUTIONAL INVESTORS } \\
\hline \multicolumn{3}{|c|}{ Securities Investment Funds } \\
\hline $1985-1990$ & $\begin{array}{l}\text { China's domestic financial } \\
\text { institutions cooperated with } \\
\text { overseas financial } \\
\text { institutions, launching a } \\
\text { "China investment fund". } \\
\end{array}$ & $\begin{array}{l}\text { With the injection of overseas funds into the } \\
\text { Chinese investment fund, it stimulated the } \\
\text { development of the domestic investment fund } \\
\text { industry. }{ }^{208}\end{array}$ \\
\hline
\end{tabular}

${ }^{207}$ This table seeks to highlight the most important legal developments in relation to the development of institutional investors in China.

${ }^{208}$ Liu, supra note 67. 


\begin{tabular}{|c|c|c|}
\hline Dates & Law/Policy & Implications and Significance \\
\hline 14 Nov. 1997 & $\begin{array}{l}\text { The State Council } \\
\text { promulgated the "Interim } \\
\text { Measures on the } \\
\text { Management of Securities } \\
\text { Investment Funds" (证券投 } \\
\text { 资基金管理暂行办法). }\end{array}$ & $\begin{array}{l}\text { Regulators started to regulate Securities } \\
\text { Investment Funds in China. } \\
\text { Jin Tai Fund and Kai Yuan Fund became the } \\
\text { first two regulated funds permitted under the } \\
\text { Measures. } \\
\text { The "Old Ten" fund management companies } \\
\text { were established between 1998-1999, } \\
\text { comprising of } 10 \text { companies, including the } \\
\text { China Southern Fund Management, Guotai } \\
\text { Fund Management, China Fund Management. } \\
\text { At the beginning of March 1999, the CSRC } \\
\text { began the process of standardizing and } \\
\text { liquidating the } 75 \text { funds that were established } \\
\text { prior to the Measures in order to bring them in } \\
\text { line with the Measures. By the end of } \\
\text { September 2003, these } 75 \text { funds were } \\
\text { consolidated into } 29 \text {. }\end{array}$ \\
\hline Sept. 2001 & $\begin{array}{l}\text { China's first open-ended } \\
\text { securities investment fund, } \\
\text { Hua-an Innovation } \\
\text { Investment Fund, came into } \\
\text { existence. This marked the } \\
\text { start of a new era, where } \\
\text { public offering funds began } \\
\text { to adopt an open-ended fund } \\
\text { model. }\end{array}$ & $\begin{array}{l}\text { By the end of } 2002 \text {, the number of open- } \\
\text { ended securities investment funds had } \\
\text { increased to } 17 \text {, and it went on to gradually } \\
\text { replace closed-ended funds as opened-ended } \\
\text { funds had more advantages. This period was } \\
\text { also the norming stage for the industry. }\end{array}$ \\
\hline 28 Oct. 2003 & $\begin{array}{l}\text { The "PRC Securities } \\
\text { Investment Fund Law" (证 } \\
\text { 券投资基金法) was } \\
\text { promulgated and } \\
\text { implemented. }\end{array}$ & $\begin{array}{l}\text { This law accelerated the development of } \\
\text { securities investment funds. } \\
\text { By the end of } 2003 \text {, there were three money } \\
\text { market funds in China. However, as of } 2005 \text {, } \\
\text { fund management companies still had little } \\
\text { influence in the capital market because the size } \\
\text { of the industry remained relatively small, and } \\
\text { the strategy it adopted, value investing, was yet } \\
\text { to be widely accepted. }\end{array}$ \\
\hline
\end{tabular}




\begin{tabular}{|c|c|c|}
\hline Dates & Law/Policy & Implications and Significance \\
\hline 27 Apr. 2018 & $\begin{array}{l}\text { The Guiding Opinions on } \\
\text { Regulating the Asset } \\
\text { Management Business of } \\
\text { Financial Institutions (No. } \\
106 \text { [2018] of the People's } \\
\text { Bank of China) (关于规范 } \\
\text { 金融机构资产管理业务的 } \\
\text { 指导意见) was promulgated } \\
\text { by PBOC, CBIRC, CSRC, } \\
\text { and SAFE. }\end{array}$ & $\begin{array}{l}\text { The opinion standardized the regulation of } \\
\text { securities investment funds under the unified } \\
\text { supervision of the People's Bank of China, the } \\
\text { China Banking and Insurance Regulatory } \\
\text { Commission, and the CSRC. } \\
\text { The Guidelines unified regulation standards } \\
\text { for all asset management products issued by an } \\
\text { asset management business such as financial } \\
\text { services provided by banks, trusts, securities } \\
\text { companies, funds, futures companies, } \\
\text { insurance asset management institutions, or } \\
\text { financial asset investment companies. The } \\
\text { Guidelines regulate the risks present in various } \\
\text { aspects of the asset management business, such } \\
\text { as product nesting, capital pool operations, } \\
\text { non-standard asset investment, rigid } \\
\text { repayment, and the disorderly business } \\
\text { operation of non-financial institutions. }\end{array}$ \\
\hline 6 Jan. 2020 & $\begin{array}{l}\text { Guiding Opinions of the } \\
\text { China Banking and } \\
\text { Insurance Regulatory } \\
\text { Commission on Promoting } \\
\text { the High-quality } \\
\text { Development of Banking } \\
\text { and Insurance Industries } \\
\text { (中国银保监会关于推进 } \\
\text { 银行业和保险业高质量发 } \\
\text { 展的指导意见) were issued. }\end{array}$ & $\begin{array}{l}\text { Foreign-funded banks are encouraged to } \\
\text { collaborate with their parent banks in the } \\
\text { featured business, including the wealth } \\
\text { management business. Foreign financial } \\
\text { institutions are encouraged to make equity } \\
\text { investment(s) in the wealth management } \\
\text { subsidiaries of commercial banks. Foreign } \\
\text { asset management institutions are allowed to } \\
\text { set up foreign-controlled joint venture wealth } \\
\text { management companies with subsidiaries of } \\
\text { domestic funded banks or insurance } \\
\text { companies. }\end{array}$ \\
\hline \multicolumn{3}{|c|}{ National Social Security Fund (NSSF) } \\
\hline Aug. 2000 & The NSSF was established. & \\
\hline 2011 & $\begin{array}{l}\text { China's basic pension fund } \\
\text { officially entered the } \\
\text { market. } 210\end{array}$ & $\begin{array}{l}\text { With the approval of the State Council, the } \\
\text { NSSF was entrusted with the investment } \\
\text { operations of the basic pension funds of } \\
\text { Guangdong and Shandong province in } 2012 \\
\text { and } 2015 \text { respectively, each valued at RMB } \\
100 \text { billion, and has achieved high rates of } \\
\text { return. }{ }^{211}\end{array}$ \\
\hline
\end{tabular}

${ }^{210}$ Capital Markets Institute of SSE (上海证券交易所资本研究院)，Study on the Development of Long-Term Funds and their Entry into the Market (长期资金发展 现状及入市问题研究), SSE Research Reports (上证研报), at 1, 5 (2019), http://www.sse.com.cn/aboutus/research/report/c/4800716.pdf. ${ }^{211}$ Id. 


\begin{tabular}{|c|c|c|}
\hline Dates & Law/Policy & Implications and Significance \\
\hline 23 Aug. 2015 & $\begin{array}{l}\text { The State Council } \\
\text { promulgated the "Measures } \\
\text { for the Administration of } \\
\text { Investment in Basic Pension } \\
\text { Insurance Funds" (基本养 } \\
\text { 老保险基金投资管理办 } \\
\text { 法). }\end{array}$ & $\begin{array}{l}\text { The measures broadened the scope of } \\
\text { investment for the funds, stipulating that the } \\
\text { proportion of investment in stocks, stock } \\
\text { funds, hybrid funds, and stock pension } \\
\text { products should not be higher than } 30 \% \text { of the } \\
\text { net asset value of the funds, and allowing the } \\
\text { funds to participate in the trading of stock } \\
\text { index futures and treasury bond futures for the } \\
\text { purpose of value preservation. }\end{array}$ \\
\hline 1 May 2016 & $\begin{array}{l}\text { The NSSF is required to } \\
\text { comply with the "Regulation } \\
\text { on the National Social } \\
\text { Security Fund" (全国社会 } \\
\text { 保 险 基 金 条 例 ) } \\
\text { (“Regulation"), which came } \\
\text { into force on } 1 \text { May } 2016 .\end{array}$ & $\begin{array}{l}\text { The Regulation consists of clear rules for the } \\
\text { asset management of the NSSF, regarding the } \\
\text { financing, management, and use of the fund. } \\
\text { On top of the Regulation, the NSSF is also } \\
\text { required to comply with the PRC Social } \\
\text { Insurance Law, the Interim Provisions on the } \\
\text { Administration of Investment by the National } \\
\text { Social Security Fund ("Interim Provisions"), } \\
\text { the Interim Provisions on the Administration } \\
\text { of Overseas Investment by the National Social } \\
\text { Security Fund, and any other relevant } \\
\text { documents approved by the State Council, the } \\
\text { Ministry of Finance and the Ministry of } \\
\text { Human Resources and Social Security in its } \\
\text { operation and investment of the SSF. }\end{array}$ \\
\hline Nov. 2016 & $\begin{array}{l}\text { The State announced the } \\
\text { four custodians of the } \\
\text { pension funds, namely, the } \\
\text { Industrial and Commercial } \\
\text { Bank of China, the Bank of } \\
\text { China, the Bank of } \\
\text { Communications, and the } \\
\text { China Merchants Bank. }\end{array}$ & \\
\hline \multicolumn{3}{|c|}{ Insurance Fund } \\
\hline 1 Oct. 2009 & $\begin{array}{l}\text { The revised Insurance Law } \\
\text { of the People's Republic of } \\
\text { China came into force. }\end{array}$ & $\begin{array}{l}\text { The revised Insurance Law significantly } \\
\text { expanded the scope of investments permitted } \\
\text { for insurance companies in China. }\end{array}$ \\
\hline 30 July 2010 & $\begin{array}{l}\text { The CIRC promulgated the } \\
\text { "Temporary Measures for } \\
\text { the Administration of the } \\
\text { Utilization of Insurance } \\
\text { Funds" (保险资金运用管理 } \\
\text { 暂行办法). }\end{array}$ & Provided guidance for using insurance funds. \\
\hline 5 Sept. 2010 & $\begin{array}{l}\text { The CIRC issued “Interim } \\
\text { Measures for Equity } \\
\text { Investment with Insurance } \\
\text { Funds”(保险资金投资股 } \\
\text { 权暂行办法). }\end{array}$ & $\begin{array}{l}\text { Insurance funds were allowed to make equity } \\
\text { investments. }\end{array}$ \\
\hline
\end{tabular}




\begin{tabular}{|c|c|c|}
\hline Dates & Law/Policy & Implications and Significance \\
\hline 19 Feb. 2014 & $\begin{array}{l}\text { The Notice of the China } \\
\text { Insurance } \\
\text { Commission } \\
\text { Strengthening on } \\
\text { Improving the Proportional } \\
\text { Regulation of the Utilization } \\
\text { of Insurance Funds (关于加 } \\
\text { 强和改进保险资金运用比 } \\
\text { 例监管的通知) was issued } \\
\text { by CIRC. }\end{array}$ & $\begin{array}{l}\text { The notice raised the limit of the proportion of } \\
\text { the assets of insurance funds invested in equity } \\
\text { assets from } 25 \% \text { to } 30 \% \text {. This amendment } \\
\text { allowed insurance funds to invest more in the } \\
\text { securities market to maximize their profits. By } \\
\text { the end of } 2019 \text {, the outstanding balance of } \\
\text { insurance funds had reached RMB } 18.5 \text { trillion, } \\
13.15 \% \text { of which was invested in stocks and } \\
\text { funds. }\end{array}$ \\
\hline 27 Jan. 2018 & $\begin{array}{l}\text { The Measures for the } \\
\text { Administration of the } \\
\text { Utilization of Insurance } \\
\text { Funds (保险资金运用管理 } \\
\text { 办法) was issued by CIRC. }\end{array}$ & $\begin{array}{l}\text { These measures expanded the scope of } \\
\text { investment by insurance funds, including } \\
\text { investment into securitization products, setting } \\
\text { up private funds by insurance asset } \\
\text { management firms, investment into the venture } \\
\text { capital sector. }\end{array}$ \\
\hline \multicolumn{3}{|c|}{ FOREIGN INSTITUTIONAL INVESTORS } \\
\hline 5 Nov. 2002 & 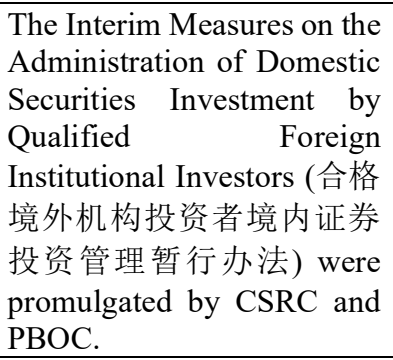 & $\begin{array}{l}\text { Foreign investors must comply with this } \\
\text { measure in order to make investment in } \\
\text { China's securities market. }\end{array}$ \\
\hline 4 May 2011 & $\begin{array}{l}\text { Guidelines on the } \\
\text { Participation of Qualified } \\
\text { Foreign Institutional } \\
\text { Investors in Stock Index } \\
\text { Futures Trading (合格境外 } \\
\text { 机构投资者参与股指期货 } \\
\text { 交易指引) were issued by } \\
\text { the CSRC. }\end{array}$ & $\begin{array}{l}\text { QFIIs participating in stock index futures } \\
\text { trading may only conduct hedging transactions } \\
\text { pursuant to the relevant provisions of the China } \\
\text { Financial Futures Exchange (CFFE). In } \\
\text { addition, both the value of stock index futures } \\
\text { contracts held by a QFII at the end of any } \\
\text { trading day and the trading amount of stock } \\
\text { index futures (except closing positions) of it } \\
\text { during any trading day shall not exceed its } \\
\text { investment quotas, thus preventing short- } \\
\text { selling. }\end{array}$ \\
\hline
\end{tabular}

${ }^{212}$ CBIRC, supra note 79. 


\begin{tabular}{|c|c|c|}
\hline Dates & Law/Policy & Implications and Significance \\
\hline 10 June 2018 & $\begin{array}{l}\text { The Provisions on the } \\
\text { Foreign Exchange } \\
\text { Administration of Domestic } \\
\text { Securities Investment by } \\
\text { Qualified Foreign } \\
\text { Institutional Investors (合格 } \\
\text { 境外机构投资者境内证券 } \\
\text { 投资外汇管理规定) were } \\
\text { issued by the SAFE. }\end{array}$ & $\begin{array}{l}\text { The state shall conduct quota management of } \\
\text { QFIIs' domestic securities investment, and the } \\
\text { investment quota of a single QFII shall be } \\
\text { subject to the recording and approval by the } \\
\text { SAFE. QFIIs may, after obtaining the } \\
\text { qualification license from the CSRC, obtain an } \\
\text { investment quota of not more than a certain } \\
\text { proportion ("basic quota") of its asset size or } \\
\text { the size of securities assets managed by it } \\
\text { "'asset size"). Any application for an } \\
\text { investment quota beyond the basic quota must } \\
\text { be subject to approval by the SAFE. The } \\
\text { investment quota of a foreign sovereign fund, } \\
\text { central bank, monetary authority, or other } \\
\text { institution shall not be subject to the restriction } \\
\text { of the proportion of asset size, and such } \\
\text { institution may obtain a corresponding } \\
\text { investment quota based on its needs for } \\
\text { investment in the domestic securities market. } \\
\text { The standards for the basic quota of a QFII are } \\
\text { as follows: (1) If the assets of (or assets } \\
\text { managed by) a QFII or the group to which it is } \\
\text { affiliated are mainly outside China, the } \\
\text { formula for calculating the basic quota is: USD } \\
100 \text { million + average asset size in the last } \\
\text { three years * } 0.2 \% \text { - obtained quota for RMB } \\
\text { qualified foreign institutional investors (in } \\
\text { USD, hereinafter referred to as the "RQFII } \\
\text { quota"); ( } 2 \text { ) If the assets of (or assets managed } \\
\text { by) a QFII or the group to which it is affiliated } \\
\text { are mainly within China, the formula for } \\
\text { calculating the basic quota is: RMB five billion } \\
\text { or its equivalent + asset size in the last year * } \\
80 \% \text { obtained RQFII quota (in USD); ( } 3 \text { ) } \\
\text { The basic quota shall not exceed USD five } \\
\text { billion (including institutions such as foreign } \\
\text { sovereign funds, central banks, and monetary } \\
\text { authorities); ( } 4 \text { ) The basic quota shall not be } \\
\text { less than USD } 20 \text { million. }\end{array}$ \\
\hline 10 Sept. 2019 & $\begin{array}{l}\text { The SAFE announced its } \\
\text { decision to abolish the } \\
\text { investment quota system } \\
\text { under the QFII and RQFII } \\
\text { Schemes pursuant to the } \\
\text { approval of the State } \\
\text { Council. Moreover, the } \\
\text { restrictions on the pilot } \\
\text { countries and regions under } \\
\text { the RQFII Scheme were } \\
\text { removed. }\end{array}$ & $\begin{array}{l}\text { This decision marked a major step taken by the } \\
\text { SAFE to deepen the reform and opening-up of } \\
\text { the Chinese financial market. }\end{array}$ \\
\hline
\end{tabular}




\begin{tabular}{|c|c|c|}
\hline Dates & Law/Policy & Implications and Significance \\
\hline 7 May 2020 & $\begin{array}{l}\text { The PBOC and the SAFE } \\
\text { issued the Regulations on } \\
\text { Funds of Securities and } \\
\text { Futures Investment by } \\
\text { Foreign Institutional } \\
\text { Investors (境外机构投资者 } \\
\text { 境内证券期货投资资金管 } \\
\text { 理规定). }\end{array}$ & $\begin{array}{l}\text { The Regulations have clarified and simplified } \\
\text { the management requirements for QFIIs' } \\
\text { investments in securities and futures in China, } \\
\text { thus facilitating the further participation of } \\
\text { foreign investors in China's financial market. } \\
\text { The key points of the Regulations include: (1) } \\
\text { Restrictions on investment quota of the QFII } \\
\text { and RQFII have been scrapped and replaced by } \\
\text { registration-based rules for QFIIs to register } \\
\text { their cross-border funds transfer and currency } \\
\text { exchange with the SAFE; (2) Integrated } \\
\text { management will be implemented for both } \\
\text { Renminbi and foreign currencies and QFIIs are } \\
\text { given the freedom to choose which currency } \\
\text { and when they remit money into the country; } \\
\text { (3) The procedures for QFIIs' outward } \\
\text { remittance have been significantly simplified } \\
\text { as Tax Commitment Letters signed by QFIIs } \\
\text { will replace previously required documents } \\
\text { including the special audit reports on } \\
\text { investment returns and tax clearance or tax } \\
\text { filing certificates issued by Chinese certified } \\
\text { public accountants; (4) The limit on the } \\
\text { number of custodians is lifted, allowing a } \\
\text { single QFII to entrust multiple domestic } \\
\text { custodians and appoint one of them as the main } \\
\text { custodian; (5) Foreign exchange risk and } \\
\text { investment risk management mechanism for } \\
\text { QFIIs' domestic securities investment will be } \\
\text { further enhanced. }\end{array}$ \\
\hline
\end{tabular}


Appendix 2: Representative Activism Cases by Institutional Investors in China (1994-Present) ${ }^{213}$

\begin{tabular}{|c|c|c|c|c|c|c|c|c|}
\hline 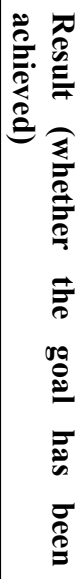 & 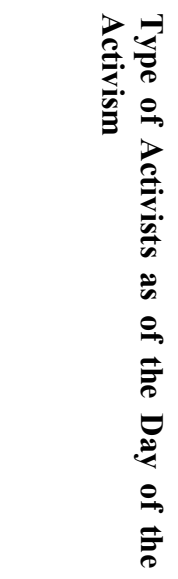 & 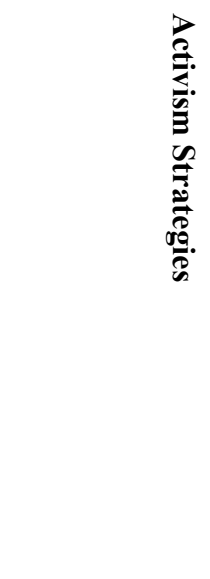 & 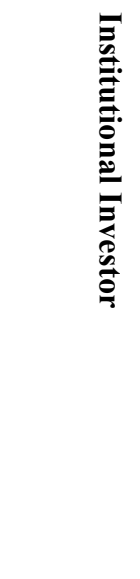 & $\begin{array}{l}\Omega \\
\stackrel{0}{0}\end{array}$ & 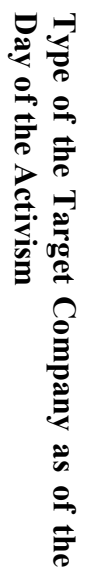 & 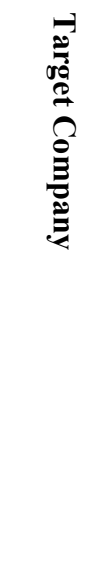 & $\begin{array}{l}\nwarrow \\
\stackrel{8}{=}\end{array}$ & $\prod_{0}^{Z}$ \\
\hline $\begin{array}{l}\text { T. } \\
\text { : } \\
\text { : }\end{array}$ & 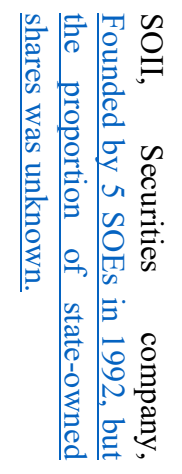 & 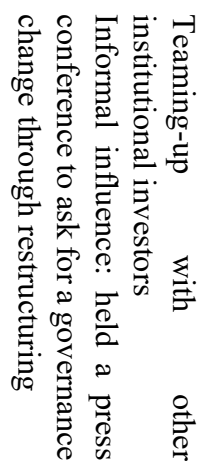 & 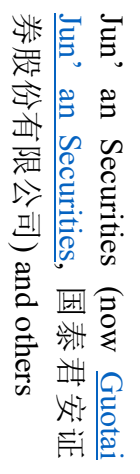 & 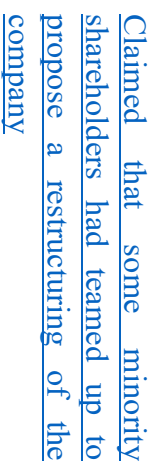 & อ & 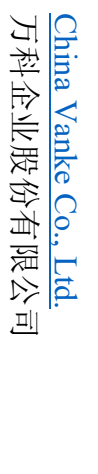 & $\begin{array}{l}\vec{\circ} \\
\triangleright\end{array}$ & - \\
\hline 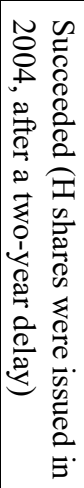 & 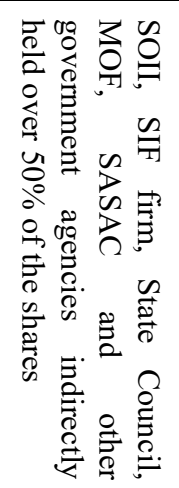 & 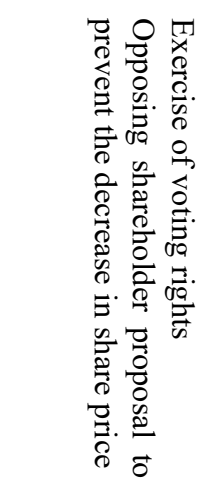 & 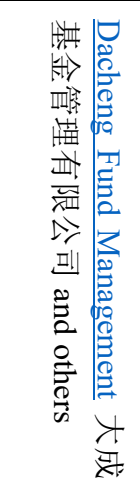 & 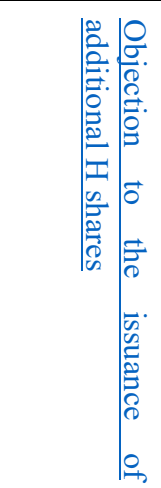 & $\underset{\mathrm{O}}{\mathrm{O}}$ & 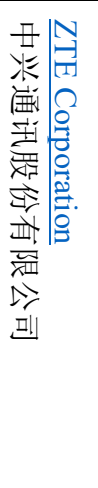 & $\begin{array}{l}\text { No } \\
\text { \& }\end{array}$ & $N$ \\
\hline
\end{tabular}

${ }^{213}$ Institutional investors in Appendix 2 include general legal persons and non-legalperson enterprises, domestic professional institutional investors and foreign institutional investors, see supra Chart 3. 


\begin{tabular}{|c|c|c|c|c|c|c|c|c|}
\hline $\begin{array}{l}\frac{T}{2} \\
\stackrel{2}{0} \\
\stackrel{2}{0}\end{array}$ & 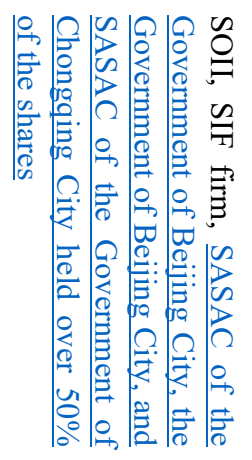 & 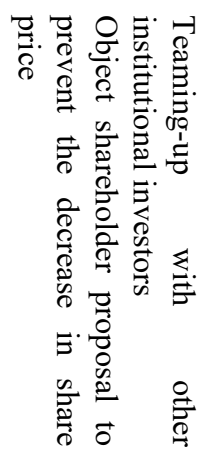 & 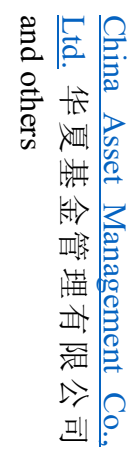 & 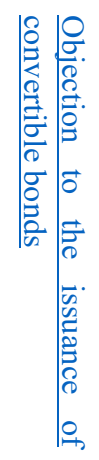 & 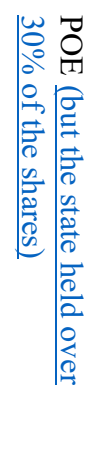 & 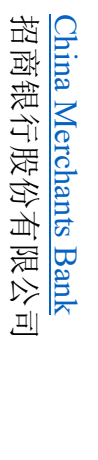 & 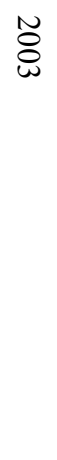 & $\omega$ \\
\hline 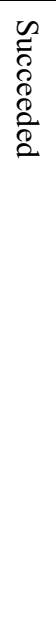 & 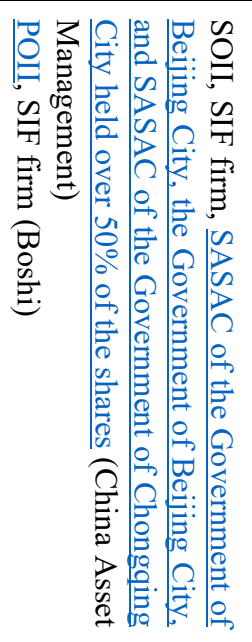 & 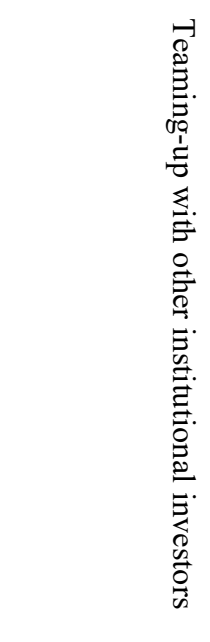 & 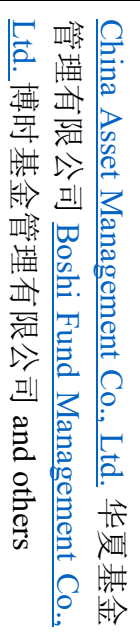 & 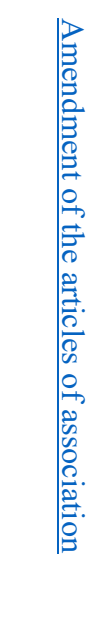 & 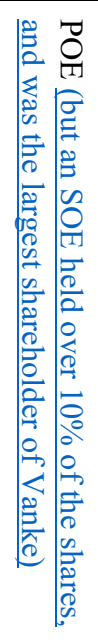 & 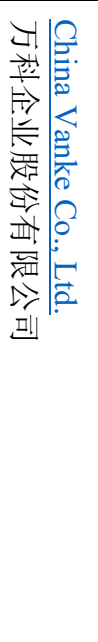 & 苂 & $\Delta$ \\
\hline 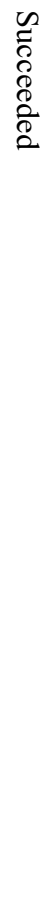 & 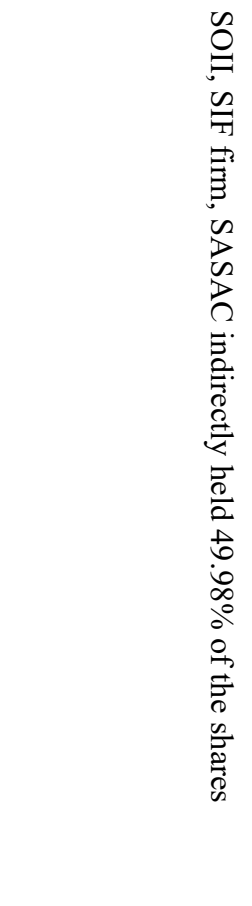 & 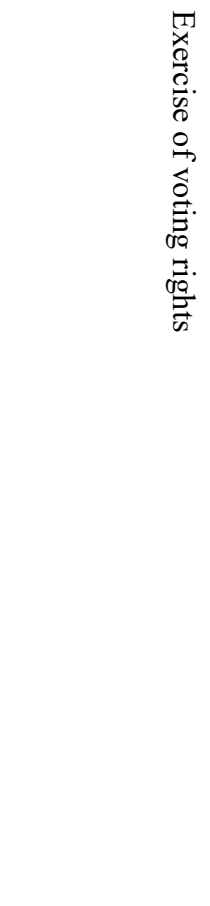 & 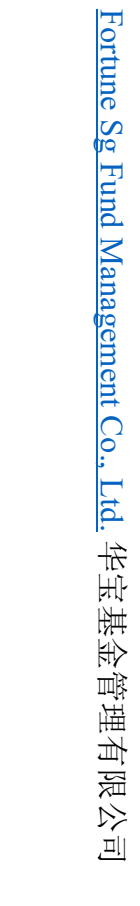 & 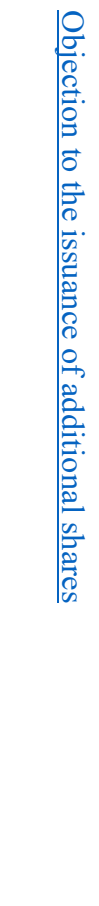 & 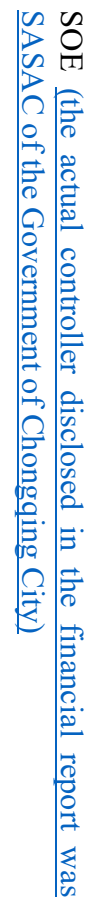 & 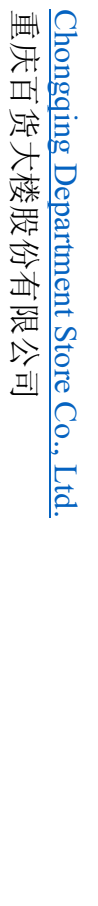 & & ur \\
\hline
\end{tabular}




\begin{tabular}{|c|c|c|c|c|c|c|c|c|}
\hline 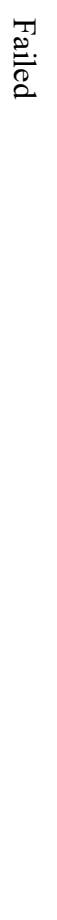 & 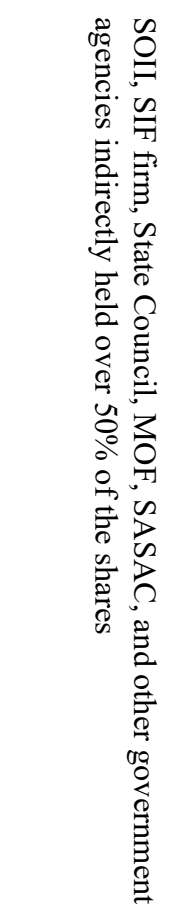 & 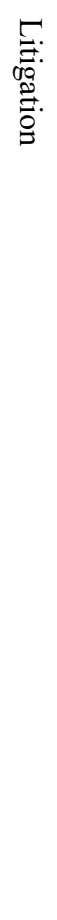 & 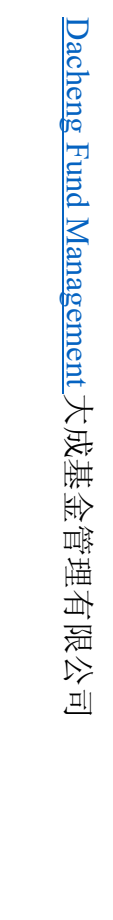 & 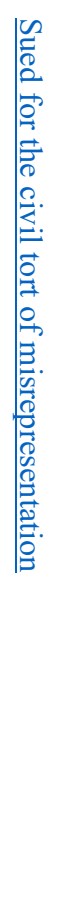 & $\stackrel{0}{0}$ & 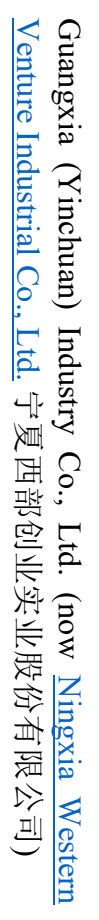 & : & $a$ \\
\hline $\begin{array}{l}\frac{T}{2} \\
\stackrel{2}{\stackrel{D}{2}}\end{array}$ & 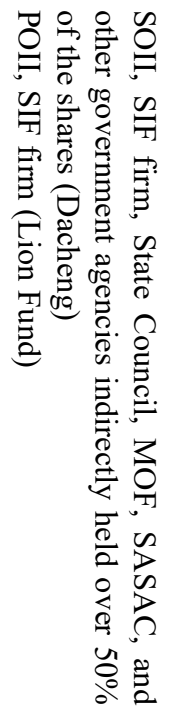 & 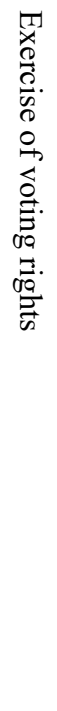 & 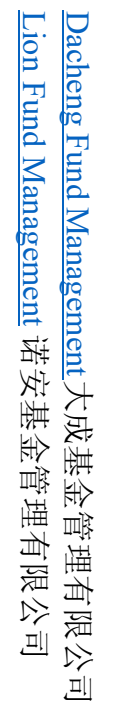 & 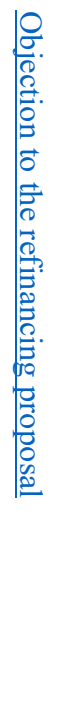 & 恿 & 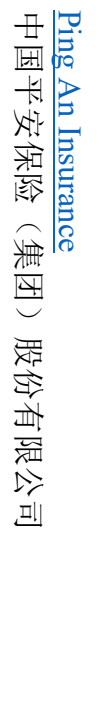 & No & $v$ \\
\hline
\end{tabular}




\begin{tabular}{|c|c|c|c|c|c|c|c|c|}
\hline 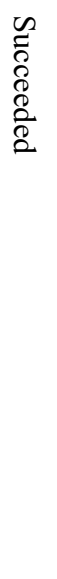 & 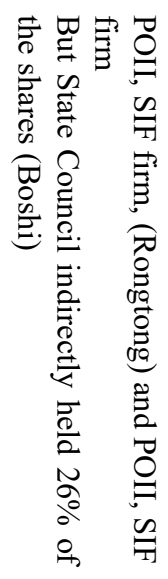 & 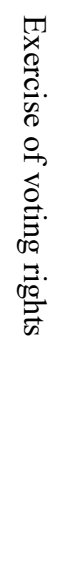 & 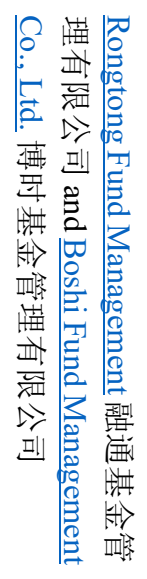 & 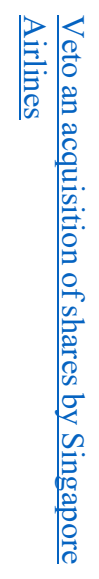 & 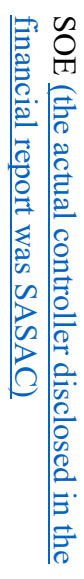 & 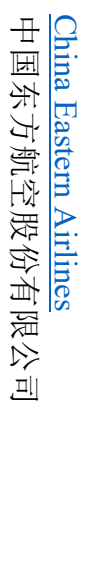 & & $\infty$ \\
\hline 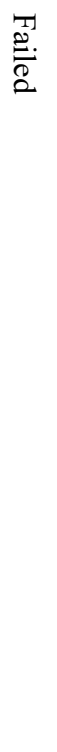 & 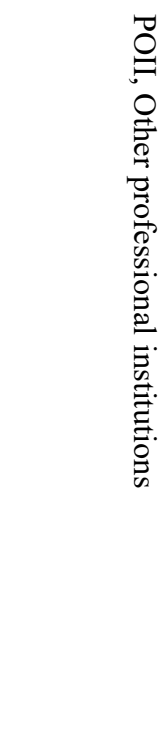 & 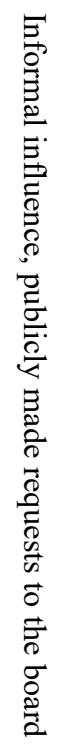 & 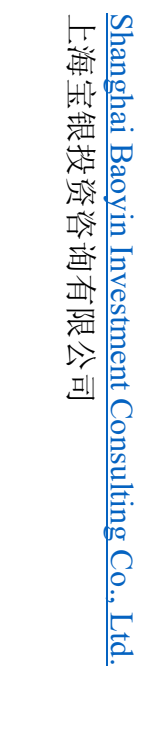 & 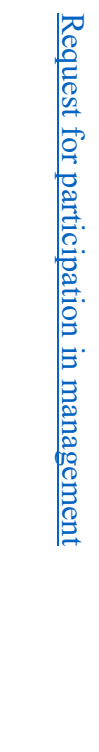 & ర్ & 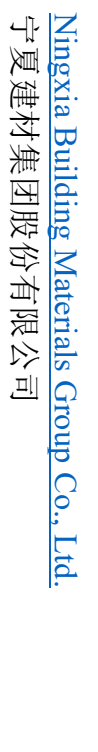 & & 0 \\
\hline 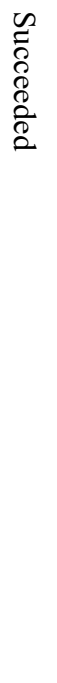 & 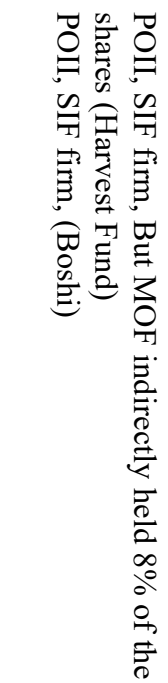 & 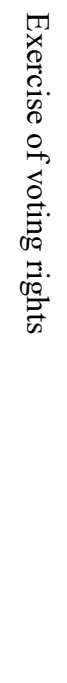 & 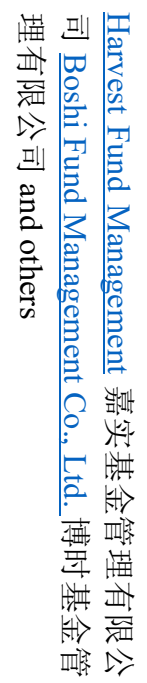 & 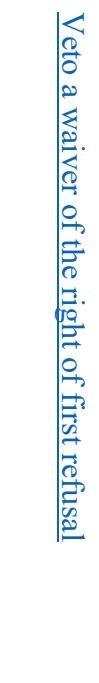 & 유 & 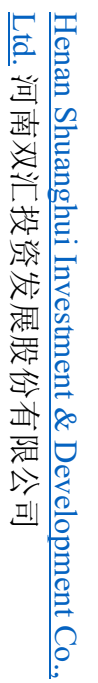 & $\begin{array}{l}\tilde{O} \\
0\end{array}$ & $\widetilde{0}$ \\
\hline
\end{tabular}




\begin{tabular}{|c|c|c|c|c|c|c|c|c|}
\hline 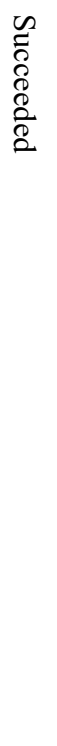 & 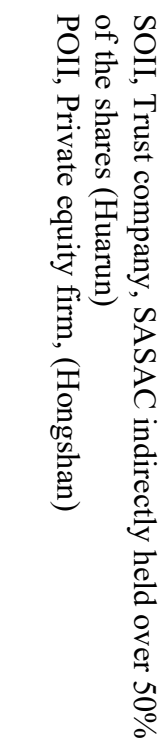 & 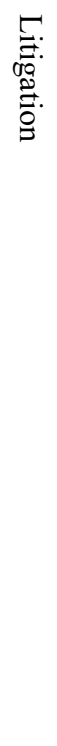 & 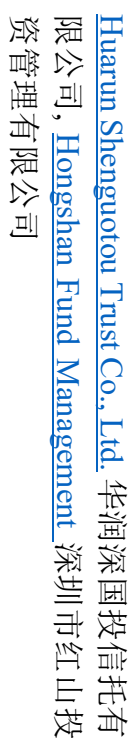 & 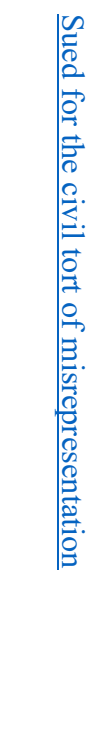 & 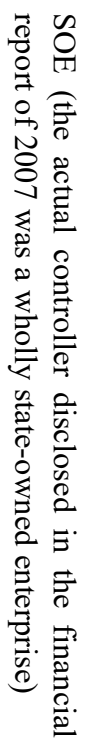 & 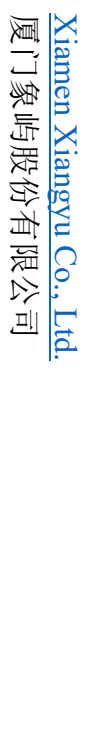 & $\stackrel{N}{\varrho}$ & $\Xi$ \\
\hline 总. & 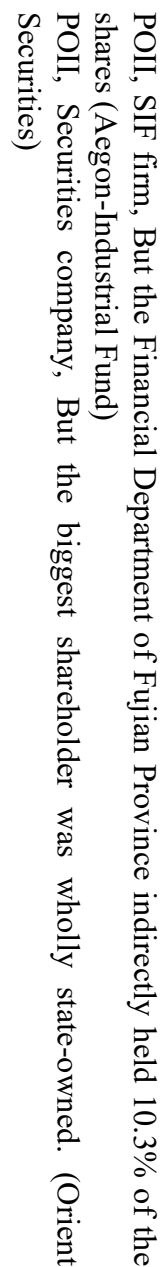 & 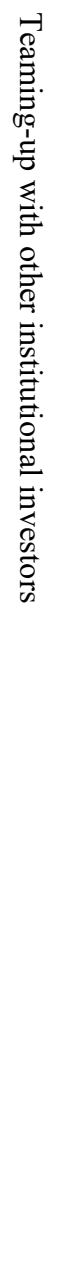 & 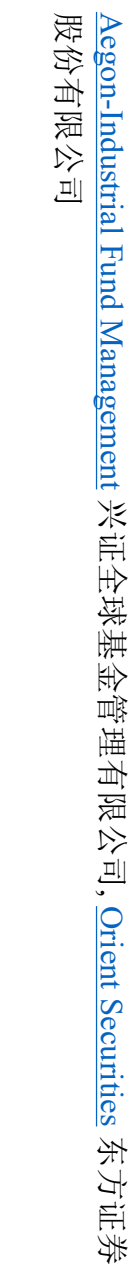 & 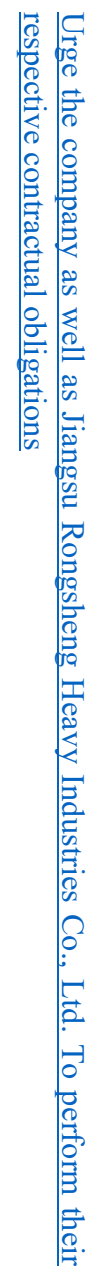 & 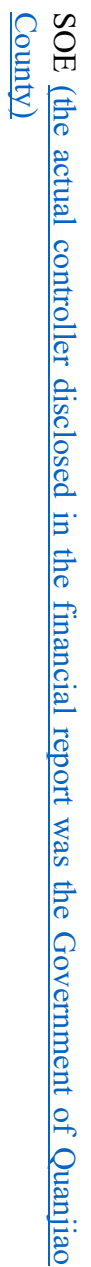 & 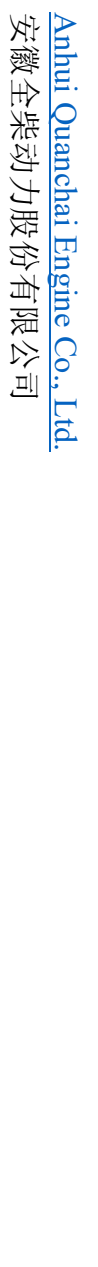 & & $\bar{N}$ \\
\hline
\end{tabular}




\begin{tabular}{|c|c|c|c|c|c|c|c|c|}
\hline 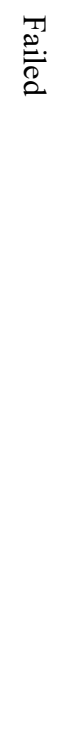 & 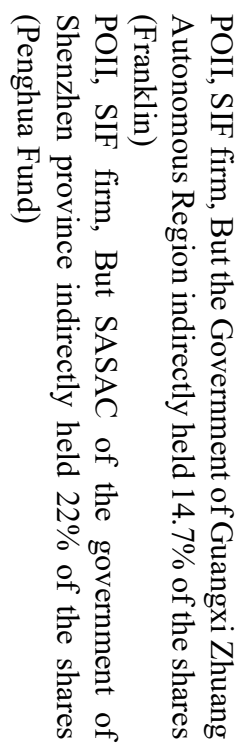 & 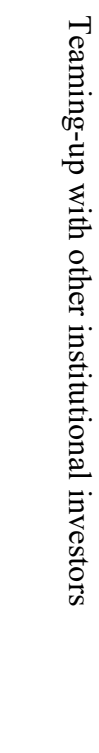 & 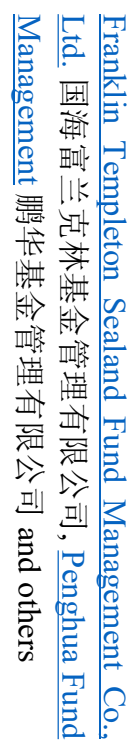 & 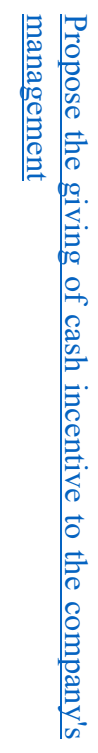 & $\stackrel{5}{0}$ & 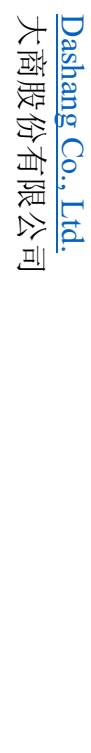 & & $\bar{\omega}$ \\
\hline 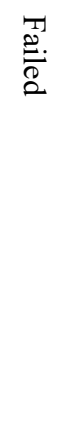 & 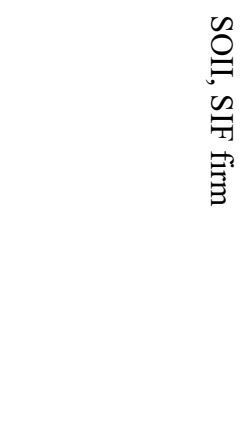 & 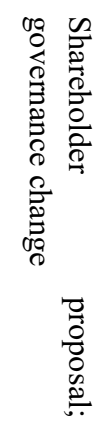 & 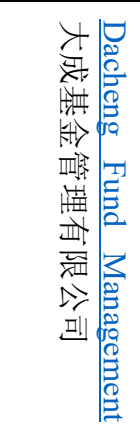 & 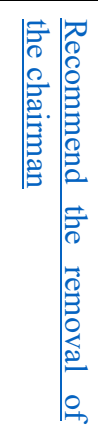 & อొ & 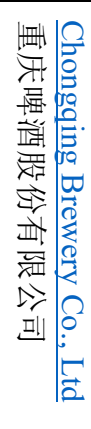 & $\underset{N}{\stackrel{N}{N}}$ & $\bar{A}$ \\
\hline 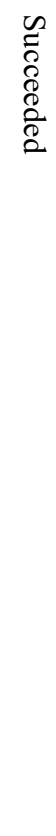 & 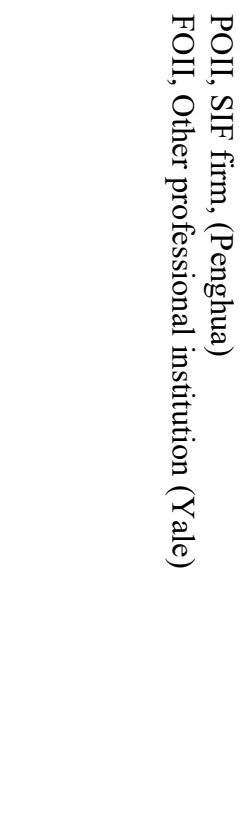 & 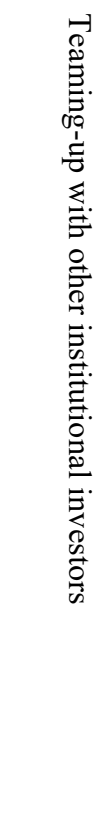 & 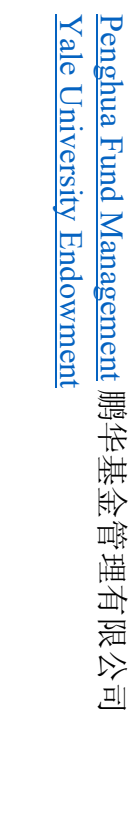 & 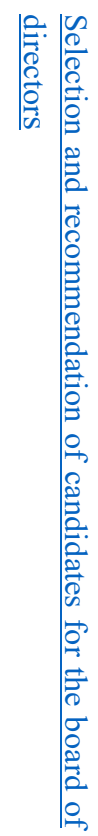 & 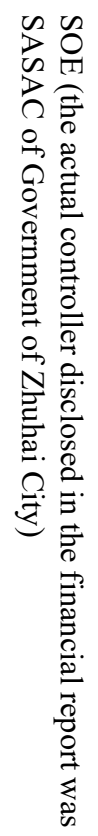 & 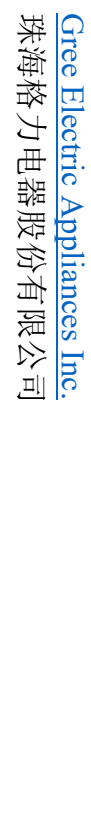 & & $\bar{u}$ \\
\hline
\end{tabular}




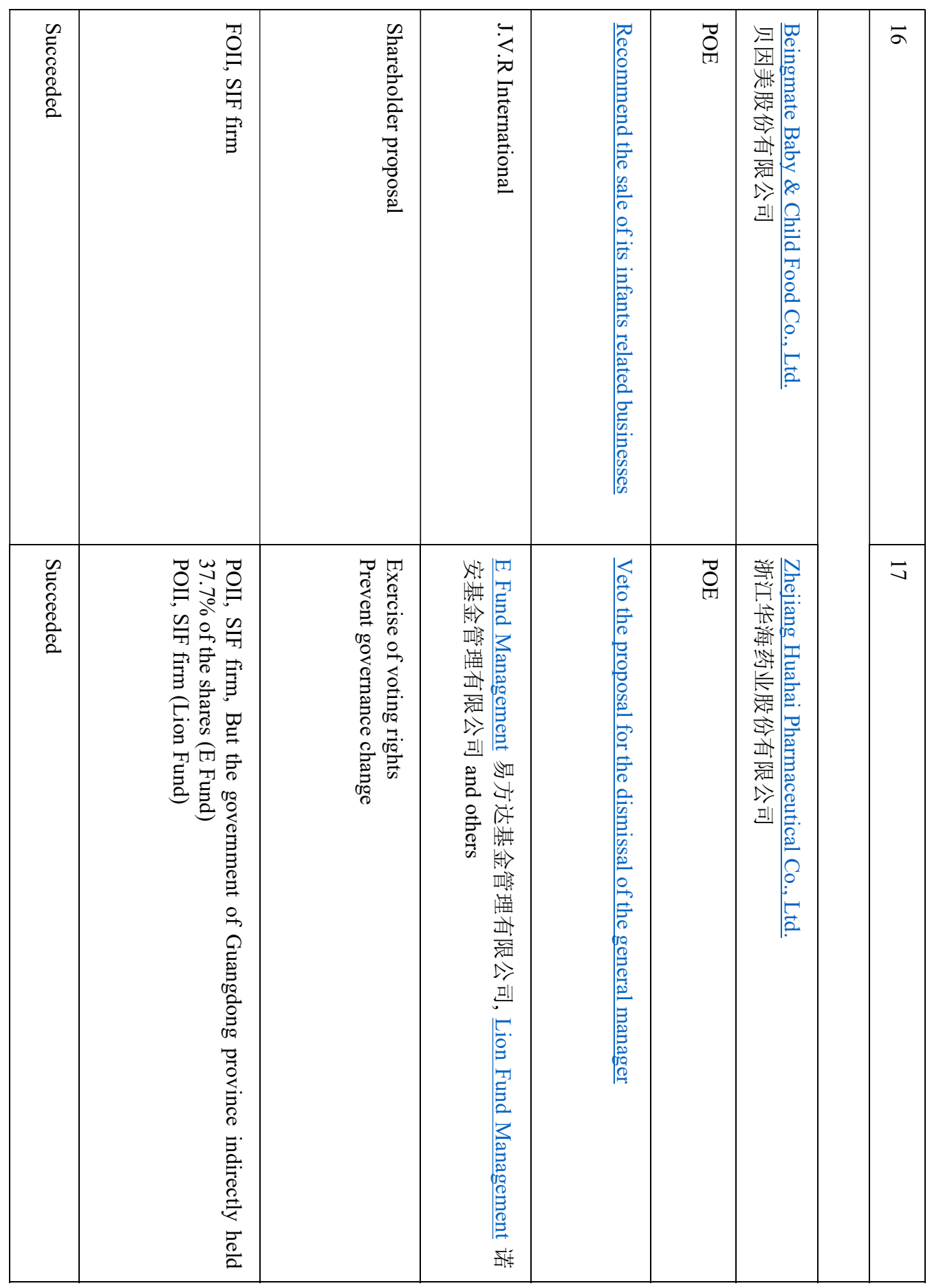




\begin{tabular}{|c|c|c|c|c|c|c|c|c|}
\hline 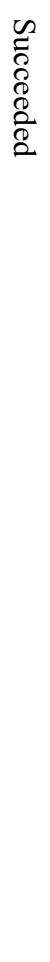 & 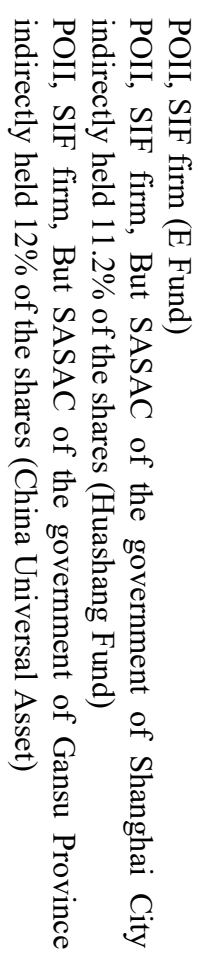 & 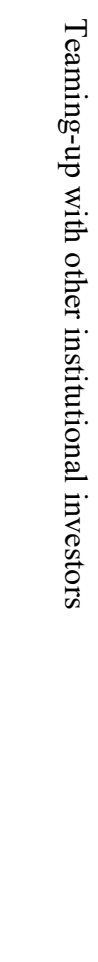 & 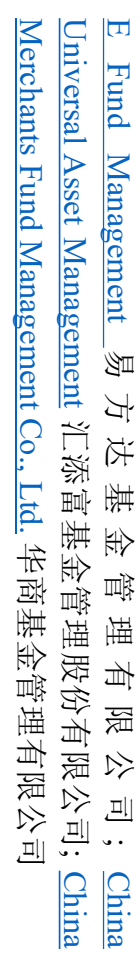 & 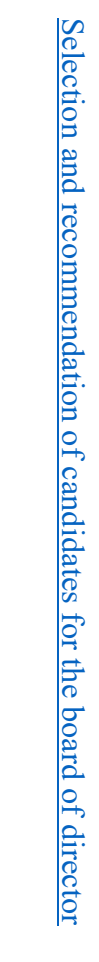 & $\stackrel{0}{0}$ & 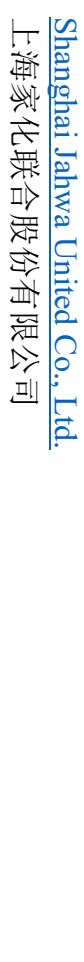 & $\underset{\omega}{\stackrel{N}{ٍ}}$ & $\infty$ \\
\hline 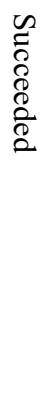 & 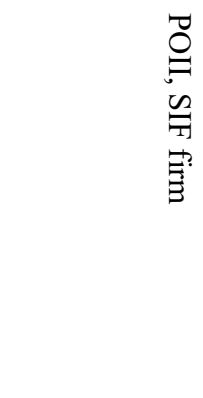 & 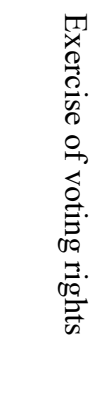 & 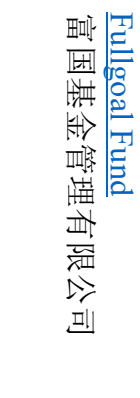 & 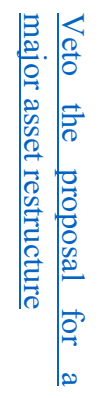 & $\overrightarrow{0}$ & 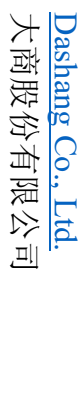 & & $\varpi$ \\
\hline 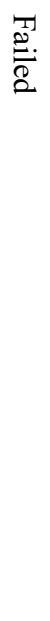 & 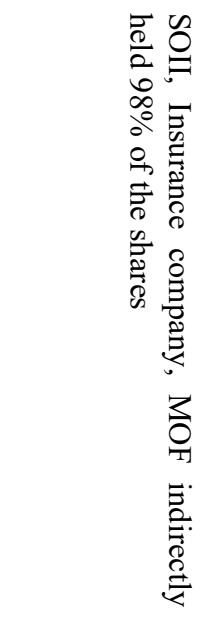 & 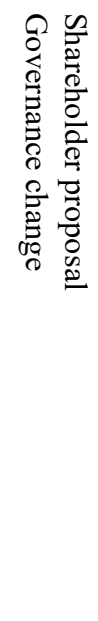 & 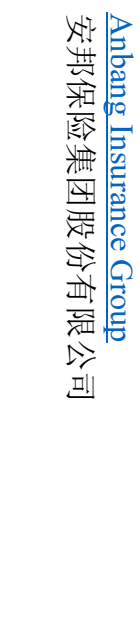 & 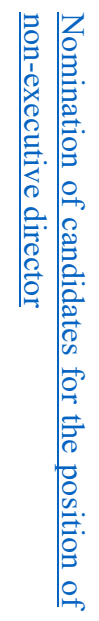 & 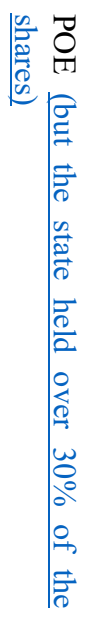 & 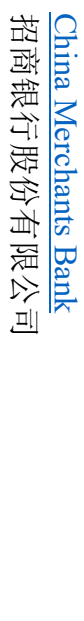 & & $\tilde{o}$ \\
\hline
\end{tabular}




\begin{tabular}{|c|c|c|c|c|c|c|c|c|}
\hline 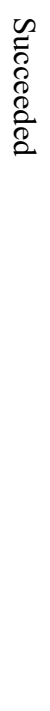 & 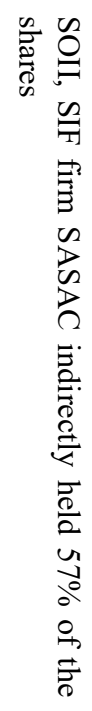 & 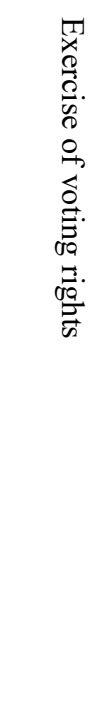 & 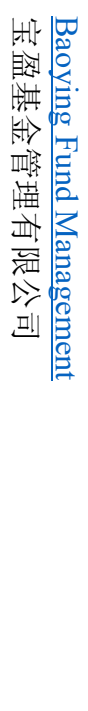 & 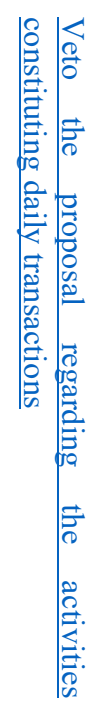 & 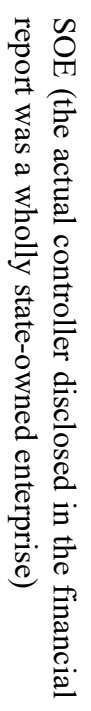 & 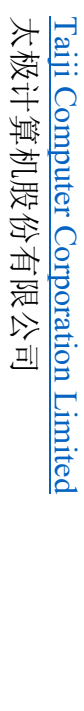 & $\underset{\perp}{\stackrel{D}{O}}$ & $\simeq$ \\
\hline 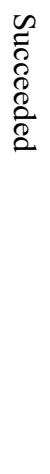 & 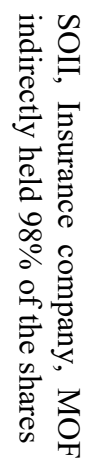 & 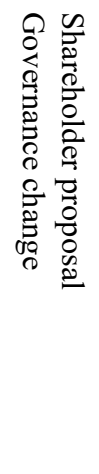 & 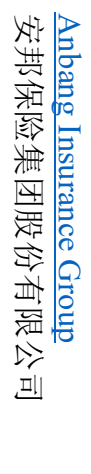 & 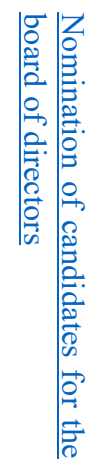 & $\stackrel{0}{0}$ & 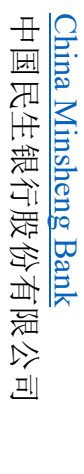 & & $N$ \\
\hline $\begin{array}{l}\frac{1}{3} \\
\stackrel{2}{0} \\
\stackrel{2}{2}\end{array}$ & 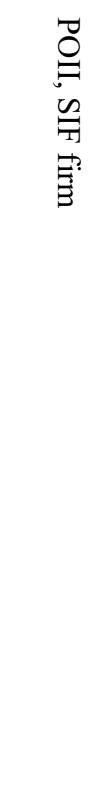 & 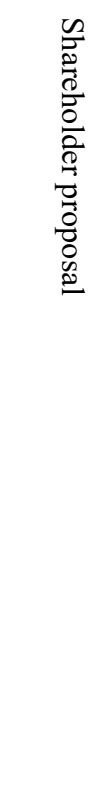 & 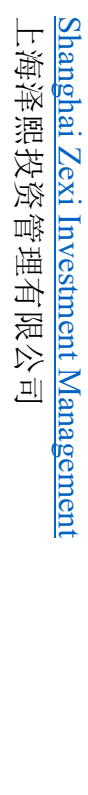 & 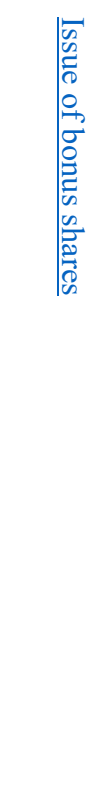 & 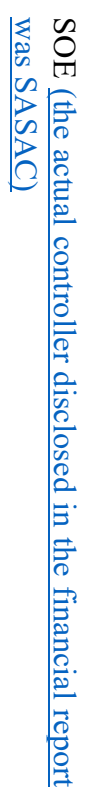 & 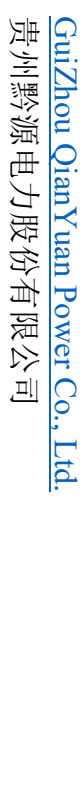 & & $\tilde{\omega}$ \\
\hline
\end{tabular}




\begin{tabular}{|c|c|c|c|c|c|c|c|}
\hline $\begin{array}{l}\text { T. } \\
\overrightarrow{\tilde{D}} \\
\text { : }\end{array}$ & 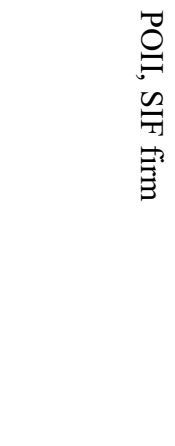 & 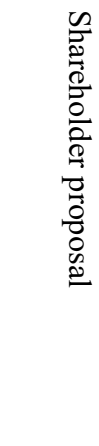 & 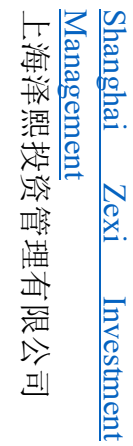 & 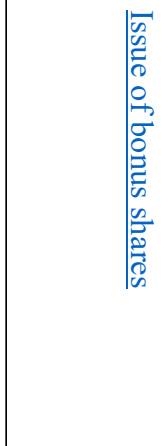 & Oొ & 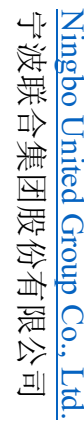 & $\stackrel{N}{\perp}$ \\
\hline 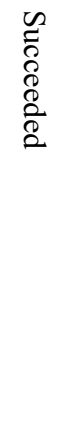 & $\begin{array}{l}\overrightarrow{0} \\
\Xi \\
\mathscr{O} \\
\mathbb{7} \\
\vec{B} \\
\vec{E}\end{array}$ & 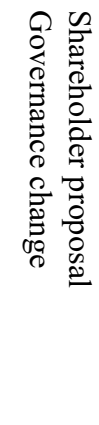 & 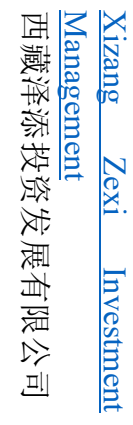 & 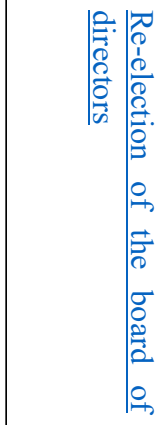 & อ & 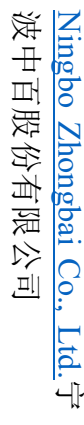 & $\tilde{u}^{\prime}$ \\
\hline 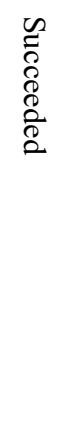 & 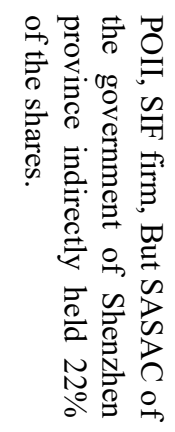 & 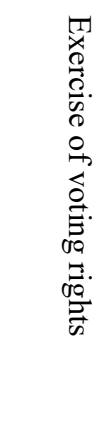 & 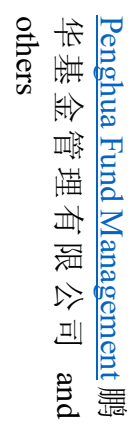 & 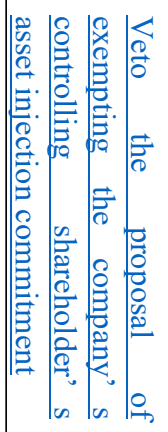 & ర్t & 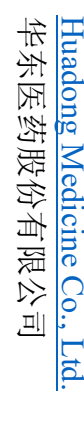 & $\tilde{\sigma}$ \\
\hline $\begin{array}{l}\text { T. } \\
\stackrel{2}{0} \\
\text { : }\end{array}$ & 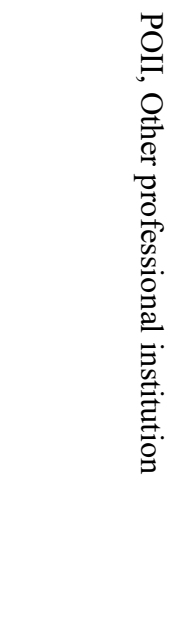 & 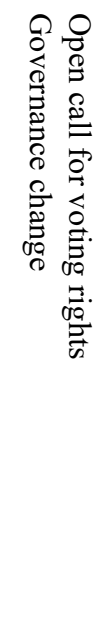 & 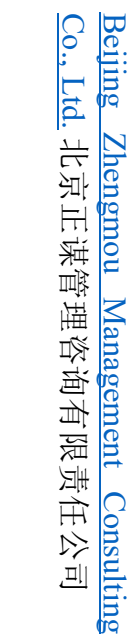 & 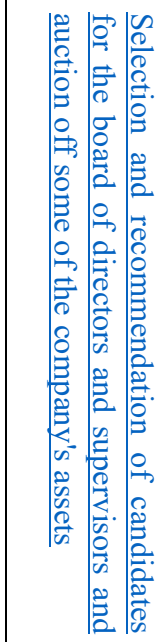 & $\stackrel{\overrightarrow{0}}{\underline{T}}$ & 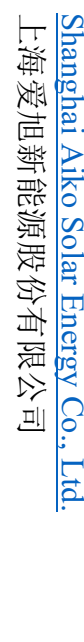 & $\mathrm{N}$ \\
\hline
\end{tabular}




\begin{tabular}{|c|c|c|c|c|c|c|c|c|}
\hline 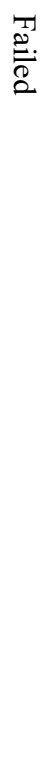 & 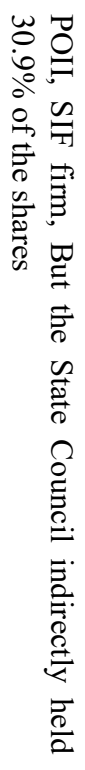 & 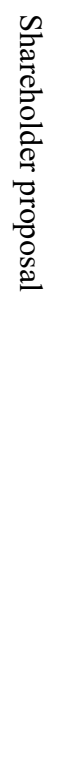 & 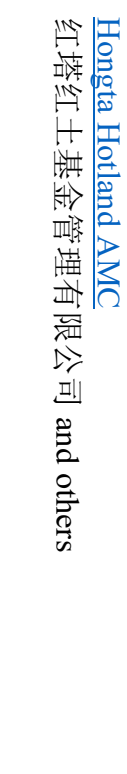 & 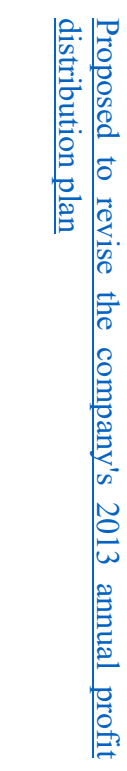 & 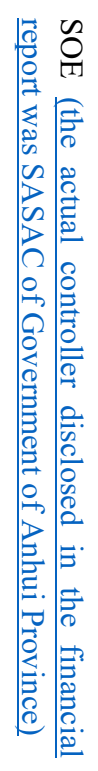 & 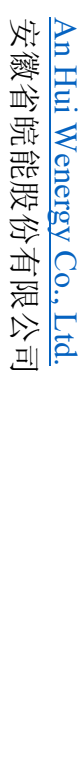 & & $\infty$ \\
\hline 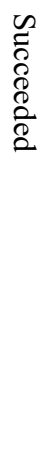 & & 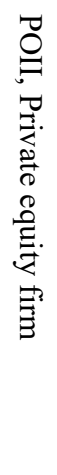 & 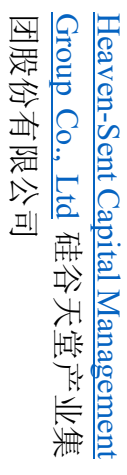 & 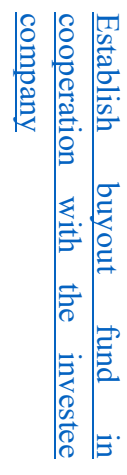 & 虽 & 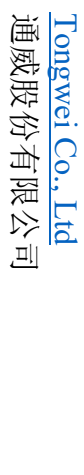 & & $\tilde{\sigma}$ \\
\hline 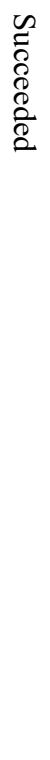 & 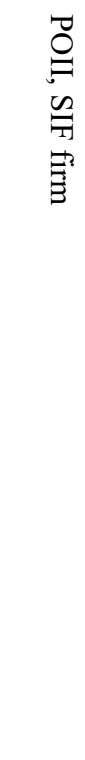 & 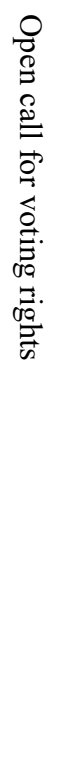 & 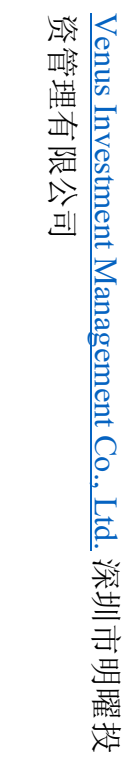 & 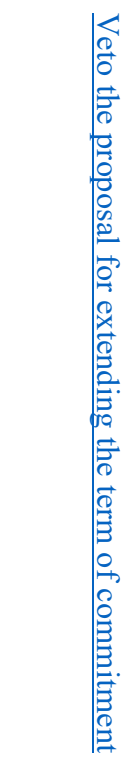 & 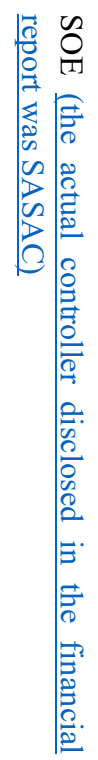 & 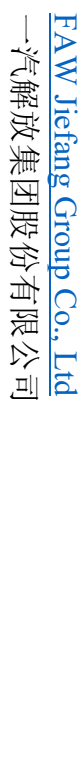 & $\begin{array}{l}\stackrel{N}{\circ} \\
\sigma\end{array}$ & $\stackrel{\omega}{\sigma}$ \\
\hline
\end{tabular}




\begin{tabular}{|c|c|c|c|c|c|c|c|}
\hline $\begin{array}{l}\text { T. } \\
\stackrel{2}{\stackrel{D}{D}} \\
\stackrel{2}{2}\end{array}$ & 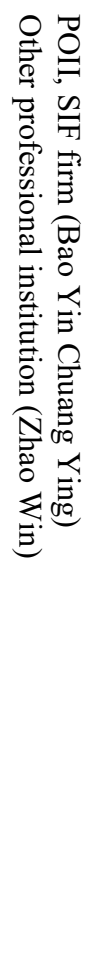 & 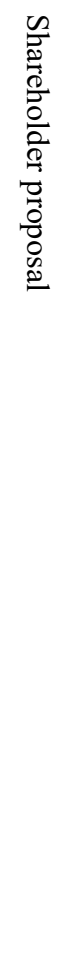 & 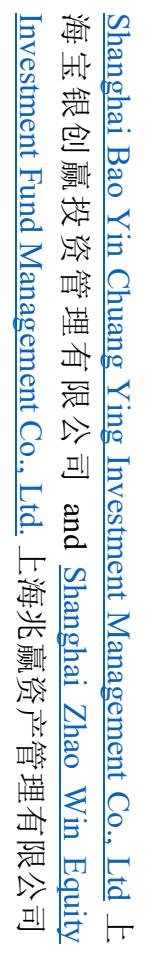 & 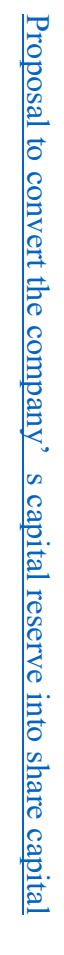 & 可 & 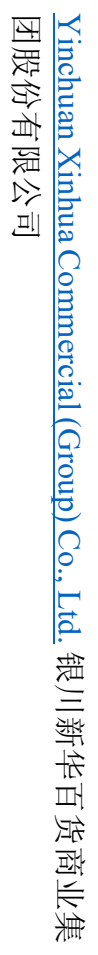 & $\underline{\omega}$ \\
\hline 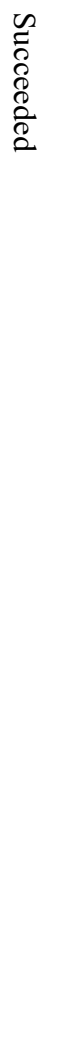 & 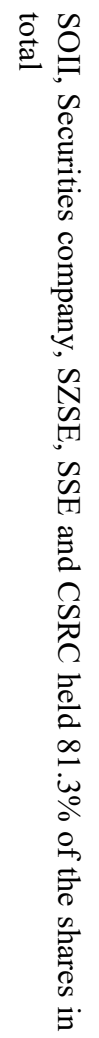 & 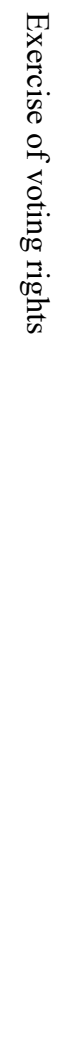 & 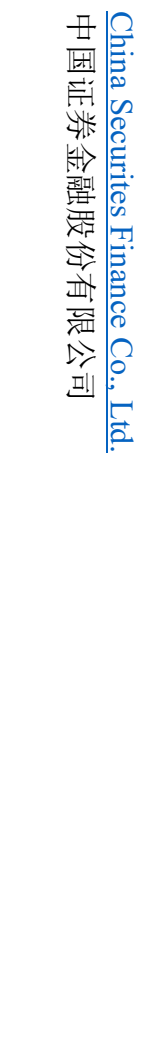 & 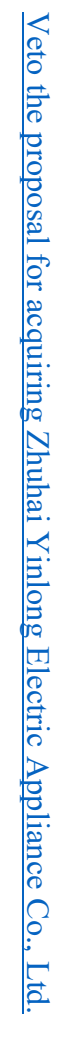 & 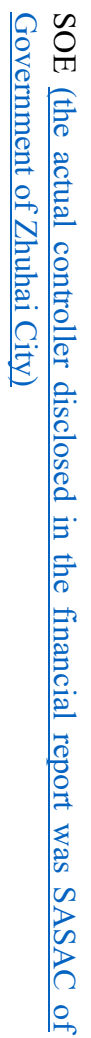 & 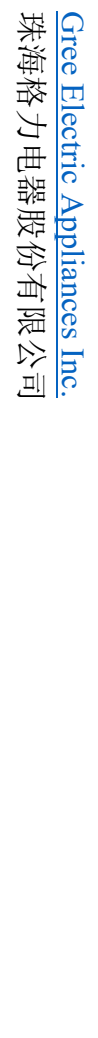 & $\underset{N}{\omega}$ \\
\hline
\end{tabular}




\begin{tabular}{|c|c|c|c|c|c|c|c|c|}
\hline 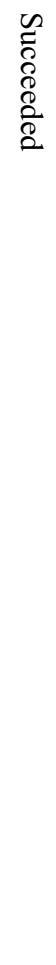 & 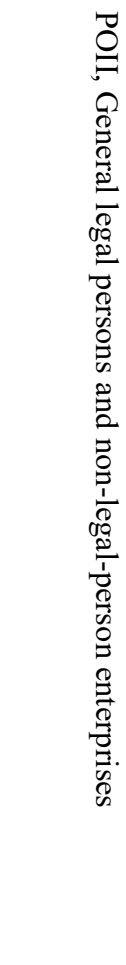 & $\begin{array}{l}\Omega \\
0 \\
0 \\
0 \\
0 \\
0 \\
0 \\
\stackrel{0}{0} \\
0 \\
0 \\
0 \\
0 \\
0 \\
0 \\
0 \\
0 \\
0 \\
0 \\
0\end{array}$ & 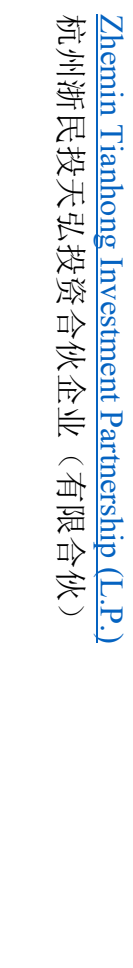 & 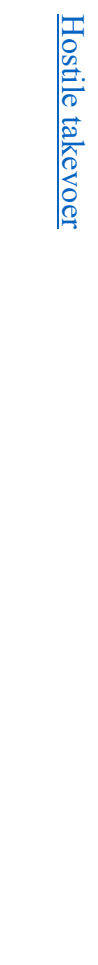 & $\stackrel{0}{0}$ & 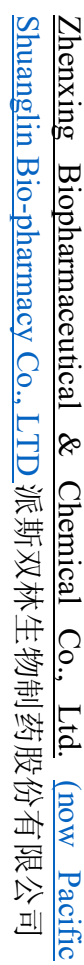 & 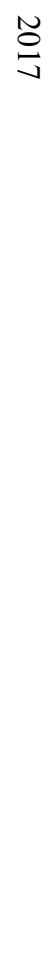 & $\underset{\omega}{\omega}$ \\
\hline 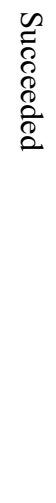 & 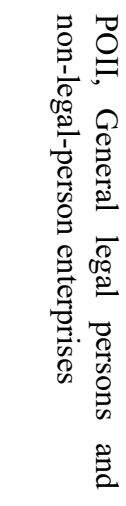 & 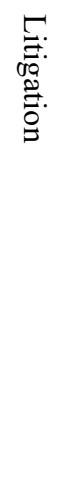 & 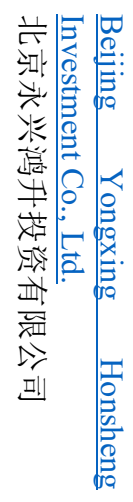 & 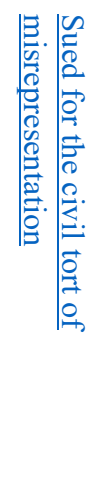 & $\underset{\mathrm{O}}{\mathrm{O}}$ & 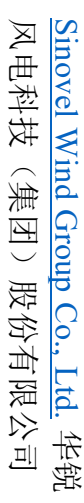 & & $\underset{\perp}{\omega}$ \\
\hline 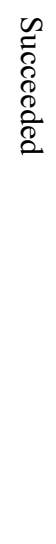 & 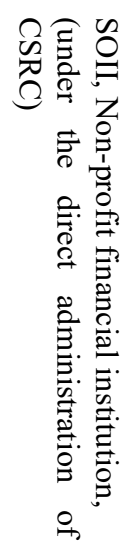 & 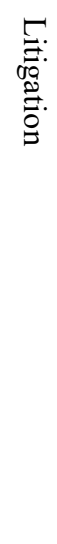 & 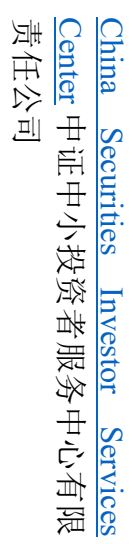 & 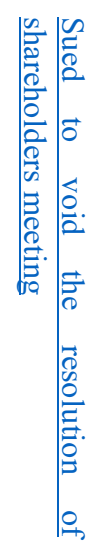 & 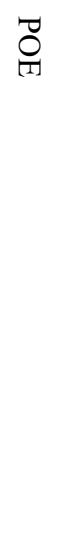 & 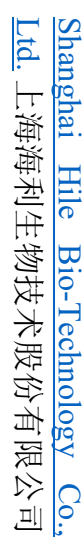 & & $w_{u}^{w}$ \\
\hline
\end{tabular}




\begin{tabular}{|c|c|c|c|c|c|c|c|c|}
\hline 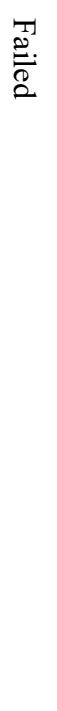 & 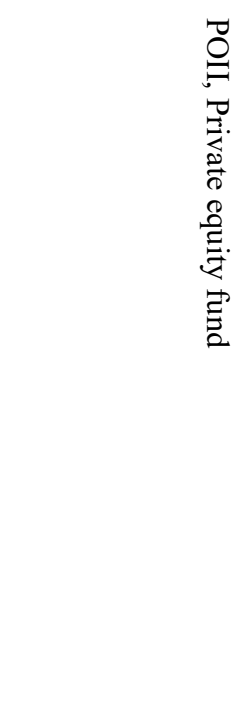 & 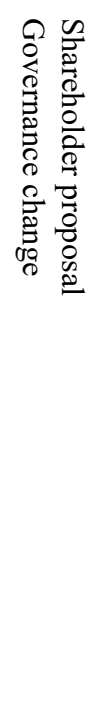 & 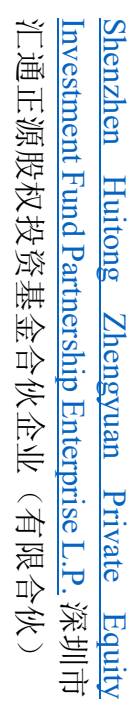 & 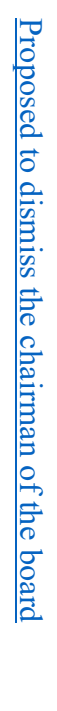 & $\stackrel{0}{0}$ & 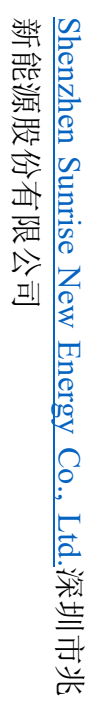 & $\frac{N}{0}$ & $\tilde{\sigma}$ \\
\hline 范 & 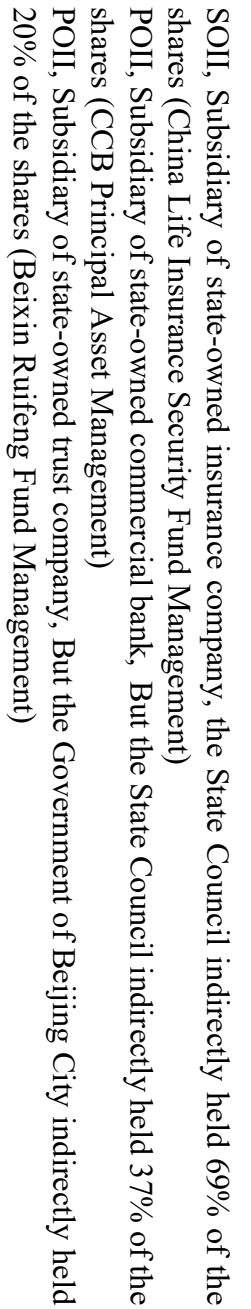 & 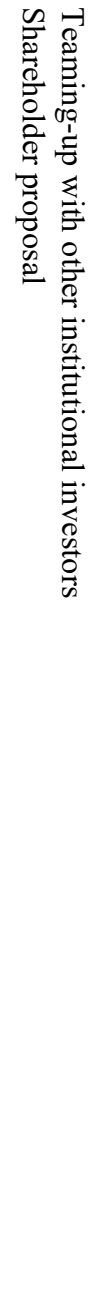 & 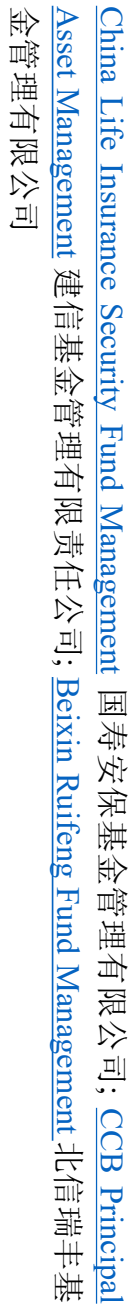 & 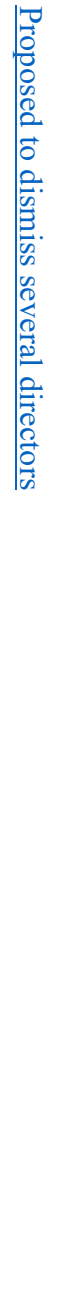 & Oొ & 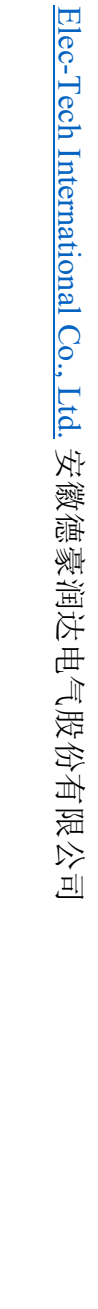 & & $\underline{w}$ \\
\hline
\end{tabular}




\begin{tabular}{|c|c|c|c|c|c|c|c|c|}
\hline 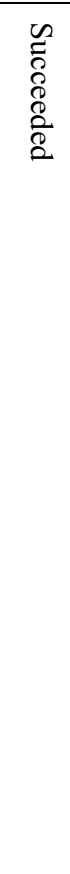 & 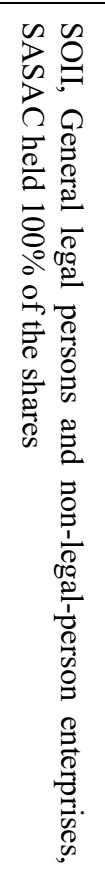 & 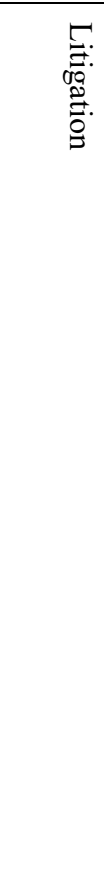 & 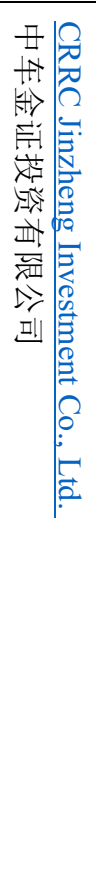 & 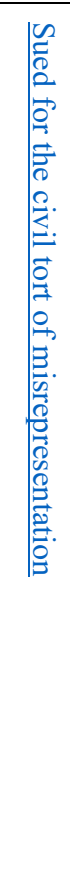 & $\underset{\mathrm{O}}{\overrightarrow{\mathrm{T}}}$ & 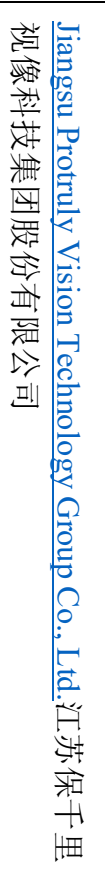 & & $\omega_{\infty}$ \\
\hline $\begin{array}{l}n \\
\overline{0} \\
\text { D. } \\
\text { o. } \\
\text { o. }\end{array}$ & 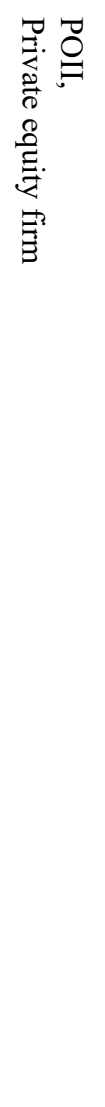 & 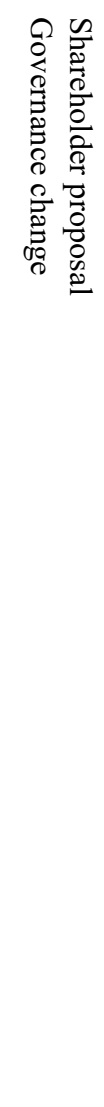 & 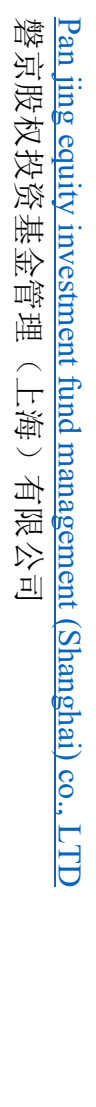 & 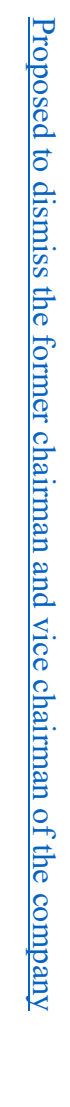 & 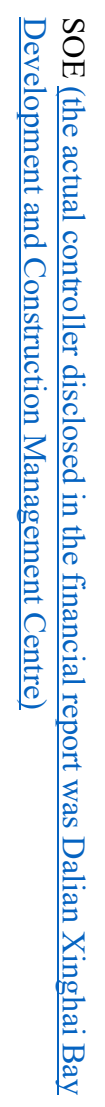 & 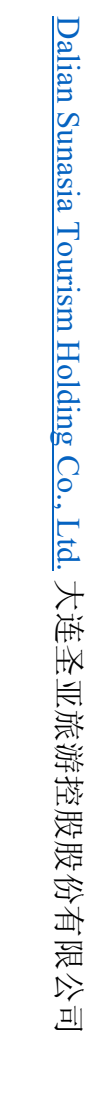 & $\begin{array}{l}\tilde{\tilde{O}} \\
\text { }\end{array}$ & డ్ \\
\hline
\end{tabular}




\begin{tabular}{|c|c|c|c|c|c|c|c|c|}
\hline $\begin{array}{l}\frac{T}{2} \\
\stackrel{2}{0} \\
\stackrel{2}{0}\end{array}$ & 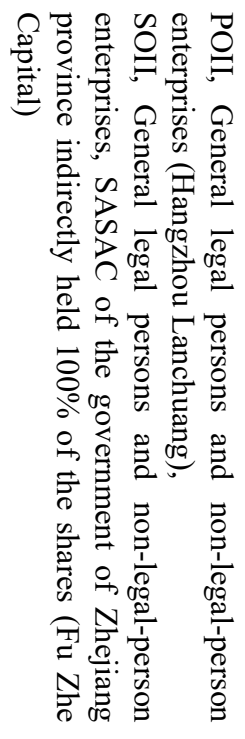 & 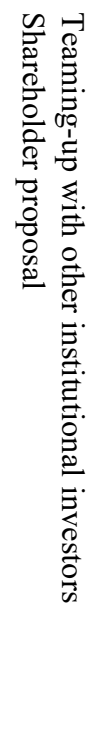 & 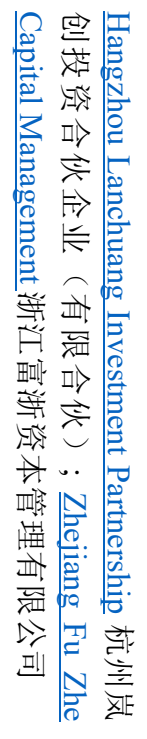 & 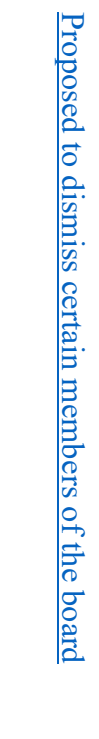 & o & 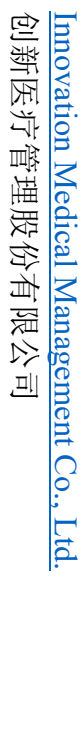 & 芩 & b \\
\hline 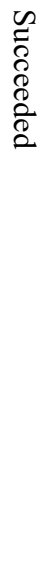 & 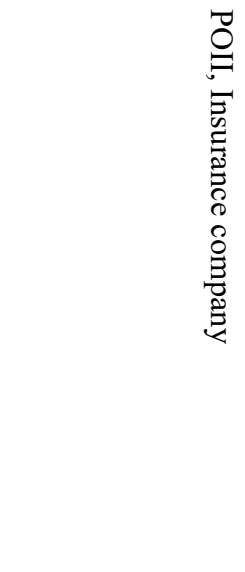 & 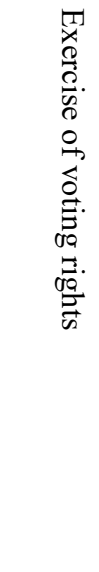 & 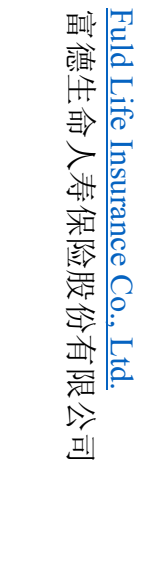 & 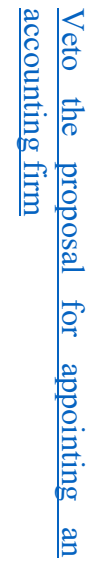 & 恿 & 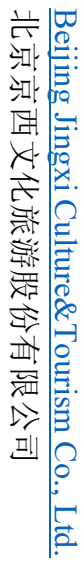 & & \pm \\
\hline $\begin{array}{l}\frac{T}{2} \\
\stackrel{2}{2}\end{array}$ & 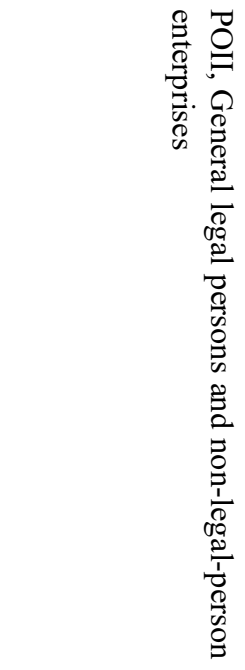 & 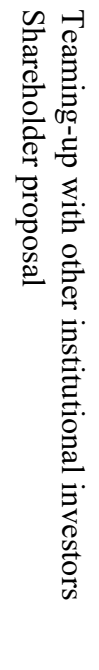 & 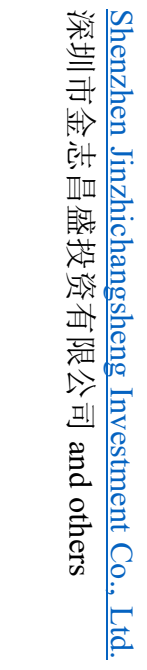 & 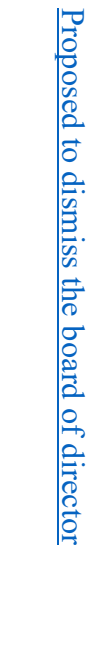 & $\stackrel{0}{0}$ & 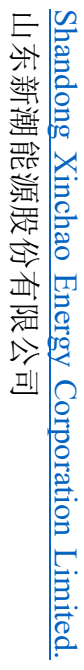 & & $\hat{N}$ \\
\hline
\end{tabular}




\begin{tabular}{|c|c|c|c|c|c|c|c|}
\hline 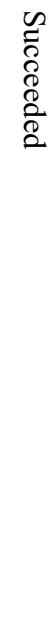 & 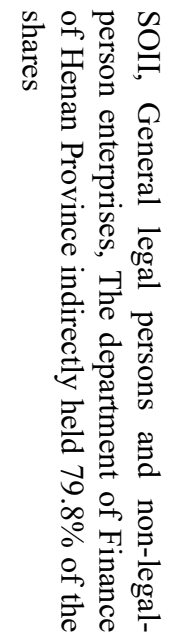 & 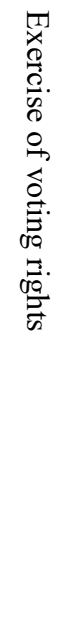 & 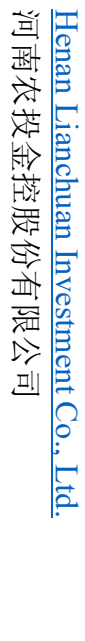 & 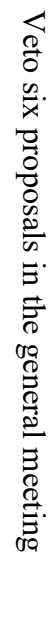 & ô & 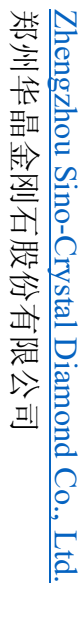 & $\stackrel{t}{\omega}$ \\
\hline
\end{tabular}

